\title{
Att leva med en kropp som värker \\ samtal med fysioterapeuten
}

\author{
Maria Afrell
}

Division of Community Medicine, General Practice

Department of Medical and Health Sciences Linköping University, Sweden

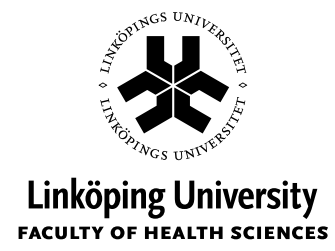

Linköping 2014 
(C) Maria Afrell 2014

Cover picture/illustration: Johanna Övling

Published article has been reprinted with the permission of the copyright holder.

Printed in Sweden by LiU-Tryck, Linköping, Sweden, 2014

ISBN 978-91-7519-363-2

ISSN 0345-00087 


\section{INNEHÅLL}

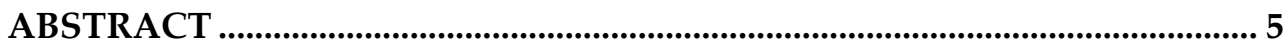

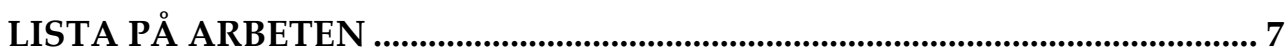

FÖRKORTNINGAR OCH FÖRTYDLIGANDEN .............................................. 8

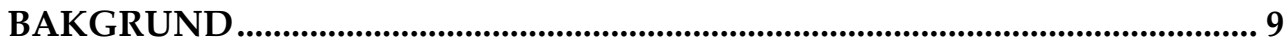

Bakgrunden till projektet....................................................................... 9

Långvarig benign muskuloskeletal smärta .................................................... 9

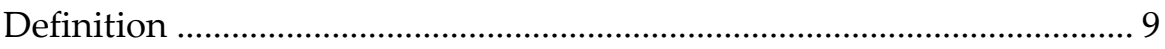

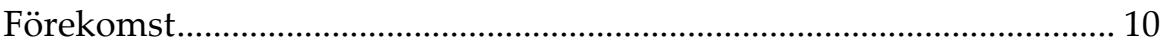

Smärtans sammanhang och orsaker - den biopsykosociala modellen ... 10

Att leva med långvarig smärta.......................................................................... 12

Fysioterapi vid långvarig smärta ..................................................................... 14

Behandlingen som den ser ut idag ......................................................... 14

Helhetsinriktad fysioterapi …………………….................................. 15

Implikationer för avhandlingsarbetet ............................................................... 16

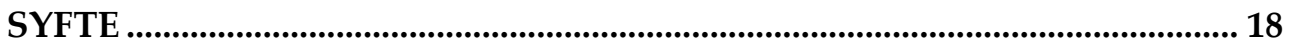

Övergripande syfte ............................................................................................... 18

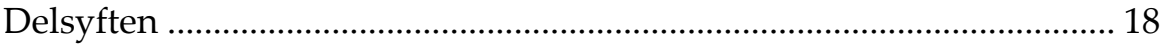

TEORETISK RAM ............................................................................................. 20

Ett förhållningssätt för fysioterapeuter i första linjen ..................................... 20

Kroppen ur ett fenomenologiskt perspektiv ................................................... 21

Det biografiska perspektivet .................................................................... 22

Fysioterapeutisk forskning som bygger på "den levda kroppen" ............ 24

Interaktionen i det fysioterapeutiska mötet...................................................... 26

Sammanfattning av teoretiska utgångspunkter ............................................... 29

MATERIAL OCH METOD .................................................................................... 31

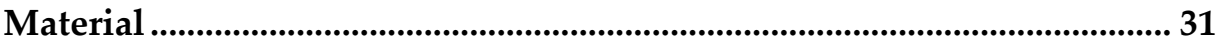




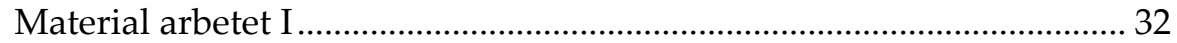

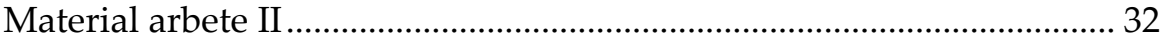

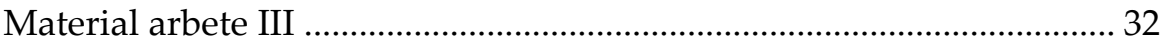

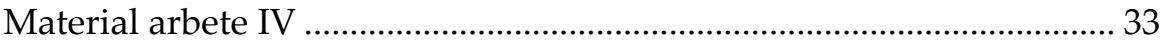

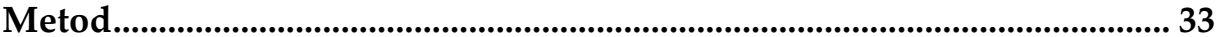

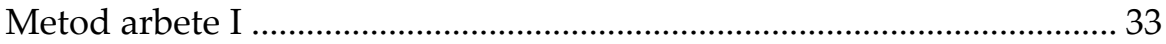

Metod arbete II ................................................................................. 36

Metod arbete III.................................................................................. 41

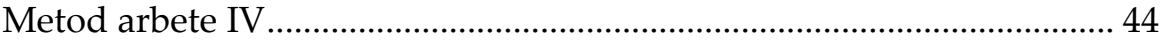

ETIK

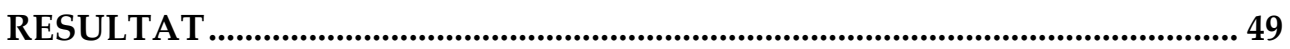

Resultat arbete I och III Att leva med en kropp som värker och att utifrån nyckelfrågor samtala om den värkande kroppen ............................. 50

Fyra begrepp - aspekter av kroppsupplevelse ....................................... 50

Typologierna - referensram för tolkning av förhållningssätt.................. 53

Resultat arbete II: "Vi fick hela historien på en gång"; fysioterapeuters användning av nyckelfrågor i mötet med patienter med långvarig

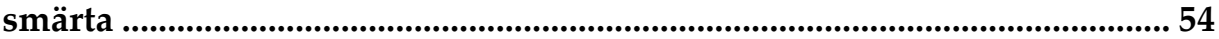

Resultat arbete IV: Att förbättra samspelet mellan fysioterapeuten och patienten med långvarig smärta................................................................... 56

Resultatets kvalitativa del................................................................ 57

Resultat av kvantifiering av kvalitativa koder .......................................... 59

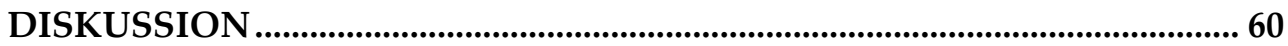

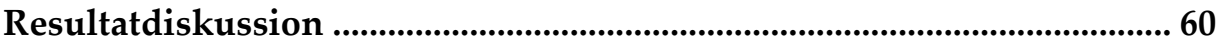

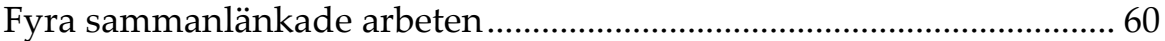

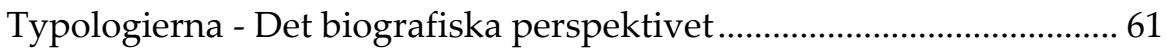

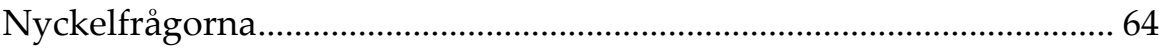

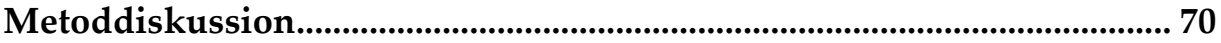

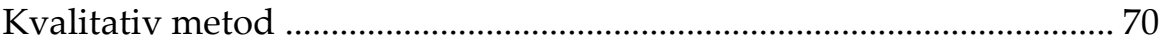

Kvalitativ innehållsanalys med kvantifiering av koder............................ 71

Arbetets begränsningar ...................................................................................... 73

Implikationer för fortsatt forskning och utbildning ..................................... 73 


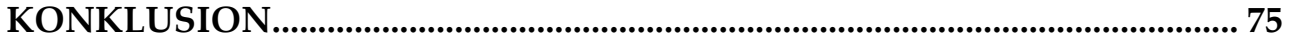

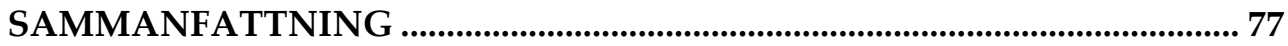

TACK

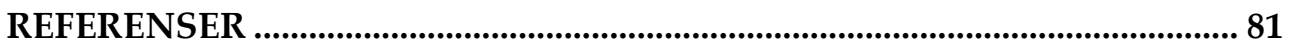





\section{ABSTRACT}

Background and aim: Physiotherapists in primary care meet, assess and treat patients with long-standing benign musculoskeletal pain. As a clinical condition, long-standing pain is quite common but nonetheless it is quite complex. The aim of this thesis has been, from a bodily existential perspective, to investigate and conceptualise the experience of living with long-standing benign musculoskeletal pain, and from there, to work out a method for conversation and assessment within non-specialised physiotherapy

Methods: Our first study was an interview study where we applied a phenomenological approach and investigated the ways individuals suffering from long-standing pain experienced their body and their illness. Four aspects of body experience were described, and based on these aspects, four typologies of attitudes to pain were distinguished. In the second study, we made two group interviews with six physiotherapists about their experiences of using, in their clinical work, questions from the interview guide in study I that had given particularly rich responses. Transcripts were analysed using phenomenography. In the third study, patients' verbal responses to the key questions, directed to them by physiotherapists in clinical situations, were investigated, and the four aspects of body experience from study I formed the concepts of a deductive analysis. In study IV, finally, the key questions and typologies were tried by a larger group (31), and their experiences and the possible applicability of the method were studied by qualitative content analysis combined with the counting of codes.

Results: We created four typologies of attitudes to long-standing pain: "Surrendering to one's fate", "Accepting by an active process of change", "Balancing between hope and resignation" and "Rejecting the body". These typologies, in turn, were based on four aspects of body experience: "The body as an aspect of identity". "Body reliance", "Body awareness", and "Ways of understanding pain". In study II, by the aid of key questions, patient and physiotherapist managed to have a conversation on bodily existential matters. The physiotherapist learnt to know the patient as a person, a process appeared to be initiated in the patient, and their relation changed. The patient was willing to talk about her body in pain, and had the words to do this. In study III, the key questions opened ways to reflections on body, existence, and biography. 
The four aspects of body experience were central to the patients' descriptions. In study IV, the participating physiotherapists reported by large positive experiences from applying key questions and typologies. The patients reflected, emotions were evoked, and the relation and the communication often improved. The typologies helped in giving a comprehensive perspective of the patient's problem, and to grasp where in the process of rehabilitation the patient was to be found.

Conclusions: The method, seven key questions combined with the tentative frame of interpretation of the answers, seemed to be easily applied by interested physiotherapists in non-specialised practice. The application of the method addresses the need of developing the professional role of the physiotherapist. The challenge is to face the whole person, who is her lived body as well as her identity crisis, carried by emotions such as grief and anger. This may inspire the use of the full potential of the physiotherapist's professional role in the clinical encounter. 


\section{LISTA PÅ ARBETEN}

Den här avhandlingen är baserad på följande arbeten, vilka kommer att bli refererade till med romerska siffror:

I. Afrell M, Biguet G, Rudebeck CE. Living with a body in pain - between acceptance and denial. Scand J Caring Sci; 2007; 21; 291-296

II. Afrell M, Rudebeck CE. 'We got the whole story all at once': physiotherapists' use of key questions when meeting patients with longstanding. Pain Scand J Caring Sci; 2010; 24; 281-289

III. Afrell M, Rudebeck CE. Telling about long-lasting pain - the role of key questions in physiotherapy encounters (Manuscript).

IV. Afrell M, Brudin L. Rudebeck CE. Improving the interaction between the physiotherapist and the patient with long-lasting pain (Manuscript). 


\title{
FÖRKORTNINGAR OCH FÖRTYDLIGANDEN
}

\author{
Ftp \\ B-BAT \\ Fysioterapeut \\ NPMP \\ Basic Body Awareness Therapy \\ EPP \\ Norwegian Psychomotor Physiotherapy \\ EU \\ Empirical Phenomenological Method \\ IU \\ Empathic Understanding, empatisk förståelse \\ MU \\ Interpretive Understanding, tolkande förståelse \\ SBU \\ Meaning Unit, meningsbärande enhet \\ FMS \\ Statens Beredning för Medicinsk Utveckling \\ KBT \\ Fibromyalgi Syndrom \\ CBT \\ Kognitiv Beteendeterapi \\ MI \\ Cognitive Behavioral Therapy \\ Motivational Interviewing, motiverande samtal
}

Self-efficacy Ungefärlig svensk översättning är en individs tilltro till sin egen förmåga. Denna förmåga kan göra skillnad i hur en individ hanterar en situation. Begreppet myntades av Bandura (1) och används bl.a. inom rehabiliteringsforskning. I detta arbete kommer self-efficacy att användas.

Översättningar av begrepp och resultat till svenska har gjorts av avhandlingens författare, Maria Afrell, om inget annat anges. 


\section{BAKGRUND}

\section{Bakgrunden till projektet}

Mitt forskningsfält utgår från mitt arbete som fysioterapeut där jag möter patienter med långvarig benign muskuloskeletal smärta. Perspektivet är kroppsligt existentiellt, vilket innebär att jag undersöker hur det är att leva med en kropp som värker mer än att söka orsakerna till smärtan.

Intresset för forskningsområdet växte fram ur den kliniska erfarenheten, i möten med patienter som hade smärt- och spänningsproblem. Det var tydligt hur patienternas psykiska mående, livserfarenhet och sociala situation påverkade upplevelsen av smärta, men också hur deras förmåga och strategier för att hantera svårigheter med den värkande kroppen inverkade på deras liv. Som fysioterapeut handlade det om att förstå hur patienter med långvariga smärt- och spänningsproblem uppfattade och erfor sin kropp och sina besvär. Med kunskap om detta skulle det kunna bli möjligt att anpassa den fysioterapeutiska behandlingen till individens behov. Min erfarenhet var att det tog lång tid att finna fram till en framgångsrik behandlingsväg. Forskningsfrågan växte således fram både ur behovet av en teoretisk fördjupning och av att finna praktiska vägar att bättre hjälpa individer med långvarig smärta.

\section{Långvarig benign muskuloskeletal smärta}

\section{Definition}

International Association for the Study of Pain (IASP) definierar smärta som "... en obehaglig sensorisk och känslomässig upplevelse förenad med vävnadsskada eller hotande vävnadsskada eller beskriven i termer av sådan skada"(2). Upplevelse av smärta är en subjektiv företeelse med ytterligare ett antal dimensioner - t.ex. intensitet, kvalitet, tidsförlopp och vilken personlig betydelse som smärtan har (3). Med andra ord, smärta upplevs unikt av varje 
individ och kan bara bedömas indirekt av andra. Med långvarig smärta menas att smärtan pågått en viss tid, vanligen anges en gräns på mer än 3 månader och att den ska vara ihållande eller intermittent $(4,5)$.

\section{Förekomst}

Långvarig smärta är ett vanligt tillstånd. Muskuloskeletala smärtor utgör huvuddelen av de långvariga smärttillstånden $(5,6)$. Befolkningsstudier visar att frekvensen av långvarig smärta i en normalpopulation är mellan 40 och 55 $\%$, minst en fjärdedel av dessa har svårigheter att leva med sin smärta och har behov av insatser från vården (5).

Förekomst av långvarig generaliserad smärta (smärta spridd i stora delar av kroppen) är 5-10 \% hos kvinnor, vilket är dubbelt så hög frekvens som hos män. Tillstånd i rörelse- och stödjeorganen utgjorde $32 \%$ av det totala antalet sjukskrivningar och $37 \%$ av de totala kostnaderna för sjukskrivningsår 2001 (RFV 2002:2) (5). Även vid psykiska besvär förekommer ofta smärta och en kombination av psykiska besvär och smärta är nog det vanligaste (7). Många med långvarig smärta söker vård, beräkningar som gjorts visar att $20-40 \%$ av besöken i primärvården har varit föranledda av smärta, av dessa är ca hälften långvarig smärta (8). När smärtan väl är etablerad är möjligheterna till smärtfrihet relativt små (9). Mycket tyder på att tidig rehabilitering är av största vikt (5).

Långvarig benign muskuloskeletal smärta kommer i fortsättningen endast benämnas långvarig smärta.

\section{Smärtans sammanhang och orsaker - den biopsykosociala modellen}

1977 publicerade Engel (10) i artikeln " The need for a new medical model" den biopsykosociala modellen som en utmaning till den då förhärskande biomedicinska modellen.

I ett biopsykosocialt perspektiv interagerar tankar, föreställningar, känslor, beteende och sociala sammanhang och biologiska processer. Engels syfte med att lansera den biopsykosociala modellen var inte primärt att lägga till psykiska 
och sociala sjukdomsorsaker till de biologiska, utan att den biopsykosociala helheten skulle bli medicinens självklara referensram vid bedömning av sjukdomar och vid behandling av lidande. För honom var den psykosociala dimensionen lika grundläggande som den biologiska.

Den långvariga smärtan är oftast förknippad med en komplex kombination av risk- och vidmakthållande faktorer samt influeras av och interagerar med olika fysiska, emotionella, psykologiska och sociala faktorer, livshistoria och allmänna hälsotillstånd $(4,11,12)$. Den biopsykosociala modellen har också vunnit stort inflytande inom rehabilitering av annan kronisk sjukdom (13). I det kliniska mötet får den biopsykosociala modellen sin betydelse genom att patientens personliga upplevelse av att leva med smärta lättare kommer fram när den yrkesperson han eller hon talar med har kunskaper om och intresse för problemets alla aspekter.

Trots detta har biomedicinens orsak-verkanmodell fortfarande stort inflytande och den ingår i tillämpningen av den biopsykosociala modellen om än i något mer komplex version, när den biologiskt kartlagda kroppen uppfattas interagera med sitt psykosociala sammanhang. Den psykosociala dimensionen tenderar att bli mer ett tillägg till orsaksförklaringarna än att den förändrar uppfattningarna om hur långvarig smärta kan tolkas. Inom de biomedicinska och biopsykosociala perspektiven har vetenskapen svårt att förklara för patienten varför livet med den värkande kroppen är som det är. I fysioterapeutens fall, menar jag, räcker inte orsaksförklaringarna för att leva sig in och värdera patientens situation. När SBU 2010 bedömde resultat av behandling vid långvarig smärta fann de att varken rent kroppsinriktad eller psykologiskt inriktad behandling eller kombinationen av dem, har några mer påtagliga effekter på smärtan (14).

Detta betyder för den skull självklart inte att den biomedicinska kunskapen är oviktig när det gäller långvarig smärta. Central smärtsensitisering ger ett intressant perspektiv på neurofysiologiska mekanismer som kan medverka vid kronisk smärta och som kan ge nya behandlingsalternativ. Men oaktat att sensitiseringsteorin framstår som klar och pedagogiskt tilltalande lämnar den viktiga frågor kvar i det enskilda fallet. Den säger inte var smärtans utlösande och vidmakthållande omständigheter ytterst finns; om det är i kroppen eller livssammanhanget. Varje medvetandeprocess har sin motsvarighet i kroppsliga processer oberoende av kausalitetsförhållandet. Receptorer som tar emot smärtsignaler har också kontakt med emotionella delar av hjärnan och neurofysiologiskt finns påtagliga likheter mellan socialt och kroppsligt betingad smärta (15). 


\section{Att leva med långvarig smärta}

Forskning har gjorts ur olika perspektiv för att öka kunskapen om hur det är att leva med långvarig smärta. Tillståndet innebär ofta ett stort personligt lidande och påverkar individens hälsorelaterade livskvalitet $(5,11,16,17)$. I jämförelse med de flesta andra medicinska tillstånd skattar personer med långvarig smärta sin livskvalitet lågt (16). IMMPACT-gruppen utförde en serie av studier (18-20) som syftade till att klarlägga detta förhållande. Man ville nå konsensus om väsentliga resultatparametrar inför behandlingsstudier. I en studie i två steg fick först fokusgrupper i uppgift att ringa in områden som påverkades av att leva med smärta (18). I det andra steget värderade 959 individer via en förfrågan på hemsidan för The American Chronic Pain Association, (ACPA) hur de påverkades av dessa områden (18). Insomnings- och sömnsvårigheter med sammanhängande trötthet och upplevelse av svaghet rankades högt liksom smärtans påverkan på nedstämdhet samt sexualliv. Inom det kognitiva området var förekomsten av koncentrations- och minnessvårigheter vanliga. I den sociala dimensionen framträdde svårigheter att ta ansvar för familjen och även andra relationer påverkades negativt. Svårigheter inom yrkes- och hushållsarbete och fritidsliv var också vanliga. Slutsatsen blev att förbättrad funktion och välbefinnande var det viktigaste områdena att ta fasta på $\mathrm{i}$ framtida behandlingsstudier, det vill säga viktigare än smärtan själv (19). Pain Australia (21) är ett nationellt projekt där man på befolkningsnivå dokumenterar och sammanställer erfarenheter av långvarig smärta. Pain Australia bekräftar IMMPACT-gruppens redovisning av viktiga områden i en smärtdrabbads liv som berörs av långvarig smärta.

En stor mängd av andra studier har undersökt aspekter av upplevelsen av att leva med smärta. Här följer några exempel på studier där man använt kvantitativ metod: Rörelserädsla visade sig vanligt i denna grupp (22). Denison et. al visade att betydelsen av individens föreställning om smärtan till exempel rörelserädsla och self-efficacy (tilltro till sin egen förmåga) verkade vara viktigare faktorer för individens funktion än smärtintensitet och hur länge man haft smärta (23). Skillnader i självkänsla jämfördes mellan en grupp med smärta utan kliniska fynd med tre andra grupper, en med reumatiker som hade haft smärta längre än sex månader, en grupp med vuxna utan smärta och en grupp studenter utan smärta. Studien visade att de som hade smärta utan kliniska fynd hade lägre självkänsla än de tre övriga grupperna, men den visade också att deras självkänsla ökade med hjälp av en psykologisk intervention (24). Keefe et al. beskrev i en reviewartikel att smärtrelaterad oro, katastrofierande, rädsla och hjälplöshet är associerade till ökad smärta och sämre sätt att hantera smärta. 
Psykologiska faktorer som däremot hjälper individen är acceptans, bra förmåga till hantering, self-efficacy och förändringsförmåga (25). Sullivan et al. (26) bekräftar att katastroftankar har negativ inverkan på smärta och funktionsnedsättning. När Börsbo et al. (27) studerade samspelet mellan selfefficacy och smärta, depression, katastroftankar, ångest och funktionsnedsättning, livskvalitet och hälsa bland individer med långvarig smärta fann man ett komplext samspel. Self-efficacy var en skyddande faktor mot smärtupplevelse och hade en positiv inverkan på livskvalitet, hälsa och funktion. Motsatt inverkan hade depression, ångest och katastroftankar.

Bland de kvalitativa studierna fann Gustavsson et al. (28) att individer med långvarig smärta eller fibromyalgisyndrom (FMS) upplevde skam och dålig tilltro till sig själva, men att det gick att vända till självrespekt genom rehabilitering. Walker et al fann i sin kvalitativa studie främst förlust i form av socioekonomisk förlust som ledde till förändrade relationer, negativ självvärdering och brist på framtidshopp (29). Steihaug et al. beskrev betydelsen av att bli respekterad och få vara den man är (30).

Sim \& Madden (31) utförde en genomgång av studier rörande den subjektiva upplevelsen av att leva med FMS. En tolkande metod användes för de sammanlagt 23 kvalitativa studierna. Resultaten summerades under de fyra kategorierna "Upplevelsen av sina symptom", "Sökande efter diagnos", "Legitimitet" och "Coping" (31, s.59-63). Gemensamt för fynden i de genomgångna studierna var erfarenheten att FMS som diagnos var tvetydig och osynlig och att den väckte frågor om trovärdighet och legitimitet. Tvetydigheten visades bland annat $\mathrm{i}$ att upplevelsen av smärtan var svår att beskriva som en enda kvalitet. Smärtan beskrevs både som att den kom från ett begränsat område och att den var generellt diffus, både konstant och varierande, både oroande och icke-oroande beroende på hur den påverkade individens funktion.

I en meta-etnografisk systematisk genomgång av 77 framsållade kvalitativa studier rörande patienters upplevelse av långvarig smärta skapade Toye et al. (32) en konceptuell modell. Den beskriver vad de genomgångna studierna betonar som viktigt för att möjliggöra att patienterna ska "Röra sig framåt tillsammans med smärtan": "Integrering av den smärtande kroppen", "Berätta för människor om smärta", "Inse att det inte finns någon bot", "Bli expert", "Vara en del av samhället" samt "Omdefiniera normalitet" (32, s. 834).

Många smärtdrabbade upplever svårighet att bli trodda, trots att man själv erfar sig så begränsad i livet (32-34). När Clark \& Iphofen (34) intervjuade patienter om deras erfarenheter av att smärtan var osynlig, fick de redogörelser för hur 
andra ansåg att smärtan satt i huvudet, att den var psykiskt betingad. Detta väckte ett behov att bevisa att de hade ont, men det kunde också leda till isolering och depressivitet. Patienter beskrev också att de inte kände sig trovärdiga i kontakten med läkaren eller annan sjukvårdspersonal, vilket bekräftas även i andra studier $(34,35)$. Sådana resultat gör det lätt att inse att patienter med långvarig smärta kan uppleva det som värdefullt att få en diagnos som uttrycker att man inte hittar på sina symtom (36-38). Diagnosen kan på så vis legitimera smärtan, men hävdar Malterud och Undeland (39), den kanske inte egentligen är en hjälp för patienten. Frågan om att inte bli trodd handlar mer om vikten att bli respekterad, mött och lyssnad på. Utmaningen är att stödja patientens rehabilitering genom att patienten får hjälp att skapa förståelse bortom diagnosen (39), bland annat genom att bli respektfullt bemött och lyssnad till.

\section{Fysioterapi vid långvarig smärta}

\section{Behandlingen som den ser ut idag}

Till den svenska primärvårdens fysioterapeuter kommer många individer som haft smärta en längre tid. Fysioterapi är ofta förstabehandlingen efter medicinering. Statens Beredning för medicinsk Utvärdering (SBU) har på uppdrag av Sveriges regering och riksdag utvärderat behandling för individer med långvarig smärta $(5,14)$. Därefter har en expertgrupp sammanställt hur behandling bör bedrivas, "Indikationer för långvarig smärta" (8). Expertgruppen förordar att undersökning och behandling ska utgå från en biopsykosocial grund, vilket innebär att fysioterapeuten tar anamnes, undersöker och gör en screening av vilka psykosociala faktorer som kan ha betydelse för att smärtan uppkommer och sedan består. Efter undersökningen och bedömningen görs en behandlingsplan. Primärvårdsfysioterapeuter använder olika smärtlindrande behandlingar. De kan bestå av akupunktur, avspänning, hållningskorrigering/medvetandegörande, ergonomi, funktionsträning i form av styrke- och konditionsträning i träningslokal eller i rehabiliteringsbassäng. Fysioterapeutiska behandlingsformer förankrade i ett helhetsperspektiv på människan finns numer på de flesta håll inom primärvården, och den som dominerar är Basal kroppskännedom. Många fysioterapeuter har i sin grundutbildning introducerats i Basal 
kroppskännedom och ett stort antal har också gått de särskilda kurser som vidareutbildning. Gruppverksamhet som bygger på undervisning och samtal om långvarig smärta, stresshantering och ergonomi är vanligt förekommande.

Vid rehabilitering av långvarig smärta förordar SBU 2010 (14) behandling som sammanför fysioterapi, fysisk aktivitet och träning enligt beteendemedicinska principer som utgår från att beteenden och faktorer i livsstilen kan påverka kroppssymptom och sjukdomars uppkomst och framför allt deras utveckling (40). För en fysioterapeut innebär detta att tillsammans med patienten ur ett biopsykosocialt perspektiv analysera vilka beteenden som ökar eller förhindrar besvären som patienten sökt hjälp för. Till exempel kan tankar, känslor och vanor utgöra hinder för en sannolikt välgörande ökning av den fysiska aktiviteten i vardagen (41).

Smärtlindring är som nämnts ofta inte möjlig men däremot finns en hel del att göra för att funktionen och livskvaliteten ska bli bättre. Rehabiliteringen syftar till att ge patienten olika verktyg att hantera konsekvenserna av smärtan och utveckla sina egna sociala resurser (8). SBU 2006 (5) beskriver att individer med långvarig smärta vill behålla sin värdighet, söker lindring främst i form av självkontroll och har behov av nyorientering och att få samtala om sin smärta. Mål som avser kroppsfunktioner blir delmål och så kallade stödstrategier (8).

På senare år har multimodal teambehandling inom primärvården byggts ut. Patienter med långvarig smärta erbjuds att delta i behandling av team bestående av läkare, arbetsterapeut, psykolog, fysioterapeut och sjuksköterska. De senaste fyra åren har denna form av behandling varit $\mathrm{i}$ fokus för vidareutbildning och samarbete mellan professioner för att hitta former där patienten görs delaktig och får möjlighet att planera sin egen rehabilitering.

\section{Helhetsinriktad fysioterapi}

Som beskrivits ovan arbetar fysioterapeuter med många olika metoder. Inom nordisk fysioterapi har olika former av bedömning och behandling inom psykosomatiska och psykiatriska tillstånd utvecklats, främst företrädda av den svenska metoden Basal Kroppskännedom (Basic Body Awareness, B-BAT) (42) och den norska metoden Psykomotorisk fysioterapi (Norwegian psychomotor physiotherapy, NPMP) (23). Bägge utgår från att se människan som en helhet 
(43). Inom Basal kroppskännedom, förstås kroppen som identitetsbärare och syftar till att integrera kroppen i helhetsupplevelsen av självet och att återupprätta kroppsmedvetenhet och kroppskontroll $(42,43)$. Psykomotorisk fysioterapi bygger på psykodynamisk teorigrund (44) och på förståelsen av kroppen som ett integrerat fysiskt, psykiskt, och socialt fenomen (45). För närmare beskrivning av forskning inom området se Teoretisk ram.

\section{Implikationer för avhandlingsarbetet}

Som beskrivits ovan är långvarig smärta allmänt förekommande och patienter med detta problem utgör ett omfattande arbetsfält inom fysioterapi. Smärtan berör ofta individens hela existens.

Inom fysioterapeutiskt arbete kommer vi ofta nära patienterna både fysiskt och psykiskt, men detta tydliggörs inte alltid och kunskapen om det som sker utöver det kroppsinriktade i biologisk mening är inte så stor. Det kan bli en diskrepans mellan det snäva perspektiv som metoderna har och den existentiella dimensionen i det som sker i behandlingsrummet. Det har visat sig att fysioterapeuter liksom andra inom hälso- och sjukvården kan erkänna att den biopsykosociala modellen bör vara vägledande i arbetet men många har svårt att vidga sitt perspektiv i handling (46-48). För en fysioterapeut som vill möta sin patient $i$ helheten av möjliga och sammanflätade orsaker till och betydelser av långvarig smärta är det oumbärligt att kunna uppfatta upplevelsens valörer, innebörder och sammanhang. Detta måste också kunna reflekteras över tillsammans med patienten. För vi vet inte var smärtans utlösande och vidmakthållande omständigheter ytterst finns. Här krävs ett förändrat förhållningssätt bland dem som arbetar i första linjens sjukvård för att förstå smärtans betydelse i patientens liv och att tillsammans med patienten hitta vägar för att mobilisera patientens resurser och motverka sjukliggörande.

Med bakgrund i de svårigheter fysioterapeuter kan ha att förstå hur individer med smärta upplever sin kropp och sitt problem växte planer fram på att angripa problemet vetenskapligt. Det har visat sig svårt att inom fysioterapin vidga perspektivet för tolkning och behandling, trots att den biopsykosociala modellen funnits sedan slutet av sjuttiotalet och de flesta fysioterapeuter inser att patientens liv och smärta hänger ihop. Metoderna har inte utvecklats i takt med kunskapen och fysioterapeuterna i sjukvårdens bas, med andra ord primärvården, som träffar patienterna tidigt i förloppet, står inte tillräckligt rustade. 
Utgångspunkten för mitt avhandlingsprojekt var just detta: Att ge fysioterapeuter en hjälp att kommunicera med patienten med långvarig smärta på hennes eller hans villkor, och samtidigt göra detta på ett målmedvetet och teoretiskt förankrat sätt. 


\section{SYFTE}

\section{Övergripande syfte}

Syftet har varit att med utgångspunkt i ett kroppsligt existentiellt perspektiv utforska och begreppsliggöra upplevelsen av att leva med långvarig benign muskuloskeletal smärta samt att utifrån detta utveckla en metod för samtal och bedömning inom icke specialiserad fysioterapi.

\section{Delsyften}

\section{Arbete I}

Att ur ett kroppsligt existentiellt perspektiv beskriva hur individer med långvarig smärta förhåller sig till sin värkande kropp.

\section{Arbete /I}

Att undersöka hur fysioterapeuter uppfattade betydelsen av hur ett antal systematiskt förberedda nyckelfrågor om att leva med en kropp som värker, påverkade deras relation till och förståelse av patienter med långvarig smärta.

\section{Arbete III}

Att undersöka vad patienter med långvarig smärta svarade på nyckelfrågor rörande biografi, identitet och "levd kropp", i samtal med behandlande fysioterapeut. Ett andra syfte var att pröva relevansen av fyra begrepp aspekter av kroppsupplevelse - som vi hade med oss från det första arbetet genom att använda dem i ett empiriskt material från ett kliniskt sammanhang.

\section{Arbete IV}

Att undersöka om det var möjligt att förbättra förståelse och kommunikation mellan fysioterapeuter och patienter med långvarig smärta med hjälp av en 
metod som kombinerar nyckelfrågorna om att leva med en kropps om värker med en preliminär referensram för tolkning av svaren - typologier av förhållningssätt till smärta. För att få en uppfattning om nyttan av metoden i primärvården, ville vi också beräkna fördelningen av positiva och negativa erfarenheter som fysioterapeuterna angav när de använt metoden. 


\section{TEORETISK RAM}

\section{Ett förhållningssätt för fysioterapeuter i första linjen}

De rapporter från $\operatorname{SBU}(5,14)$ som nämnts ovan har beskrivit att behandling och rehabilitering vid långvarig smärta framförallt ska riktas mot att reducera smärtans negativa konsekvenser för livskvalitet och livssituation $(5,14,49)$. Dessa forskningsresultat ställer nya krav på både patienterna vars förväntningar och önskningar ofta är att bli av med smärtan, och på hälso- och sjukvården, det vill säga här fysioterapeuterna, som av tradition betraktat smärta utifrån biomedicinsk utgångspunkt $(5,14,49-51)$.

Engels ursprungliga beskrivning av den biopsykosociala modellen (10) tog avstånd från enkla kausala förhållanden och poängterade att all sjukdom får konsekvenser i alla delar av livet. I mötet med patienter är det lätt att tänka kausalitet även om man säger sig företräda den biopsykosociala modellen (47, 52) eller är påverkad av äldre psykosomatiska teorierna (53). Inom smärtbehandling har det visat sig att behandlingar ofta haft begränsad effektivitet mot just smärtan (8). En annan begränsning är att de är teoretiska modeller för helhet, där expertperspektiv läggs till varandra aldrig fångar den verkliga och i egentlig mening hela människan, som kommer till fysioterapeuten med sin smärta (54). Upplevelsen underordnas ett symptomtänkande och hur patienten innerst inne har det och tänker om sin situation kommer ofta inte fram. Denna problematik har under de senaste cirka tjugo åren uppmärksammats, diskuterats och utvecklats vetenskapligt av fysioterapeuter med förankring framför allt $i$ helhetsinriktade traditioner och psykiatrisk fysioterapi (50, 55-64). Gemensamt för dessa forskare är också att de anlägger ett existentiellt perspektiv på kroppen, ibland inom en fenomenologisk referensram. Det biografiska perspektivet har också visat sig värdefullt i studiet av individer med långvarig smärta. Innan jag går in på de aktuella fysioterapeuternas arbeten blir det därför nödvändigt att kortfattat redogöra för dessa utgångspunkter. 


\section{Kroppen ur ett fenomenologiskt perspektiv}

Fenomenologin undersöker levd erfarenhet. Dess grundare Edmund Husserl gjorde en klar distinktion mellan den levda kroppen - das Leib - och kroppen som natur - der Körper (65). Den franske filosofen och fenomenologen Maurice Merleau-Ponty (66) fördjupade fenomenologin om kroppen. Med sitt begrepp "den levda kroppen" (le corps propre) gör han upp med den dualistiska traditionens dikotoma synsätt på kropp och själ. Merleau-Ponty ser kroppen som människans centrum och som bärare av hennes erfarenhet, både i nuet och i det förflutna och som levd är kroppen riktad och öppen mot världen. Det är genom den levda kroppen som en person uppfattar och agerar i den fysiska och sociala världen, den utgör jaget på samma gång som den är en fysisk realitet. All förståelse av oss själva eller av företeelser och förhållanden i världen är grundad i kroppen. Det är genom den levda kroppen vi kommunicerar.

Upplevelsen av kroppen är primärt upplevelsen av mig själv.

När begreppet "kroppsligt existentiellt" i fortsättningen används i avhandlingen är det den "levda kroppen" som åsyftas. I existentiell mening är människan genom kroppen också utlämnad åt det biologiska och ändliga. Kroppen bär livet men också sårbarheten och det för alla människor gemensamma budskapet att livet kommer att ta slut.

Rudebeck beskriver kroppen som levd erfarenhet i hälsa och sjukdom (67). Strukturen i upplevelsen av "kroppen som jag" benämner Rudebeck "den existentiella anatomin". Den innefattar dels kroppen som en vanligtvis tystlåten bakgrund av normalitet, dels fysiskheten som den framträder i den egna erfarenheten från ansträngning och smärta till lätthet och behag och dels hur kroppens olika delar och funktioner får sin betydelse genom den betydelse de har i människans liv. Med handen griper man in i världen och sänder tecken, benen är att stå och kunna förflytta sig och hjärtat slår för livet. Det är genom att gripa in i den existentiella anatomin som sjukdomar och symptom får sina innebörder för den som drabbats. Kunskaper om organ och fysiologi är abstraktioner i förhållande till upplevelsen av den egna kroppen, Gretland beskriver i samma anda hur kroppen kommunicerar mening: "vi känner igen ett leende som något annat än att visa tänderna" (68, s.21). När vi är vid hälsa fungerar kroppen i tysthet, vi tar den för givet i våra liv, men när vi drabbas av sjukdom kommer kroppen i fokus. Det som i sjukvården kallas symptom är egentligen kommunikativa handlingar (67), där patienten försöker beskriva sin upplevelse. Som utsagor är de unika för person och situation, men de har samtidigt de allmängiltiga drag som kroppsligheten fysiskt och existentiellt 
dikterar. Vid långvarig smärta går kroppen över från "jag kan" till "jag kan inte" eller "jag kan inte längre" (69).

För fysioterapeuten innebär "den existentiella anatomin", att i mötet med patienten som presenterar sitt symtom inse just den existentiella dimensionen av det kroppsliga symtomet. När knäet värker så kan kanske patienten inte längre helt lita på sitt ben. Benet med smärta bär inte längre. Hur förändrar det livets villkor? Att lyssna till patientens subjektiva beskrivning av symtomet och vad det innebär blir då utgångspunkt för den fortsatta bedömningen och behandlingen av patientens symtom.

Fenomenologin kan genom sin utforskande beskrivning av den "levda kroppen" eller den "existentiella anatomin" öka vår förståelse av vad sjukdom innebär för den enskilda människan. Patientens subjektiva upplevelse, helheten av förnimmelser, tankar, känslor och föreställningar, det som man på engelska benämner - "illness" - är det primära och alltid giltiga, oberoende av om det går att identifiera avvikelser i den fysiska kroppen eller ej.

\section{Det biografiska perspektivet}

Medicinsk sociologi studerar i gränsområden för folkhälsa, socialt arbete, demografi och gerontologi. De undersöker fenomen i skärningspunkten mellan de sociala och kliniska vetenskaperna. Inom medicinsk sociologi har man bl.a. fokuserat på sjukdomsbegreppet (70). Bury (71) menar att långvarig sjukdom medför ett biografiskt brott - livet skrivs om - och beskriver vad som händer när en individ drabbas av kronisk sjukdom.

Att drabbas av långvarig smärta får konsekvenser i den "levda kroppen" och därmed i individens hela liv $(5,49,50)$. Det fysiska obehaget leder till att individen inte längre känner igen sin kropp. Frågor väcks hur hon eller han ska kunna agera i och handskas med sin sociala och fysiska omgivning (9-14). Värken kommer att styra uppmärksamheten och därmed också existensen (50). Tilliten till kroppen är rubbad och kontakten med den blir förändrad (50, 72). När den blir långvarig orsakar smärtan ett brott i individens biografi vilket också innebär ett hot mot den egna identiteten och självupplevelsen (71, 73, 74). Relationerna till närstående påverkas. Viktiga forskningsområden inom den medicinska sociologin i relation till detta avhandlingsprojekt är anpassningen till att leva med smärta $(73,74)$. Begreppet "biografiska störningar", fångar vad som ofta händer för en person som har en kronisk sjukdom (71). Förmågor och 
aktiviteter som har tagits för givna måste omprövas. För att möta framtiden, behöver den drabbade inse vad som har gått förlorat, vad som finns kvar och vilka utmaningarna kan vara, och sedan, om möjligt, mobilisera de resurser som krävs för att göra en förändring möjlig (71). För att rekonstruera sin biografi, måste individerna omdefiniera sin identitet $(74,75)$.

Gullacksen och Lidbeck (74) beskrev i sin studie tre skeenden som en individ går igenom när hon drabbats av långvarig smärta. I det första skeendet är blicken fäst vid hur livet var tidigare, då hälsa fortfarande kunde tas för given, men sedan gradvis försvinner. I det andra skeendet är nuets svårigheter påtagliga samtidigt som hoten inför framtiden börjar skönjas. En omorientering är nödvändig som i sin tur kräver stor uppmärksamhet och ansträngning. I det skeendet riktas uppmärksamheten direkt mot framtiden men nu med nya förutsättningar.

En avgörande faktor i det biografiska arbetet är frågan om individen kan acceptera det faktum att smärtan kan komma att bestå. Inom gestaltterapi talar man om vikten av acceptans för att bli den man är och hur en s.k. paradoxal förändring då sker (76). Utan denna acceptans kan uppmärksamheten inte riktas mot icke-smärtande aspekter av livet, en insikt som också är kärnan i Acceptance and Commitment Therapy (ACT) $(77,78)$. Denna centrala roll av accepterandet får också stöd i studier av långvarig sjukdom. Charmaz (73) drar slutsatsen från sina resultat att livet som kroniskt sjuk och med nedsatt funktion måste innehålla ett stort mått av accepterande innan en återförening av kroppen och jaget är möjlig. I sin studie av långvarig sjukdom utvecklade, Corbin och Strauss (75) en på empirin grundad teori (grounded theory) om "biografisk kroppsuppfattning" där kroppen utför jagets handlingar i biografisk tid, vilken är kontinuumet av individens förflutna, nuvarande och framtid. Kroppen och den biografiska tiden interagerar ständigt med individens föreställningar om sig själv. Det kroppen klarar eller inte klarar jämförs kontinuerligt med det som individen har klarat eller inte har klarat tidigare och vad detta får för betydelse i framtiden. Detta sker i stort och smått. Som ett exempel kan upplevelsen av att glaset darrar när jag för det till munnen vara en plötslig och ny erfarenhet. Individen kanske reflekterar över vad detta kan få för konsekvens i framtiden? Kanske ingen betydelse eller så kan det vara ett tecken på allvarlig sjukdom. Vid tecken på sjukdom kanske individen frågar sig "vem är jag då?" Människans identitetsskapande processen är ständigt pågående. 


\section{Fysioterapeutisk forskning som bygger på "den levda kroppen"}

Inom fysioterapi har forskning om "den levda kroppen" försökt fånga meningsinnehållet i både patienternas upplevelser av fysioterapeutisk behandling och betydelsen av deras erfarenheter av att leva med sjukdom och fysisk och psykisk funktionsnedsättning. Studier har även studerat fysioterapeuters upplevelse av sitt kliniska arbete och hur de uppfattat att patienter upplever behandlingen.

De flesta vetenskapliga studierna har utgått från patienters och fysioterapeuters upplevelser av fysioterapi. De båda metoderna basal kroppskännedom (B-BAT) och norsk psykodynamisk fysioterapi (NPMP) har varit i centrum för behandlingsstudierna. Dessutom finns studier av det som händer i kliniken interaktionen och kommunikation mellan fysioterapeut och patient och det handlar här om i huvudsak kvalitativa studier och fallbeskrivningar. Flertalet av studierna undersöker vad det innebär att leva med smärta eller förstå individernas upplevelse av sin kropp. Ett par studier är randomiserade kontrollerade studier som undersökt B-BAT.

Rosberg (61) utgår i sina studier från den levda kroppen. Ett centralt problem vid långvarig smärta och stress är att patienterna förlorat kontakten med sin egen kropp och därmed den levda erfarenheten av världen. Rosberg kallar det en förlorad tillit och hemmastaddhet i sin kropp. I samspelet mellan patient och fysioterapeut förstås den värkande kroppen som existens, som relation och som mening utan uppdelningen kropp/själ, biomedicin/psykoterapi. Härigenom kan patienten återfå tilliten till kroppen och sin tillvaro i världen.

Ur ett kroppsligt existentiellt perspektiv undersökte Bullington (79) hur individer med långvarig muskuloskeletal smärta upplevde smärtan, sitt liv och meningsfullheten i rehabiliteringen. Behandlingen som studerades beskrevs som en process. Förhållandet mellan den smärtande kroppen, jaget och världen beskrevs inledningsvis som kaotiskt och desintegrerat. Behandlingen i form av dans- och musikterapi framskred och patienten började förstå vilken mening smärtan hade i hans/hennes liv. Patienterna kunde se sin smärta utifrån och reflektera över den. Det gav dem möjlighet att omformulera smärtans betydelse i deras liv. De var inte längre smärtan utan kunde relatera till den. Patienterna beskrev då att känslan av ordning växte fram. Den värkande kroppen integrerades i jaget. En viktig ingrediens i behandlingen var att fysioterapeuten såg patienten som individ. Detta fick den smärtdrabbade att själv se trådarna mellan smärtan och livet, vilket blev inledningen på en läkningsprocess (79). 
Bullington framhåller att rehabilitering inte bara bör rikta in sig på den fysiska kroppen utan också på att förstå hur smärta är ett biografiskt brott där identiteten och självkänslan förändras och världen utanför krymper (50).

Inom fysioterapeutisk forskning har rörelserädsla tidigare studerats ur ett biopsykosocialt perspektiv. Det gjorde även Lundberg i sin avhandling (80). I den sista av studierna undersökte hon även upplevelsen av att röra sig med smärta ur ett fenomenologiskt perspektiv (58). Hon fann att "att röra sig med smärta innebar mycket mer än själva den fysiska rörelsen eftersom att röra sig i vardagen är att existera i världen" $(58$, s. 205). Trots att informanterna inte kände till begreppet "den levda kroppen", uttryckte de hur världen framträdde genom sina värkande kroppar. En informant beskrev att hon efter träningen kände att det var lättare att gå, hon var mindre spänd och vet att träningen gör att hon mår bättre, "Den stärker hela mig", uttryckte hon (58, s.204). I en senare studie har Lundberg et al. (66) beskrivit vad det innebar för amputerade patienter att få byta till en beninfäst protes. De beskrev att den förbättrade funktion som protesen gav ledde till bättre självkänsla, individerna tyckte bättre om sig själva och återfick sin identitet från tiden före amputationen (81).

Behandlingsstudier har undersökt hur patienter upplever B-BAT. Metoden Basal kroppskännedom utgår från att kroppen är meningsbärande och identitetsskapande och innehåller enkla kroppsrörelser, strävar efter närvaro i dessa rörelser och reflektion över det som sker. I en randomiserad kontrollerad studie fann forskarna att patienter med psykiatriska besvär förbättrat sin kroppsmedvetenhet, sömn, coping och self-efficacy samt sin attityd till sin kropp, (82). I en annan RCT- studie fann Gyllensten et al. (83) att B-BAT gav förbättrad kroppsmedvetenhet och self-efficacy samt färre kroppsliga symtom bland patienter med psykiatriska besvär och somatiska symtom. I en kvalitativ studie fann Gyllensten et al. att B-BAT ledde till (84) förändrad kroppshållning och balans bland en grupp unga schizofrena. Vid multiprofessionell rehabilitering vid långvarig smärta, där B-BAT ingick fann Gustafsson i sin studie indikationer på ökad hälsorelaterad livskvalitet, jämfört med patienter i kontrollgrupperna som fick traditionell fysioterapi. Individerna visade betydande förbättringar rörande kvaliteter såsom grundning, flöde och rörelse förankrad i centrum av kroppen var betydande, och dessa resultat kvarstod efter ett år.

I en studie av kvinnor med smärt- och spänningsproblematik undersökte man effekten av en kombinerad behandlingsserie med kroppskännedomsträning och psykoterapi i grupp (85). Studien visade att kvinnorna förbättrades genom en ökad kroppstillit, ökad förmåga att uppleva och identifiera känslor som i sin tur lett till en starkare jagkänsla. Förutom minskad smärtupplevelse minskade 
även kvinnornas ångest och depressionsupplevelse.

Mattsson (86) fann i sina studier inom fysioterapeutisk psykiatrisk öppenvård där B-BAT använts som en del av behandlingen att patienterna i studierna upplevde en symtomförbättring och stärkt självbild.

En kvalitativ fokusgruppsstudie (87) studerade erfarenheter som gjorts av patienter med olika psykiatriska besvär när de deltagit i Basal kroppskännedomsträning i grupp (B-BAT). Alla deltagarna beskrev innan studiens början, förutom psykiska besvär, även muskelvärk, spänningar och/eller brist på kontakt med sin egen kropp. I analysen utvecklade Johnsen Wikene och Råheim (87) tre grundläggande teman: Deltagarna upplevde dels ökad kroppsmedvetenhet och bättre kunskap om sig själv, dels fick de insikt om att förändring tar tid och sitt eget motstånd mot att delta i arbetet och som tredje tema uttrycktes att B-BAT-gruppen stimulerade deltagarnas utveckling av sin relation mellan sig själv och andra. Liknande processer har beskrivits i studier där psykomotorisk fysioterapi (NPMP) använts som behandling av patienter med långvarig smärta $(56,60)$. Man har i studier undersökt patienters integrering av kroppen i sin identitet. I behandlingen har den levda kroppen varit i centrum och i studierna har visat på att patienterna upplevde sig som förkroppsligade subjekt (60). Man såg erfarenheter av "att vara avskild från kroppen" (60, s.34) hos patienter med kronisk ryggsmärta och möjligheten att genom förändringsarbete återfå en växande känsla av att både vara en kropp och att ha en kropp.

När Gyllensten et al. (57) undersökte vad patienter och fysioterapeuter menade med begreppet kroppsmedvetenhet fann de att det handlade om "förkroppsligad identitet", (embodied identity), med två underkategorier "leva i kroppen" och "leva med andra och världen"(57, s.442), vilket liknar resultaten i ett flertal kvalitativa studier där man undersökt upplevelser och erfarenheter i samband med B-BAT och NPMP. Gyllensten et al. menar att kroppsmedvetenhet är oskiljaktig från identiteten och att den påverkar individens hälsa. Därför bör fysioterapeutisk behandling alltid integreras med kroppsmedvetenhetsövningar.

\section{Interaktionen i det fysioterapeutiska mötet}

Interaktion mellan fysioterapeut och patient är tillsammans med hälsa och kroppsrörelse grundpelare inom den fysioterapeutiska professionen (88-91). I interaktion ingår kommunikation och relaterande. Tyni-Lenné (92) som 
skapade en modell för fysioterapiprocessen beskriver hur interaktionen aktiverar patientens resurser, bidrar till problemlösning samt underlättar val mellan olika behandlingsalternativ (93).

Inom professionen finns en medvetenhet om att samtalet och samtalskonst har betydelse för utfallet av det kliniska mötet. Att fysioterapeuter frekvent erbjuds och deltar i olika kurser i samtalsmetodik exempelvis Motiverande samtal (MI) och kognitiv beteendeterapi (KBT) för fysioterapeuter) kan ses som ett tecken på interaktionens betydelse. Många fysioterapeuter har också utbildat sig inom olika inriktningar av samtalsterapi.

Kliniskt beslutsfattande "clinical reasoning" är ett område för utvecklandet av hur man som professionell tänker och överväger beslut och löser problem i sitt arbete. I detta arbete har fysioterapeuter även studerat vad som händer i mötet mellan fysioterapeut och patient. Förutom fysioterapeutens självständiga kognitiva process har man även undersökt narrativa tekniker för att få tillgång till patientens sjukdomserfarenhet (94). Det senare kräver både sociala och emotionella förmågor av fysioterapeuten (94). Martin betonade vikten av den egna erfarenheten som bas för interaktionen med patienter, där fysioterapeutens egna svåra erfarenheter kan bidra till en fördjupad förståelse för både sig själv och patienten (95).

Patientcentrering är samlingsbegreppet för olika initiativ och modeller som syftar till att förbättra kommunikationen mellan patienter och professionella inom vården. Utvecklingen har till stor del skett inom allmänmedicin. En av förgrundsgestalterna var den engelske psykiatern Balint $(96,97)$. Han hade främst ett psykodynamiskt perspektiv när han såg på relationen mellan patient och läkare. Metoden byggde på grupphandledning för engelska allmänläkare på 50- och 60-talet, där de undersökte sina egna känslor inför de patienter de upplevde sig ha svårt att hjälpa och vad dessa känslor kunde säga om patientens problem. I mötet med patienten syftade metoden till att läkaren skulle vara delaktig i mötet med hela sin person och använda sina erfarenheter och vara uppmärksam på sina egna känslor. Han/hon skulle också kritiskt reflektera över sitt eget handlande och tänkande. Ytterst syftade allt detta till att läkaren skulle stå öppen inför innebörden av patientens erfarenheter. Balint menade att mötet också var en möjlig inlärningssituation för läkaren. Metoden har spridit sig över världen framförallt i Europa och USA. De flesta vetenskapliga studier som gjorts om Balintgrupper och deras möjliga effekter berör grupper med läkare, men metoden har också vunnit insteg inom andra 
hälsoarbetande professioner (98). I sin avhandling beskriver Holmström att Balintmetoden (99) som innebär att få tid för reflektion, handledning och professionell utveckling, borde införas i hela vårdsystemet för att skapa förutsättningar för en högkvalitativ vård. Metoden har även använts inom professionell handledning för fysioterapeuter som ett verktyg för att förstå fysioterapeut-patientrelationen bättre (89).

Patient - fysioterapeutrelationens betydelse för framgångsrik behandling har poängterats $(100,101)$. Den är ibland ansedd som till och med viktigare än valet av behandlingsmetod (100). Hall et al. undersökte och fann att en god arbetsallians föreföll ha samband med positivt utfall av behandlingen (102). Gyllensten (91) understryker vikten att vara mentalt närvarande i mötet. I en studie av Kidd, Bond \& Bell (103) ansåg patienterna att fysioterapeuternas förmåga att tala med, relatera till och förstå människor var mycket värdefulla egenskaper. Westman, Kumlin och Kroksmark (104) fann att genom att lyssna på patienten, kunde fysioterapeuten få information som var av betydelse för behandling och aktivering av patientens resurser. Studier har visat att både fysioterapeuter $(91,100,104)$ och patienter $(103,105)$ ser vikten av att tillvarata patienternas resurser. Thornquist (106) betonade redan 1990 vikten av att båda parter bidrar i mötet men att fysioterapeuten har det yttersta ansvaret för att patientens upplevelser och erfarenheter kommer till uttryck.

I behandlingsmetoderna Basal Kroppskännedom, B-BAT, (93) och Psykomotorisk fysioterapi, NPMP, där helhetssyn på människan är central ingår inte någon specifik samtalsmetod, men samtalet är integrerat i behandlingen genom reflektion över det som upplevs under övningarna (107). I en narrativ studie som undersökte hur individer med ryggsmärta upplevde NPMP drogs slutsatsen att metoden kunde hjälpa patienterna att utveckla potentiellt läkande berättelser och en förbättrad känsla av sin kropp genom att integrera både fysisk och verbal behandlingsmetod (60). Man menar att den positiva förändringen baserades på den terapeutiska relationen vilken uppmuntrade till reflektion över de kroppsliga erfarenheterna.

Rosberg undersökte och beskrev i sin avhandling år 2000 (61) hur fysioterapeutisk behandling vid långvarig muskuloskeletal smärta och spänningsproblematik kan ses som en social process där patienten får uppleva sig själv i samspel med fysioterapeuten. Behandlingen var helhetsinriktad fysioterapi. Relationen är då en förutsättning för och ett viktigt redskap i behandlingen. Bullington et al. fann på liknande sätt $i$ en studie på en smärtklinik att grunden för att uppnå en god fysioterapeut - patientrelation var ett jämbördigt 'jag-du-möte'. Bullington beskriver också att det är fruktbart att 
inta inställningen att man inte ska förändra den andre det vill säga patienten (55).

Inom fysioterapi har det första mötet mellan patient och fysioterapeut studerats med särskilt intresse eftersom det i mycket bestämmer vad som ska ske under det kommande behandlingsförloppet (106, 108, 109). Ekerholt och Bergland (109) fann att det var vid första mötet inom psykomotorisk fysioterapibehandling som förtroende för fysioterapeuten grundlades, väsentligt var att patienten kände sig sedd och uppfattade att fysioterapeuten var kompetent. Thornquist jämförde fysioterapeuter med tre olika specialiseringar (106). I den studien visar hon hur patienternas erfarenheter ges olika utrymme; den ortopedmedicinske delger sitt beslut, den psykomotoriske sätter ramarna men involverar patienten och fysioterapeuten som arbetar inom äldreomsorgen i patientens hem för en dialog med patienten. Interaktion handlar om två parter, men den relationella aspekten på mötet är ofta negligerat skriver Thornquist i sin studie från 1990. Även Josephson som disputerade i 2013 fann i sina studier att fysioterapeuterna, trots sina goda intentioner, ofta missade möjligheten att ta till vara patientens egen syn på sitt problem och därmed hans/hennes resurser (108).

\section{Sammanfattning av teoretiska utgångspunkter}

Rehabilitering vid långvarig smärta ska som nämndes, enligt SBU 2010 (14), framförallt riktas mot att reducera smärtans negativa konsekvenser för livskvaliteten, vilket ställer nya krav på fysioterapeuter som främst är utbildade inom biomedicinsk tradition. Om patientens upplevelse underordnas ett symptomtänkande, kan patientens egen förståelse av hur han/hon innerst inne har det och tänker över smärtans innebörd missas. För att fånga patientens upplevelse har forskare anlagt ett existentiellt perspektiv på kroppen för utforskande beskrivning av den "levda kroppen" ibland inom en fenomenologisk referensram.

Forskning rörande människans identitetsskapande processer som ständigt pågående och det biografiska perspektivet har visat sig värdefullt när man studerar individer med långvarig smärta och rehabilitering. Vad krävs för att för att individen som drabbats av smärta ska kunna gå vidare i livet med en identitet som inkluderar en värkande kropp? 
Interaktionen och mötets betydelse i fysioterapeutisk praktik har undersökts och befunnits avgörande för framgångsrik behandling. Forskning om detta ligger som en grundpelare för denna avhandling. Interaktionen har ibland ansetts som till och med viktigare än valet av behandlingsmetod. En god arbetsallians förefaller ha samband med positivt utfall av behandlingen. När en sådan allians är upprättad, blir den fysioterapeutiska behandlingen också en medvetandegjord social process där patienten får uppleva sig själv i samspel med fysioterapeuten.

Dessa tre teoretiska fält avspeglas i avhandlingsprojektet; det kroppsligt existentiella, det biografiska och det kliniskt kommunikativa. 


\section{MATERIAL OCH METOD}

\begin{tabular}{|l|l|l|l|l|}
\hline Arbete & Metod & Material & År & Syfte \\
\hline I & $\begin{array}{l}\text { Individuella } \\
\text { intervjuer } \\
\text { Fenomenologi }\end{array}$ & $\begin{array}{l}\text { Transkription av 20 } \\
\text { patientintervjuer }\end{array}$ & 2002 & $\begin{array}{l}\text { Explorativt } \\
\text { Beskriva hur det är att leva } \\
\text { med långvarig smärta }\end{array}$ \\
\hline II & $\begin{array}{l}\text { Gruppintervjuer } \\
\text { Fenomenografi }\end{array}$ & $\begin{array}{l}\text { Transkription av } \\
\text { gruppintervjuer. } 6 \\
\text { fysioterapeuter } \\
\text { (ftp) provade } \\
\text { nyckelfrågor på ca } \\
40 \text { patienter }\end{array}$ & 2004 & $\begin{array}{l}\text { Undersöka hur ftp upplevde } \\
\text { nyckelfrågors inverkade på } \\
\text { deras relation till och } \\
\text { förståelse av patienter med } \\
\text { långvarig smärta }\end{array}$ \\
\hline III & $\begin{array}{l}\text { Kliniska samtal } \\
\text { Deduktiv kvalitativ } \\
\text { innehållsanalys } \\
\text { utifrån kliniskt } \\
\text { funna begrepp }\end{array}$ & $\begin{array}{l}\text { Transkription av } 8 \\
\text { patienters samtal } \\
\text { med 3 ftp vid två } \\
\text { olika tillfällen }\end{array}$ & 2005 & $\begin{array}{l}\text { Undersöka patienters svar på } \\
\text { nyckelfrågorna och ge } \\
\text { empirisk grund åt fyra } \\
\text { tidigare funna begrepp, } \\
\text { aspekter av } \\
\text { kroppsupplevelse }\end{array}$ \\
\hline IV & $\begin{array}{l}\text { Öppna frågor } \\
\text { Innehållsanalys med } \\
\text { kvalitativ och } \\
\text { kvantitativ metod }\end{array}$ & $\begin{array}{l}\text { Transkription av } 31 \\
\text { ftp:s svar på öppna } \\
\text { skriftliga frågor } \\
\text { efter patientmöten } \\
\text { (totalt 90) }\end{array}$ & 2010 & $\begin{array}{l}\text { Undersöka möjligheten att } \\
\text { förbättra förståelsen och } \\
\text { kommunikationen mellan ftp } \\
\text { och patient genom } \\
\text { användande av en klinisk } \\
\text { metod: Nyckelfrågor och } \\
\text { typologier av förhållningssätt } \\
\text { till smärta. Samt att } \\
\text { undersöka dess } \\
\text { användbarhet i primärvård }\end{array}$ \\
\hline
\end{tabular}

Figur 1. Material och metod

\section{Material}

Informanterna i studierna har varit både patienter med långvarig smärta och fysioterapeuter som arbetat med patientgruppen både inom primärvård och på specialistklinik. 


\section{Material arbetet I}

Inklusionskriterierna för patienterna var individer som sökt fysioterapeut för förutom långvarig smärta också hade någon form av spänningsproblematik. Tjugo individer med långvarig smärta intervjuades. Tretton av de intervjuade var kvinnor och sju var män mellan 30 och 72 år gamla med en medianålder på 50,4 . Tio var helt sjukskrivna, de övriga arbetade i olika hög grad förutom två som hade ålderspension. 3 var inte födda i Sverige. De flesta hade eller hade haft fysiskt belastande arbeten.

\section{Material arbete II}

Informanterna var sex fysioterapeuter med lång erfarenhet av att arbeta med patienter med långvarig smärta. De var alla kvinnor, tre arbetade på specialistkliniker inom tre olika landsting, två arbetade inom primärvård och en hade egen fysioterapipraktik. Fysioterapeuterna arbetade alla på skilda arbetsplatser.

\section{Material arbete III}

Inklusionskriterierna för patienterna var långvarig smärta. De skulle förstå och tala svenska. Patienterna hade remitterats till smärtklinik eller själva sökt fysioterapeut i primärvård för sina besvär. Åtta kvinnor mellan 18 och 59 år deltog i studien. Tre arbetade, fyra var i rehabiliteringsprogram, en hade sjukersättning. De arbetade eller hade arbetat inom jordbruk, administration, industri eller vård.

Alla tre fysioterapeuter som deltog hade varit informanter även i arbete II. Alla var kvinnor med lång klinisk erfarenhet. En fysioterapeut arbetade på specialistklinik, en inom primärvård och en i egen fysioterapipraktik. 


\section{Material arbete IV}

I det avslutande arbetet valde vi att noggrannare definiera patientgruppen. Vi riktade oss till ett stort antal fysioterapeuter som inkluderades för att de arbetade inom primärvård och inte på grund av speciell erfarenhet av arbete med patienter med långvarig smärta.

I studien där fysioterapeuter samtalade med patienter preciserades inklusionskriterierna för patienterna genom att den långvariga smärtan skulle finnas i minst två av kroppens fyra kvadranter som ett tecken på generalisering och att smärtan inte skulle vara reproducerbar med fysioterapeutiska undersökningsmetoder. Patienterna måste kunna förstå och tala god svenska. Nittio patienter ingick i studien, de hade alla sökt fysioterapeut inom primärvården för muskuloskeletal smärta. 83 av patienterna var kvinnor och sju var män. Åldern varierade mellan 20 år och 74 år med medianåldern var 50 år.

31 fysioterapeuter varav fem var män deltog. Fyra av männen deltog efter en andra omgång av riktad rekrytering. Fysioterapeuternas ålder var mellan 26 år och 64 år med medianen 41,5. Antal år i yrket varierade mellan 1-37, med en median på elva år inom primärvården.

\section{Metod}

Metoderna har varierat med de olika delarna av projektets syfte och karaktär. Det kroppsligt existentiella perspektivet har funnits som grund för utformningen av studierna.

\section{Metod arbete I}

\section{Kvalitativ forskningsintervju}

Stor vikt lades vid att förbereda själva intervjun och utformningen av en intervjuguide. Målet med intervjun var att engagera patienterna i att beskriva och reflektera över sin situation och sina kroppsupplevelser så konkret och ingående som möjligt. Samtidigt som vi fokuserade på intervjuguiden var vi 
medvetna om att intervjun skulle vara så förutsättningslös som möjligt (110) och intervjuaren skulle vara lyhörd för och medveten om att samtalet försiggick i en mellanmänsklig interaktion. I vårt fall stod ordet "nyfikenhet" skrivet med stora bokstäver på intervjuguiden, detta betydde även att intervjuaren skulle vara uppmärksam på att intervjun inte skulle vara ett terapeutiskt samtal.

Intervjuguiden skulle utgöra en hjälp att fånga fenomenet, en människas upplevelse av sin kropp, sina besvär och smärtans betydelse för det liv han/hon levde genom att konstruera frågeområden och ställa frågor bortom det uppenbara, in i ett kanske oreflekterat område. I arbetet med att utforma intervjuguiden hämtade vi inspiration från olika traditioner.

Medförfattaren och handledaren Carl Edvard Rudebecks arbete kring den existentiella anatomin (67) var tillsammans med Roxendals $(42,111)$ och Nordwalls (111) arbeten rörande Basal kroppskännedom och Basic Awareness Scale vägledande $\mathrm{i}$ formulerandet av de frågor som riktades inåt, mot den upplevda kroppen. För att skapa en relief mot en tidigare upplevelse av den egna kroppen infogades en fråga som riktades mot upplevelsen av kroppen som barn.

Gestaltterapins utgångspunkt (112) att man har svar inom sig på det som är av betydelse prövades med en fråga där individen behöver inta en metaposition $i$ förhållande till sin smärta; Vad skulle smärta säga om den kunde tala? Detta är en metod som också har använts av den norske psykiatern Tom Andersen (113), där han framhåller att frågorna ska vara lagom annorlunda vilket utmanar individen att tänka nytt, men inte så annorlunda att han/hon sluter sig eller tar avstånd.

I slutfasen av arbetet med guiden hämtades inspiration från allmänläkaren och forskaren Kirsti Malterud (114-116). Hon utvecklade i sin avhandling en metod för hur allmänläkare kan ställa frågor till kvinnliga patienter med diffusa besvär så kallade nyckelfrågor, för att "bekräfta kvinnans kompetens med hennes egna ord" sid. 110 (114) och genom dessa frågor tydligt visa att det är patienten själv som besitter kunskap om besvären och dess roll i livet, till exempel: "Vad har du hittills kommit på är det bästa du själv kan göra för dina besvär?", sid. 146 (114).

Frågorna i den slutgiltiga intervjuguiden indelades i grupper, med huvudteman och följdfrågor. Ingångsfrågan var: "Kan du beskriva Dina besvär. Jag tänker på de besvär som fick Dig att uppsöka fysioterapeut". Intervjuguiden uppdelades i teman: Subjektiv förklaringsmodell, besvärens betydelse i livet, relationen till kroppen - inre upplevelsen av kroppen, hur individen lever med smärta. Vi hade dessutom en allmän del (Se bilaga 1). 


\section{Vetenskapsteoretiska och metodologiska utgångspunkter}

Inom fenomenologin undersöks hur mänskligt medvetande skapar mening som en förutsättning för att kunna uppleva och förhålla sig till det som sker. För att besvara forskningsfrågan i arbete I som handlar om att få förståelse för hur det är att leva med en kropp som värker valde vi en fenomenologisk ansats.

\section{Empirical Phenomenological Method, EPP}

Inledningsvis genomlästes de transkriberade intervjuerna flera gånger för att få ett helhetsintryck. Materialet var mycket omfattande ca 600 A4-sidor text, med dubbelt radavstånd. För att göra materialet hanterbart minskades intervjuerna genom att vi tog bort textstycken som inte rörde forskningsfrågan. Därefter grupperades innehållet i huvudområden. Exempel på huvudområden var besvär, behandling, coping, kropp och känslor.

Det förtätade materialet analyserades i enlighet med Empirical Phenomenological Method (EPP) (117):

Steg 1. Återigen lästes materialet för att få så kallad "Empatisk förståelse" (Empathic Understanding, EU), vilket innebär att forskaren avsiktligt försöker undvika att tolka materialet utifrån teorier och i stället utgår från den intervjuades utgångspunkt.

Steg 2. I steg två identifierades meningsbärande enheter (MU) i varje intervju.

Steg 3. Författarna tolkade de meningsbärande enheterna så kallad tolkande förståelse. (Interpretative Understanding, IU). Detta moment upprepades genom att gå fram och tillbaka mellan empatisk förståelse och tolkande förståelsen för att säkerställa att tolkningarna var förankrade i materialet.

Steg 4. En synops skrevs för varje intervju, det vill säga en sammanfattande text av de tolkade MU. Alla synopser jämfördes med ursprungsintervjuerna.

Steg 5. Slutligen jämfördes synopserna i ett omfattande arbete för att kunna beskriva deras gemensamma och allmängiltiga meningsinnehåll. Vi bildade fyra huvudkategorier: Kroppen som en aspekt av identiteten, kroppstillit, kroppsmedvetenhet samt sätt att förstå smärtan. Synopserna kunde därefter en och en analyseras i ljuset av de fyra kategorierna varvid likheter och skillnader framstod tydligt som typologier. De fyra typologierna beskrev informanternas 
förhållningssätt till långvarig smärta och en värkande kropp. Detta innebar att kategorierna rekontextualiserades när deras giltighet prövades mot de ursprungliga individuella berättelserna.

\section{Metod arbete II}

\section{Utveckling av nyckelfrågorna}

Resultatet av intervjustudien där den tidigare beskrivna guiden (Bilaga 1) användes gav oss tanken att flera av frågorna skulle kunna användas i kliniskt arbete av fysioterapeuter i mötet med individer med långvarig smärta.

För att frågorna skulle vara möjliga att använda i kliniks praxis bedömde vi att tidsaspekten var viktig. Vi valde således ut ett antal frågor som vi i arbete I funnit gav särskilt innehållsrika svar om hur det var att leva med smärtan och där patienterna berättade hur de kände och tänkte om sin kropp. Vi redovisar här den slutgiltiga versionen av de sju nyckelfrågorna.

Fråga ett och två handlar om patientens syn på sin smärta och dess konsekvenser i dagliga livet. De har tydlig fokus på att det är patienten som besitter kunskap om sitt tillstånd. Inspirationen från Kirsti Malteruds emancipatoriska frågor är tydlig (114-116).

1. Vad tror du Dina besvär kommer sig av?

2. Hur förändrade Dina besvär Ditt liv? Berätta. Beskriv områden i Ditt liv där besvären har liten betydelse och där de har stor betydelse.

Fråga tre, fyra och dess följdfrågor handlar om förhållningssätt till den värkande kroppen. Inspirationen är Rudebeck (54) och Roxendal (42) men traditionen går tillbaka till fenomenologen Maurice Merleau-Pontys (66) förståelse av "den levda kroppen"

3. Litar Du på Din kropp? Beskriv. Om Du inte litar på Din kropp nu, har Du gjort det någon gång i livet?

4. Upplever Du att Din kropp är med Dig eller mot dig?

Fråga fem ska bilda relief till nuet. Den är tänkt att möjliggöra kontakt med barnkroppen och känslan som finns inför den. Möjligtvis kan den också väcka kroppsminnen.

5. Hur var Din kropp när Du var barn? 
Fråga sex är som nämndes hämtad från Gestaltterapi (76) och ger möjlighet till metaperspektiv på individens upplevelse av sin smärta. Det här kan också likna det sätt som används inom bildterapin eller när fysioterapeuter tittar tillsammans med patienten på dennes smärtteckning.

6. Om smärtan kunde tala, vad skulle den säga?

Fråga sju är biografisk och visar hur patienten tänker om sina val i livet.

7. Med facit i hand, nu när Du mår som Du mår, skulle Du ha handlat annorlunda om Du fick chans att leva om Ditt liv?

Fråga fem användes först $i$ arbete III. Fråga fyra är ett förtydligande av fråga tre, som gjordes till arbete IV.

När patienterna i studien inbjöds att samtala med hjälp av nyckelfrågorna skulle fysioterapeuten vara aktivt närvarande med en öppen, nyfiken inställning i samtalet. Hon eller han skulle försöka att tygla sin professions reflex att själv hitta lösningar på "den andres" problem. I samtalet innebar det att patienten var subjektet och fysioterapeuten var den intresserade lyssnaren. På så sätt skulle ett intersubjektivt fält skapas där den gemensamma förståelsen kunde utvecklas. Innan fysioterapeuterna prövade frågorna i sitt vardagsarbete gick forskaren igenom det här förhållningssättet och syftet med studien.

\section{Fenomenografi}

Fenomenografi är en kvalitativ ansats som från början utvecklades inom pedagogisk forskning (118-120). Med fenomenografisk ansats studerar forskaren människors uppfattningar om företeelser och förhållanden som de erfar. Likt fenomenologisk filosofi utgår fenomenografin från erfarenheten men den problematiserar inte erfarenheten som sådan utan tar världens framträdelseformer - fenomenen - för givna. Inom fenomenografin studerar man alltså hur världen uppfattas vilket kallas "ett andra ordningens perspektiv" vilket ställs i kontrast till fenomenologins "första ordningens perspektiv". Uppfattningar är långt ifrån alltid reflekterade utan utgörs också av sådant som tas för givet och som hjälper till att ge överblick och sammanhang åt vardagserfarenheten. När sådana "förgivettaganden" inom olika praktiker och sammanhang beskrivs och begreppsfästs blir det lättare att förstå hur uttalade uppfattningar, och i förlängningen handlingar, formas. Ett 
grundantagande inom fenomenografin är att ett fenomen kan uppfattas på kvalitativt olika sätt men att det samtidigt handlar om ett begränsat antal sätt. Ambitionen är att tydligt urskilja och beskriva dessa olikheter. När man betraktar ett fenomen från ett speciellt perspektiv visar sig mönster som inte framträder ur andra perspektiv. Hur fenomenet uppfattas varierar med kontexten. Kontexten utgör i strukturell mening den yttre horisonten. Samtidigt är det i relation till kontexten fenomenet framträder som "något" över huvud taget vilket är den omedelbara och referentiella aspekten av fenomenet. Mot den inre horisonten - $\mathrm{i}$ fenomenologin, varifrån horisontbegreppet kommer, är horisonter medvetandets beredskap att ge mening åt erfarenheten - framträder fenomenets sammansättning eller struktur (121). I sin betoning av hur ett fenomen framträder på olika sätt beroende på sammanhang eller bakgrund delar fenomenografin vissa gemensamma ståndpunkter med gestaltpsykologins teori. På samma sätt som fenomenets helhet eller gestalt varierar med kontexten varierar också strukturen. I ett perspektiv blir vissa aspekter av särskild betydelse, medan de i ett annat utgör bakgrund. När en ond axel undersöks i ett biomekaniskt perspektiv blir varje vävnadsstruktur viktig. När samma smärta ses som en del i en sammansatt smärtproblematik förskjuts uppmärksamheten mer mot smärtans innebörder och konsekvenser medan lokala smärtmekanismer mer kommer i bakgrunden. Det finns med andra ord ingen absolut distinktion mellan struktur och referens, eftersom inte heller strukturen kan frikopplas från meningssammanhanget (122). De referentiella aspekterna är ofta underförstådda eller tagna för givna i det en informant berättar i intervjun och ett led i analysen är därför att frilägga de olika perspektiv informanten anlägger på fenomenet. Om en patient har träffat sin distriktsläkare kan patienten till exempel relatera resultatet till en lyckad behandling eller till att hon eller han fătt en bättre förståelse av sitt problem (123). Inte förrän sammanhanget blir klart blir det också klart vad som läggs in i fenomenet "resultat" (124). Referenserna är implicita i detaljerna av patientens erfarenheter och tankar. Helheten av de referentiella och strukturella aspekterna inom ett perspektiv bildar det man kallar en beskrivningskategori. Tillsammans ger beskrivningskategorierna det studerade fenomenet dess utfallsrum, som därmed representerar de olika uppfattningarna om, eller variationen av, fenomenet.

När det gäller förhållandevis distinkta fenomen, som hur läkarstudenter uppfattar vetenskapliga fenomen (89) eller allmänläkare vad astmabehandling går ut på (125), blir inte bara de olika uppfattningarna men också relationerna dem emellan tydliga. Element kan vara gemensamma men få olika innebörder beroende på vilka perspektiv de aktuella beskrivningskategorierna 
representerar. Utfallsrummet är då inte bara de olika beskrivningskategorierna utan också en logisk och empiriskt förankrad struktur som kan bli väsentlig förkunskap när man till exempel planerar en utbildning. Det är emellertid inte alltid möjligt att skapa en sådan tydlig struktur för varje utfallsrum. När fenomenografi används i studier av vidare erfarenhetsfält som hur det är att leva med implanterad defibrillator (126) eller vad som underlättar eller försvårar livsstilsförändringar vid koronarsjukdom (127) eller vad som blir resultat av besök hos allmänläkare (123) blir undersökningarna mer öppet explorativa och det blir svårare att tydliggöra relationerna mellan de olika beskrivningskategorierna och därmed att ange en sammanhängande struktur för hela utfallsrummet. I dessa studier har heller inte en sådan struktur någon framträdande plats i resultatredovisningen. I den explorativa situationen blir fördelen med fenomenografin framför allt dess inriktning på att inordna uppfattningarna i tydligt olika perspektiv. Arbete II är explorativt.

\section{Fokusgruppsintervjuer}

I studie två ville vi utveckla och pröva nyckelfrågor för användning vid kliniska samtal med individer med långvarig smärta. Sex erfarna fysioterapeuter tillfrågades och deltog genom att under två månader använda nyckelfrågorna $\mathrm{i}$ sitt kliniska arbete. Därefter samlades de i en fokusgruppintervju. Efter att under denna diskuterat sig fram till mindre förändringar i frågornas ordning och följdfrågor fortsatte fysioterapeuterna att använda frågorna i kliniken under ytterligare två månader och därefter träffades fokusgruppen åter. Materialet $\mathrm{i}$ arbete II var dessa två fokusgruppsintervjuer. Intervjuerna inleddes med frågan; "Hur var det för dig att använda nyckelfrågorna i ditt arbete med patienter med långvarig smärta?" Fysioterapeuterna uppmanades att samtala med varandra och inte med forskningsledaren som också ledde fokusgruppssamtalet. Samtalen flöt vid bägge tillfällena livligt i ca två timmar. Samtalen spelades in på ljudband. På detta sätt fick forskarna tillgång till fysioterapeuternas professionella reflektion. Fokusgrupper är betraktade som en lämplig intervjuform då grupprocessen hjälper till att få fram material (128, 129). Fokusgrupper är däremot inte vanligt inom fenomenografi och kan ses som ett avsteg från metoden. I utskrifterna är dock de individuella svaren klart urskiljbara och utskrivna med fysioterapeutens namn. Sammanlagt provade fysioterapeuterna frågorna på ca 40 patienter. 


\section{Analys}

Analysen utfördes i huvudsak i enlighet med sju stegen av fenomenografisk analys såsom beskrivits av Sjöström och Dahlgren (130), förtrogenhet, sammanställning, kondensering, gruppering och klassificering, jämförelse och revidering, namngivning och beskrivning av kategorier och slutligen kontrasterande jämförelse. Gruppintervjuerna som bandats transkriberades med stor noggrannhet och med särskiljande av de enskilda deltagarna. Materialet lästes igenom och banden lyssnades på tills materialet var väl känt (förtrogenhet).

Uppmärksamheten riktades mot hur fysioterapeuterna, i kontrast mot deras tidigare erfarenheter av behandling av långvarig smärta, uppfattade innebörden och konsekvenserna av att använda nyckelfrågorna. De svar som var av intresse för forskningsfrågan lyftes ur den ursprungliga texten och sammanställdes. De enskilda utsagorna kondenserades till enstaka ord eller korta uttryck som sammanfattade utsagornas innebörd. Redan i denna fas framträdde några teman. Till exempel kommenterade flera fysioterapeuter patienternas livserfarenhet och att frågorna lett till starka känslor hos patienterna. En preliminär gruppering av utsagor började därför tidigt och denna gruppering blev mer klar och fast när hela det kondenserade materialet hade delats upp tematiskt och det därmed blev möjligt att jämföra likheter och skillnader. Konsistensen av varje grupp prövades mot de övriga, och utsagor av mer tvetydigt innehåll flyttades mellan grupperna tills dessa fick status av definitiva kategorier. Dessa kategorier kunde sedan hänföras till tre olika perspektiv som genom kontrasterande jämförelse i analysens allra sista steg fastställdes som beskrivningskategorier och därmed utfallsrummet. De kategorier som byggde upp beskrivningskategorierna blev samtidigt underkategorier i - eller aspekter av -respektive beskrivningskategori. Under analysens olika steg gick vi tillbaka till det ursprungliga materialet som helhet för att säkerställa att de teman som utvecklades, och senare kategorierna, var förankrade i det icke kondenserade ursprungsmaterialet. Enligt Bowden (131) har uttalanden två sammanhang, det ursprungliga materialet och det kondenserade, där det senare inte längre är bundet till specifika individer. Den bakgrund mot vilken resultatet framträdde var fysioterapeuternas tidigare erfarenhet av samtal med individer med långvarig smärta (132). Med andra ord gav utfallsrummet en samlad meningsstruktur åt ett stort antal specifika händelser i mötet mellan fysioterapeuterna och deras patienter. Fysioterapeuterna uppfattade dessa händelser ha samband med att de använde nyckelfrågorna. 


\section{Metod arbete III}

\section{Deduktiv kvalitativ analys}

En deduktiv kvalitativ metod användes. En sådan är tillämplig om syftet är att testa tidigare funna teorier, modeller eller begrepp i ett nytt sammanhang, i en annan patientgrupp eller över tid (133-135). Den deduktiva analysen baseras på tidigare funna resultat och kan beskrivas som att den går från det generella till det specifika och därifrån med nyanseringar eller nya innebörder hos begreppen. Gränsen mellan deduktiv och induktiv analys är inte skarp, båda har inslag av varandra. Skillnaden ligger i analysens huvudsakliga rörelse; från begrepp till enskildhet eller från enskilda intervjuutsagor till övergripande kategorier eller begrepp.

I det deduktiva arbetet kan man bestämma om man endast väljer de delar i materialet som begreppen/matrisen fångar eller välja att analysera hela materialet, det vill säga även delar som bör angripas induktivt.

Syftet med studien styr valet av metod (134). I arbete III var matrisen för den deduktiva analysen de fyra begrepp för kroppsupplevelse som vi utvecklat $\mathrm{i}$ arbete I.

\section{Arbetets Design}

De åtta patienterna svarade på nyckelfrågorna vid det första och det avslutande samtalet under behandlingsserien. Samtalen spelades in på ljudband. Tiden mellan samtalen varierade från två till sju månader. Den mellanliggande behandlingen var inte $\mathrm{i}$ fokus för vår studie, men eftersom den ingår i det sammanhang i vilket frågorna ställdes presenterar vi den mycket översiktligt $i$ artikeln. Behandlingen skiftade mellan patienterna; tre hade deltagit i Feldenkraispedagogisk behandling, tre ingick i en multimodal smärthanteringsgrupp på specialistklinik och två patienter fick individuellt upplagd behandling inom primärvården t.ex. fysisk träning, avspänningsträning, akupunktur och kroppskännedom.

\section{Analys}

I vår deduktiva kvalitativa analys (133-135) användes de fyra begreppen från arbete I, vilka beskrev fyra aspekter av kroppsupplevelse. Begreppen fick 
tillsammans funktionen av en matris i den deduktiva analysen (135). Resultatet från arbete I som gett de fyra aspekterna av kroppserfarenhet innehöll också beskrivningar av dessa (figur 2).

Kroppstillit innebär olika grad av tillit till och förmåga att samarbeta med sin kropp samt klara smärtans oförutsägbarhet. En individ kan både ha och i olika hög grad sakna kroppstillit.

Kroppsmedvetenhet innebär kvaliteten av det perceptuella flödet från kroppen

Sätt att förstå sin smärta är individens egen beskrivning av varför han/hon fick och fortfarande har smärtproblematik.

Kroppen som en aspekt av identiteten - mer eller mindre integrerad

Figur 2. Begrepp som bildade matris för den deduktiva analysen

På detta sätt prövades begreppen här i ett nytt sammanhang, det vill säga i en klinisk verksamhet med en behandlande fysioterapeut som genomförde samtalet utifrån de sju nyckelfrågorna. Data var de ljudbandinspelade fysioterapeut- patientsamtalen. Banden transkriberades och materialet genomlästes så att det blev väl känt och gav en helhetsbild.

Meningsbärande enheter (MU) identifierades och kondenserades till en mer koncentrerad form. I nästa steg läste vi MU mot matrisen med de fyra begreppen, aspekterna av kroppsupplevelse, och sorterade de kondenserade MU till respektive begrepp. I studien ville vi främst studera begreppens innehåll och gränser i det nya sammanhanget. För att få en fördjupad kunskap om dem försökte vi hålla oss öppna för nya aspekter av begreppen i hela datamaterialet. Vi återgick till de transkriberade intervjuerna om och om igen. Med alla MU för varje begrepp och deras motsvarigheter i de kompletta utskrifterna fick vi ett brett underlag. Vi kunde rekontextualisera begreppen i detta nya empiriska sammanhang och få en tydligare uppfattning om begreppens räckvidd och gränser. Begreppens innebörder utvecklades samtidigt som vi genom dem kunde beskriva hur patienterna svarade på nyckelfrågorna. En sammanfattande text om varje begrepp skrevs, vilken utgör resultatdelen. Dessutom jämfördes texterna från första och andra samtalet för att se på likheter och skillnader i patienternas svar. Dessa är också redovisade i resultatdelen. (se figur 3). 


\begin{tabular}{|c|c|c|c|}
\hline Begrepp & $\begin{array}{l}\text { Identifiering av } \\
\text { meningsbärande enheter (MU) }\end{array}$ & $\begin{array}{l}\text { Kondensering } \\
\text { av MU }\end{array}$ & $\begin{array}{l}\text { Delar av den } \\
\text { kontextuella } \\
\text { innebörden av } \\
\text { begreppet }\end{array}$ \\
\hline \multirow{4}{*}{ Kroppsmedvetenhet } & $\begin{array}{l}\text { Gerd samtal I } \\
\text { Det var bara så att man ska gå till } \\
\text { jobbet ... även om jag var dålig så } \\
\text { svalde jag några extra tabletter ... } \\
\text { som gjorde det lättare ... } \\
\text {... jag lyder inte, så att säga ... det } \\
\text { har jag aldrig gjort... } \\
\text { Gerd samtal II } \\
\text { Nej, nu känner jag att det finns en } \\
\text { gräns, och nu måste jag inse det, } \\
\text { jag börjar förstå. Men det är en } \\
\text { lång väg att gå, jag har mycket att } \\
\text { lära fortfarande. }\end{array}$ & $\begin{array}{l}\text { Lyssnar inte på } \\
\text { kroppen } \\
\\
\text { Långsamt } \\
\text { börjar } \\
\text { kroppens } \\
\text { signaler att } \\
\text { kännas igen }\end{array}$ & $\begin{array}{l}\text { Kroppen är ett } \\
\text { hinder som } \\
\text { måste avvisas }\end{array}$ \\
\hline & $\begin{array}{l}\text { Anne samtal I } \\
\ldots \text { Nu har jag gjort för mycket, då } \\
\text { är det som om kroppen säger att } \\
\text { nu måste du ta det lugnt ett tag ... } \\
\text { Anne samtal II } \\
\text {... kroppen är också tydlig med } \\
\text { vad den inte vill och det blir } \\
\text { jättetydligt när jag lyssnar på den }\end{array}$ & $\begin{array}{l}\text { Kroppen säger; } \\
\text { ta det lugnt } \\
\text { Kroppen har } \\
\text { en tydlig röst- } \\
\text { om man } \\
\text { lyssnar }\end{array}$ & $\begin{array}{l}\text { Beaktar hur } \\
\text { mycket } \\
\text { kroppen tål } \\
\text { Medvetenhet } \\
\text { om kroppens } \\
\text { signaler } \\
\text { Förändring }\end{array}$ \\
\hline & $\begin{array}{l}\text { Åsa samtal I } \\
\text { Men det lyssnade jag inte på } \\
\text { eftersom det inte var något fel på } \\
\text { mig, (sa läkarna till mig) } \\
\text { Åsa samtal II } \\
\text { Nu vet jag hur jag kan läsa } \\
\text { kroppen och nu vet jag vad den } \\
\text { påverkas av }\end{array}$ & $\begin{array}{l}\text { Lyssnar inte } \\
\text { det är ju inget } \\
\text { fel på kroppen }\end{array}$ & $\begin{array}{l}\text { Kan inte } \\
\text { urskilja viktiga } \\
\text { signaler }\end{array}$ \\
\hline & $\begin{array}{l}\text { Gun samtal II } \\
\ldots \text { Man är mer uppmärksam, på } \\
\text { sig själv vad man ska göra, vad } \\
\text { man ska lyfta, vad man kan göra } \\
\text { och hur det kommer att fungera }\end{array}$ & $\begin{array}{l}\text { Smärtan får } \\
\text { dig att lyssna } \\
\text { och anpassa } \\
\text { ditt handlande }\end{array}$ & $\begin{array}{l}\text { Identifierar } \\
\text { signalerna }\end{array}$ \\
\hline
\end{tabular}

Figur 3. Deduktiv analys med exempel från begreppet kroppsmedvetenhet 


\section{Metod arbete IV}

I detta avslutande arbete ville vi undersöka vilka erfarenheter ett större antal fysioterapeuter i ordinarie primärvård gjorde när de använde nyckelfrågorna och sedan i direkt anslutning bedömde vilket förhållningssätt patienterna hade till smärtan. Vid bedömningen uppmanades de att använda typologierna från arbete I som en möjlig referensram. Vi ville också veta hur fysioterapeuterna uppfattade nyttan och användbarheten av detta arbetssätt. Samtidigt ville vi få en indikation på arbetssättets potential för en bredare användning. Därför valde vi en metod som byggde på kvalitativ analys av fysioterapeuternas erfarenheter och uppfattningar som samtidigt gav möjlighet att kvantifiera positiva och negativa uppfattningar.

\section{Kvalitativ metod med kvantifiering av koder}

Den kvalitativa analysen utformades för att förstå och strukturera de 31 fysioterapeuternas erfarenheter. Den kvantitativa delen utformades för att analysera i vilken utsträckning de olika erfarenheter och uppfattningar förekom.

Den kvalitativa innehållsanalysen genomfördes med en något modifierad metod beskriven av Hickey \& Kipping (136). Metoden är speciellt utformad för en rigoröst systematisk analys av ett stort material av skriftliga svar på öppna frågor. Centralt i metoden är att forskarna stegvis och individuellt analyserar materialet och mellan stegen jämför sina analysresultat. Detta leder till en successiv syntes av kodningarna. Till metoden hör också att forskarna tidigt $\mathrm{i}$ processen utvecklar huvudkategorier i vilka detaljkoder sedan fördelas.

\section{Analys}

Data var fysioterapeuternas skriftliga svar på åtta öppna frågor som de besvarade direkt efter sitt möte med patienten (figur 4). Sammanlagt blev det svar från 90 patientmöten. 
1. Beskriv vad som hände när du ställde nyckelfrågorna till den här patienten?

2. Beskriv hur du upplevde att det var för den här patienten att besvara frågorna?

3. Hur påverkades din bedömning av patientens besvär av att du använde typologierna A-D?

4. Hur påverkade det som du fick fram genom nyckelfrågorna och typologierna ditt förslag till behandling?

5. Finns det någon annan typ av behandling som du efter samtalet med patienten tänker vore önskvärd?

6. Hur tror du frågorna inverkade på patientens egen reflektion över att leva med värk?

7. Hur påverkade frågorna din relation till patienten?

8. Om du vill berätta något ytterligare har du möjligheten att göra det här.

Figur 4. Frågor till fysioterapeuterna som deltog i arbete IV.

I innehållsanalysen identifierades meningsbärande enheter (MU) i en tredjedel av de enskilda svaren på de öppna frågorna. Dessa MU kondenserades och tilldelades koder. Därefter jämförde och diskuterade vi analysresultatet Maria Afrell (MA) kodade därefter hela materialet. Separat utvecklade forskarna preliminära kategorier i samma tredjedel av materialet. Åter jämförde vi resultaten och jämkade tills vi var överens. I hela materialet fördelade MA detaljkoderna till huvudkategorierna och grupperade dem i underkategorier. Dessa kontrollerades av Carl Edvard Rudebeck (CER). I fördelningen av koderna, ifrågasatte vi placeringen av enskilda koder under hela processen och ibland flyttade vi dem. Materialet var relativt enkelt och lätt att koda och kategorisera. Ett antal svar som bedömdes ha mindre intresse med avseende på forskningsfrågan uteslöts ur kodningen. I det sista steget, och med ett visst tidsavstånd från det huvudsakliga analysarbetet, återvände vi till koder och deras motsvarande svar. Koderna och deras fördelning, blev då i vissa fall justerade och likaså behövde namn på underkategorier också jämkas och justeras. I själva verket blev detta arbete inte avslutat förrän manuskriptet var klart. 


\section{Dikotomisering och kvantifiering av kvalitativa data}

Resultatet av den kvalitativa analysen innehöll tre huvudkategorier och ett antal underkategorier. Huvudkategorierna fick en enkel sorterande funktion som följde de öppna frågorna som fysioterapeuterna besvarade. Den mer differentierade kunskapen om materialet finns i underkategorierna.

För att kunna beräkna i hur hög grad de olika kategorierna förekom i fysioterapeuternas svar räknade vi antalet MU i varje kod, dock endast en för varje samtal. Vi skapade då ett system för vilka svarskoder som kan bedömas som positiva respektive negativa. Materialet dikotomiserades (figur 5). I de samtal där fysioterapeuten inte angett ett svar som gick att hänföra till en kod användes en nollkod. Denna överföring från ett kvalitativt resultat till ett kvantifierbart kallas inom mixed methods design för "Quantitizing the data" (137).

\begin{tabular}{|l|c|c|}
\hline $\begin{array}{l}\text { Kategori B: Upplevd användbarhet och nytta av nyckelfrågor } \\
\text { och typologier }\end{array}$ & $\begin{array}{c}\text { Positiva } \\
\text { subkategorier }\end{array}$ & $\begin{array}{c}\text { Negativa/neutrala } \\
\text { subkategorier }\end{array}$ \\
\hline $\begin{array}{l}\text { B1. Förståelsen för patienten } \\
\text { 1. Ökar, 2. Ökar inte }\end{array}$ & 1 & 2 \\
\hline $\begin{array}{l}\text { B2. Användbarhet vid bedömning och behandling: } \\
\text { 1. Generell positive betydelse, 2. Hjälper vid val av specifik } \\
\text { behandling, 3. Användbarhet vid bedömning och val av } \\
\text { behandling, 4. Påverkar inte bedömning och behandling }\end{array}$ & $1-3$ & \\
\hline $\begin{array}{l}\text { B3. Speciellt bidrag av typologierna: } \\
\text { Ger 1. helhetsbild, 2. accepterandeprocess, 3. förhållningssätt till } \\
\text { smärta }\end{array}$ & & \\
$\begin{array}{l}\text { Föreslår 4. ett nytt perspektiv } \\
\text { Fysioterapeuten 5.ser behandlingsbehov, 6. ger professionell } \\
\text { säkerhet, 7. får hjälp med bedömningen eller } \\
\text { 8. Typologierna ger ingen hjälp, 9. Ingen typologi passar }\end{array}$ & \\
\hline
\end{tabular}

Figur 5. Exempel på hur dikotomiseringen skapades i kategori B mellan positiv versus neutral/negativ erfarenheter

\section{Statistisk analys av dikotomiserad data}

De trettien fysioterapeuterna, varav en betraktades som två individer med olika ID-nummer (vilket efter beräkning av materialets homogenitet visade sig inte störa resultatet), gav $\mathrm{n}=32$. Varje underkategori och varje fysioterapeut 
beräknades där positiva svar respektive neutrala/negativa svar erhållits (varierar med antal patienter per fysioterapeut). Eftersom materialet var Poisson-fördelat, kunde logaritmer av data analyseras med hjälp av ett parat ttest (analyserades separat för varje underkategori) med ln (antal) som beroende variabel där ln var den naturliga logaritmen. För att undvika problemet med att räkna med noll, har $\ln$ (värdet plus 0,5 ) använts. En signifikansnivå på $\mathrm{p}<0,05$ användes. Data analyserades med Statistica version 10 (Statistica; StatSoft ${ }^{\circledR}$, Tulsa, OK, USA). 


\section{ETIK}

Den etiska diskussionen som följt studierna har handlat om när och hur nyckelfrågorna ställs. Eftersom frågorna ibland har väckt starka känslor hos patienterna har vi betonat vikten av att fysioterapeuten själv måste ha tillräcklig tid för och intresse av att höra det patienten berättar. Hon/han behöver inte kunna hjälpa patienten med allt som beskrivs, men att bekräfta en människas berättelse hör till en allmänmänsklig del av vårdpersonals uppgift. Ingenting under studiernas gång har visat på att patienterna tagit skada av att besvara nyckelfrågorna.

Arbete: I, III och IV är godkända av etikprövningsnämnden i Linköping. Inför studie II tillfrågades etisk expertis i etikprövningsnämnden i Linköping. Deras bedömning var att ett formellt etiskt godkännande inte var nödvändigt eftersom fokus i studien var fysioterapeuternas erfarenhet utan direkt inblandning av patienterna. 


\section{RESULTAT}

Studierna utgår från ett kroppsligt existentiellt perspektiv. Tillsammans pekar resultaten på en möjlig metod för fysioterapeuter att ha som en grund för fysioterapi vid långvarig smärta. Metoden går ut på att fysioterapeuten först ställer de sju nyckelfrågorna i behandlingssamtalet, och sedan prövar de fyra typologierna, en referensram för tolkning av förhållningssätt till smärta, i sin bedömning av det patienten berättar och det som kommer fram i undersökningen. Arbete I och III utgår från patientperspektivet och arbete II och IV från fysioterapeutperspektivet.

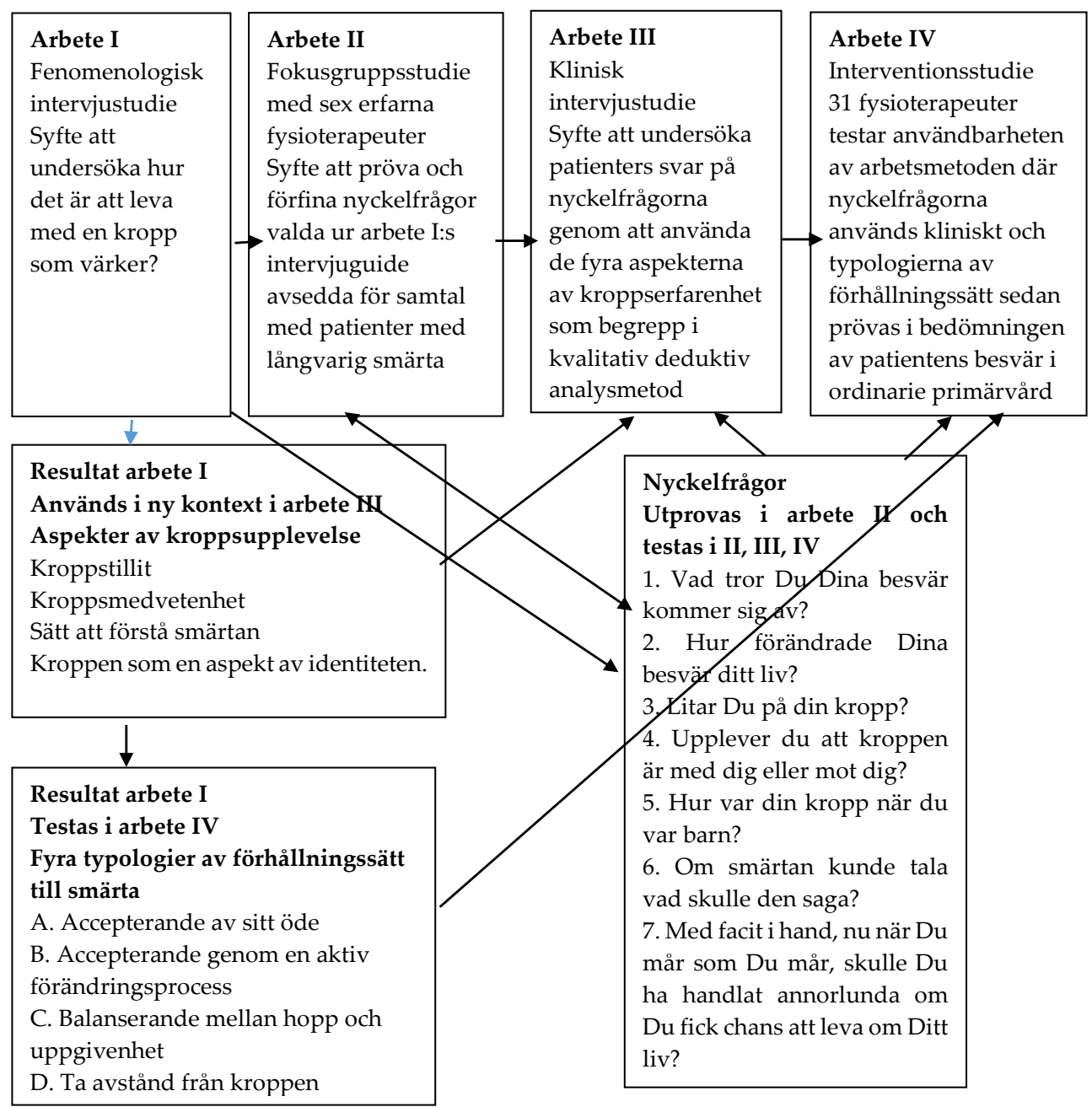

Figur 6. Hur arbete II - IV är utvecklade ur arbete Iss resultat och intervjuguide 


\section{Resultat arbete I och III Att leva med en kropp som värker och att utifrån nyckelfrågor samtala om den värkande kroppen}

I det första arbetet analyserades patienters svar i intervjun om hur det är att leva med en kropp som värker, där den tidigare nämnda intervjuguiden användes. I resultatet frilade vi fyra aspekter av kroppsupplevelse; kroppstillit, kroppsmedvetenhet, smärtförståelsen och kroppen som en aspekt av identiteten. De fyra aspekterna av kroppsupplevelse var olika framträdande hos olika individer men fyra samlande typologier av förhållningssätt till smärtan kunde urskiljas.

I arbete III är det patienternas svar på nyckelfrågorna, ställda av den behandlande fysioterapeuten vid två behandlingstillfällen i början och i slutet av behandlingsförloppet, som analyserats. I denna studie användes aspekterna av kroppsupplevelse som begrepp i en deduktiv analys.

Det var möjligt att hitta utsagor i samtalen som motsvarade alla de fyra aspekterna av kroppsupplevelse. Påtagliga skillnader framträdde mellan patienterna och ibland också mellan de två samtalen för samma patient och då på ett sätt som föreföll spegla en positiv utveckling. I svaren kunde patienternas biografiska avbrott och möjliga restauration i livsberättelsen skönjas.

\section{Fyra begrepp - aspekter av kroppsupplevelse}

Redogörelsen för begreppen utgår från arbete I och de fylls därefter ut av de nya innebörder som tillkommit i arbete III.

Kroppstillit är något som patienterna i det första arbetet hade i olika hög grad eller inte alls. För några individer var det möjligt att lita på sin kropp trots värk, man beskrev att man litade på kroppen även i dess oberäknelighet. Kroppen var som den var, men att nå fram till en sådan tillit kunde ha inneburit ett avsevärt arbete. För några var det möjligt att uppleva kroppen som en resurs även i smärta. Andra beskrev en tydlig ambivalens, där värken exempelvis ena dagen kunde framkalla känslor av rädsla och oro och en den andra dagen tacksamhet när kroppen gav vägledning i hur livets påfrestningar kunde hanteras. För några av patienterna var kroppen så gott som uteslutande en fiende. 
Dessa innebörder av begreppet kroppstillit tog vi med oss i arbete III där vi instruerade fysioterapeuter att ställa nyckelfrågorna i behandlingssamtalet med patienter. Vi fann att begreppet "kroppstillit" var rikt representerat i patienternas svar och därmed blev vår önskan att få större empiriskt underlag för "kroppstillit" infriad. De flesta tycktes utan att tveka kunna svara på om de litade på kroppen eller inte. De beskrev också hur smärtan utmanade deras tillit till kroppen, men trots detta fann vi återigen att det fanns en möjlighet att känna kroppstillit trots smärtan och kroppens oförutsägbarhet. Som barn hade de flesta haft kroppar de kunnat lita på. Flera tecknade en självbild där de hade varit en pojkflicka som klättrade i träd och spelat fotboll med grabbarna, men erfarenheter fanns även av att tilliten kunde bli förstörd av barndomens mobbning och föräldrarnas skilsmässa.

Vid det andra samtalet, som ägde rum när behandlingen avslutades, fanns uttryck för en ökad tillit till kroppen.

Kroppsmedvetenhet innebär förmåga att identifiera och bedöma sinnesintryck, vegetativa reaktioner och känslornas kroppsliga innehåll och möjliggör förmågan till anpassning. Patienterna beskrev att smärtan hade satt kroppen i förgrunden. De hade olika upplevelser av sin kontakt med kroppen. För några var det helt naturligt att lyssna på kroppens signaler och de anpassade sig till sin minskade kapacitet i det dagliga livet. De hade lärt sig att inte längre kämpa mot smärtan genom att exempelvis bli frustrerade eller ilskna på den. På så vis, beskrev de, hade både kroppskännedom och självkännedom förbättrats. Genom att lyssna på kroppen och lära av den hittade individen ett nytt förhållande till sin kropp. Hos andra fanns en påtaglig tvetydighet. Kontakten fanns ibland och ibland inte. Tolkningar av kroppens signaler gick isär. Individen rörde sig mellan att lyssna på kroppen och att stänga av den. För andra var det inte möjligt att lyssna på kroppens signaler. Deras enda möjlighet var att ta avstånd från kroppen.

Till begreppet "kroppsmedvetenhet" i arbete III hörde beskrivningar av den balansakt som patienterna med smärta utförde för att klara av livets krav.

För vissa var det möjligt endast under korta perioder att lyssna på kroppen, medan det för andra aldrig verkade bli möjligt. Några ignorerade signalerna och pressade sig, medan andra såg smärtan som viktig information som ledde till en viss anpassning. Att ignorera kroppen verkade vara en copingstrategi som gjorde det möjligt att undvika förändringar som i viktiga avseenden ifrågasatte identiteten. Med tilltagande smärta blev förändring till sist oundviklig. 
Patienter beskrev att deras kroppsmedvetenhet förändrats mellan samtalen. De hade blivit bättre på att "läsa" sina kroppar.

Smärtförståelsen var olika bland patienterna. För några var deras smärta orsakad av vävnadsskada till följd av trauma eller ihållande belastning. Andra beskrev att man inte tagit hänsyn till hur kropp och själ var sammanlänkade. Man beskrev att man inte hade lyssnat på sin kropps signaler. För andra var orsaken till smärtan komplex, men att individen försummat varningssignaler från kroppen nämndes ofta. För en liten grupp av patienterna var smärtan helt obegriplig och orättvis.

I arbete III byttes "förståelse" ut mot "förklaring" eftersom svaren främst innehöll tankar om kausalitet. Även flera av dessa patienter menade att smärtan berodde på att de struntat i att ta hand om sig själv och skjutit undan kroppens varningssignaler. Andra var mer fatalistiska och verkade se smärtan som mer eller mindre tillhörande livet. Några beskrev samband mellan smärtan och livet i en vidare mening och där det ingick även psykologiska påfrestningar i förklaringarna till att det gjorde ont.

I det andra samtalet uttryckte ytterligare några patienter ett samband mellan sitt liv och sin smärta där även deras eget handlade fanns bland orsakerna.

Kroppen som en aspekt av identiteten. Patienterna beskrev att de, för att kunna integrera sin värkande kropp i sin identitet, måste anpassa sig till de förutsättningar kroppen gav. Om man klarade det var man i harmoni men för den skull inte fri från smärtor. Några beskrev integreringen av kroppen som ett förtroendefullt och hoppfull samarbete mellan jaget och kroppen. De som hade ett ambivalent förhållande till sin kropp kunde ibland inse att acceptans var den enda vägen framåt, men förtvivlan tog ofta över. I sådana stunder eller perioder sågs kroppen främst som förändrad och svår att uthärda. För de patienter $\mathrm{i}$ studien som helt tog avstånd från kroppen fanns ett svagt hopp om att någon doktor, någon ny medicin eller någon annan behandling $\mathrm{i}$ framtiden skulle kunna hjälpa dem.

Formuleringen från arbete I "Kroppen som en aspekt av identitet" ändrades i arbete III till "Integrering av den värkande kroppen i identiteten" för att tydligare binda begreppet till sammanhanget smärta. I arbete III bekräftades begreppets innebörd och innehåll. Individerna befann sig i spannet mellan att ha accepterat sin situation med en kropp som värker och att aldrig kunna tänka sig att göra detta. För några blev den ur den egna erfarenheten framväxande insikten att kropp och själ var en enhet en väg mot integrering. Likaså kunde 
självrespekt och självtillit vara betydelsefulla för att integrera den värkande kroppen i sitt jag. Avståndstagande från den egna kroppen, eller ambivalens, motverkade den adaptiva processen. I mötet med vården hade några fått beskedet att det inte var något fel på dem, vilket gjorde situationen obegriplig och integrationen av den värkande kroppen svårare.

I analysen av det andra samtalet fanns bland patienterna svar som antydde en förändring i riktning mot en ökad integrering av den värkande kroppen. En patient beskrev hur hon nu när hon förstod att smärtan inte skulle försvinna hade återupptagit aktiviteter på ett nytt sätt. En annan beskrev att identiteten hade förändrats, hon hade kommit närmare sina vänner och satte sina gränser bättre. För andra var integrering fortfarande en omöjlig tanke.

\section{Typologierna - referensram för tolkning av förhållningssätt.}

Som beskrivits tidigare fanns en stor variation inom de olika aspekterna av kroppsupplevelse. I arbete I fann vi att variationerna hade en logik och vi kunde beskriva fyra typologier av förhållningssätt till den långvariga värken:

A. Att acceptera sitt öde var ett lugnt läge. Individerna lyssnade till sin kropp och inrättade livet efter vad kroppen klarade. Man förmådde också känna tillit till kroppen trots dess oberäknelighet. Den värkande kroppen var en del av identiteten.

B. Att acceptera genom en aktiv förändringsprocess var vägen för några. För att behålla sin självrespekt ser man på det som skett på ett realistiskt sätt och anpassar sig aktivt och medvetet. Man ser att förändringen kan vara positiv. Man hade tidigare inte lyssnat på sin kropp men genom smärtan kom kroppen nu i fokus och då insåg man att om man inte bekämpade kroppen så kunde tilliten och kroppsmedvetenheten öka. Man såg sig som en helhet av kropp och själ. Detta fick till följd att man lyssnade till kroppen även i smärta och genom detta fick vägledning. Att inte ha lyssnat till kroppen sågs som en orsak till att man drabbats av smärta. Integrering av kroppen i identiteten krävde ett tillitsfullt samspel.

C. Att balansera mellan hopp och uppgivenhet innebar att ibland klara att känna tillit till och lyssna till sin kropps signaler och att ibland köra på utan att orka ta hänsyn till dem. Hos samma person kunde smärtan ömsom ge rädsla och oro och ömsom tacksamhet för att den hjälpte till att balansera livets belastningar. 
Förklaringarna till smärtan såg olika ut i denna typologi; skada, förslitning eller överbelastning, stress eller sårbarhet eller att inte lyssnat på kroppens signaler, varav den sista ofta var i kombination med någon av de andra. Patienterna visste att vägen till att må bättre var att acceptera kroppen, men att det ofta inte var möjligt.

D. Att ta avstånd från kroppen innebar att över huvud taget inte känna tillit och att inte lyssna till sin kropps signaler. Man saknade kontroll och inget hjälpte mot smärtan. En integrering av den smärtande kroppen var inte möjlig. Smärtan var obegriplig och orättvis. Förklaringen var skada eller förslitning, men där ingick även reflektion över hur man hanterat sin kropp.

Det biografiska perspektivet och typologierna. I arbete III blev det biografiska perspektivet tydligt när resultatet studerades i sin helhet. Livets gång framträdde i svaren på nyckelfrågorna och i brottet av patienternas biografi eller livsberättelse. Svaren demonstrerade också patienternas kamp för att reparera brottet och integrera den förändrade kroppen i sin identitet. En dåtid, där patienterna mindes sin egen kropp som barn tillsammans med tankar om kroppen före smärtan, bildade bakgrund. Mot denna beskrev patienterna hur de nu hanterade sin besvärliga och ibland oförutsägbara kropp. Tankar på framtiden involverade inte bara oro eller bekymmer utan ibland även hopp och förtröstan.

Även om typologierna, referensramen för tolkning av förhållningssätt till smärta, inte var $\mathrm{i}$ fokus $\mathrm{i}$ arbete III så kunde man se dem avspeglade $\mathrm{i}$ patienternas svar på nyckelfrågorna.

\section{Resultat arbete II: "Vi fick hela historien på en gång"; fysioterapeuters användning av nyckelfrågor i mötet med patienter med långvarig smärta}

"We got the whole story all at once; physiotherapists' use of key questions when meeting patients with long-standing pain"

De sex fysioterapeuterna som medverkade i studien prövade nyckelfrågorna $\mathrm{i}$ sitt kliniska arbete. Svaren blev innehållsrika och fysioterapeuterna uppfattade att frågorna påverkade patienterna och genom patienternas gensvar även dem 
själva. Tre beskrivningskategorier, som motsvarar olika perspektiv på vad frågorna uppfattades tillföra, utgjorde tillsammans utfallsrummet:

"Fysioterapeuternas insikter om patienten som person", "En förändring inom patienten" samt "En förändring av fysioterapeutens relation till patienten"

\section{Fysioterapeuternas insikter om patienten som person}

Att smärtan är nära till känslor

Att patienten har ord

Att smärtan speglar livserfarenhet

Att patientens uppfattning om sambandet mellan kroppen och livet kommer fram

Fysioterapeuterna beskrev hur de överrumplats av att så mycket starka känslor var inblandade i att leva med smärta. Det var också tydligt att patienterna kunde svara på de, som åtminstone en av fysioterapeuterna uppfattade dem, svåra och symboliska frågorna. När patienterna berättade med hjälp av nyckelfrågorna framträdde också hur avgörande skeenden och förhållanden i deras liv sett ut och vad som föreföll ha bidragit till och påverkat smärtan. Fysioterapeuterna beskrev också att frågorna hjälpte dem att inse hur patienterna själva såg på förhållandet mellan värken och det liv man levt.

\section{En förändring inom patienten}

Att nyckelfrågorna startade en process inom patienten.

I svaren på nyckelfrågorna uttryckte patienterna sina tankar och känslor om sin värk. Patienterna fick möjlighet att verbalisera och ta ställning till sina strategier för att klara av livet med smärta. På detta sätt inledde nyckelfrågorna en process som blev en självklar del av behandlingen som hjälpte till att gå vidare i rehabiliteringen. Detta kunde vara avgörande för vilken behandling man skulle erbjuda eller för bedömningen att behandling över huvud taget var möjlig.

\section{Förändring av fysioterapeutens relation till patienten}

Att möta det svåra

Att ompröva sitt professionella mandat 
Fysioterapeuterna beskrev att det kan vara krävande att inom sitt yrkesuppdrag "stå ut med", det vill säga härbärgera, patienternas smärtfyllda historier och starka känslor. Trots vetskap om att de inte kunde undvika dessa problem, önskade fysioterapeuterna ibland att de kunde hjälpa patienten att vända hans/hennes negativa attityd och koncentrera sig på det som kan vara positivt $\mathrm{i}$ stället. De saknade nyckelfrågor som riktades mot möjligheter i livet. Att möta den ena smärtdrabbade individen efter den andra kunde ge terapeuten en känsla av maktlöshet och irritation.

Gränserna för det professionella mandatet blev ifrågasatta och framstod som delvis oklara. Fysioterapeuterna insåg att det patienterna hade upplevt i livet starkt påverkade både deras smärta och deras förmåga att leva med den. Men hur djupt i "ryggsäcken" som en fysioterapeut hade rätt att gräva återkom hela tiden i gruppdiskussionerna och man var generellt försiktig. En av fysioterapeuterna kände dock att det blivit enklare med åren och numera tyckte hon inte att det var svårt att fråga hur livet påverkade smärtan. I gruppen som helhet förelåg en klar ambivalens mellan å ena sidan den dominerande biomedicinska synen på fysioterapeutyrket och å andra sidan erfarenhet från kliniken där det stod klart att hela livet påverkade smärtan. Fysioterapeuterna nämnde olika teorier och forskning som stöder användningen av ett biopsykosocialt perspektiv, men trots detta fanns fortfarande en viss tveksamhet.

\section{Resultat arbete IV: Att förbättra samspelet mellan fysioterapeuten och patienten med långvarig smärta}

"Improving the interaction between the physiotherapist and the patient with long-lasting pain"

I sina svar på de öppna skriftliga frågorna beskrev fysioterapeuterna följande: Att i de samtal som nyckelfrågorna banade väg för kände sig patienterna ofta bekräftade. De kunde berätta hur det var för dem att leva med smärta. Fysioterapeuterna blev å sin sida delaktiga och fick därmed möjlighet att nå en djupare förståelse för patienterna. Dessutom kunde fysioterapeuterna uppleva att relationen till patienterna förbättrades. 
Genom typologierna av förhållningssätt till smärtan kunde fysioterapeuten få en uppfattning om var i rehabiliteringsprocessen patienten befann sig och/eller få en bekräftelse på sin egen bedömning och ställningstagande till behov av behandling.

Resultatet visade också att nyckelfrågorna inte var till nytta i alla patientmöten och detsamma gäller för typologierna.

\section{Resultatets kvalitativa del}

Resultatet av den kvalitativa innehållsanalysen sorterades enligt tre deskriptiva huvudkategorier:

Patienternas gensvar på nyckelfrågorna

Användbarheten och nyttan av nyckelfrågorna och typologierna Betydelsen av nyckelfrågorna för relationen mellan patient och fysioterapeut

Innehållet i resultatet framträder i underkategorierna.

\section{Patienternas gensvar på nyckelfrågorna}

Underkategorier: Omedelbar reaktion, emotionell reaktion, reflektion samt upplevelse av förändring under samtalet.

Fysioterapeuterna uppfattade att nyckelfrågorna var enkla och intressanta att besvara för de flesta av patienterna. Frågorna fick också patienterna att börja eller fortsätta reflektera och hos några satte en mer tydlig process igång. Beskrivningar fanns av att frågorna väckte känslor av sorg och ilska men även av glädje och nyfikenhet.

\section{Användbarhet och nytta av nyckelfrågorna och typologierna}

Underkategorier: Förståelse, nyttan för bedömning och behandling samt typologiernas speciella bidrag.

Fysioterapeuterna angav att nyckelfrågor och typologier gav en bättre förståelse för patientens problematik, dock inte i alla fall. I de patientmöten där 
fysioterapeuter angav att nyckelfrågor och typologier underlättade, upplevdes nyttan främst inom områdena bekräftande av tidigare bedömning och att hitta rätt nivå och struktur på behandlingen. Detta gav trygghet inför behandlingen och stimulerade fysioterapeuternas egen reflektion över patientens besvär och förbättrade möjligheten att finna en väg tillsammans.

När det specifikt gällde typologierna gjorde fysioterapeuterna olika erfarenheter, både att de var värdefulla och att de inte tillförde något nytt. När de var värdefulla bidrog de till att synliggöra patienternas problematik i ett bredare perspektiv. Bedömningen kunde sedan utgå från helheten. Typologierna hjälpte till att reda ut vilket förhållningssätt patienten hade till sin kropp och hur patienten tolkade sin smärta. När fysioterapeuterna tog ställning till om typologierna varit till nytta svarade de ofta med ord ur de givna beskrivningarna av de fyra typologierna. De använde ord som ambivalens, uppgivenhet och hopp eller hur patienterna ibland accepterat sin smärta och anpassat livet. Fysioterapeuterna beskrev att typologierna kunde ge en tydlig bild av var i accepterandeprocessen patienten befann sig.

\section{Betydelse av nyckelfrågorna för relationen mellan patient och fysioterapeut}

Denna huvudkategori hade inga underkategorier utan endast huvudkategori och dess koder.

Fysioterapeuterna redovisade att relationen förändrades positivt jämfört med tidigare erfarenhet av möten med patienter som med långvarig smärta. Skillnaderna handlade om djupet, stämningen och graden av ömsesidighet.

Djupet: Nyckelfrågorna beskrevs som ett respektfullt sätt att komma nära och att bygga upp förtroende, fördjupa relationen och göra den mer transparent vilket gjorde det möjligt att tala om känsliga frågor.

Stämningen: Stämningen beskrevs som positiv och alltifrån lugn, fokuserad och nyfiken till full av förväntan och intensitet.

Graden av ömsesidighet: Fysioterapeuternas respekt och intresse för patienten ökade, de beskrev också att de möttes med ökat förtroende och respekt från patienterna. Fysioterapeuterna blev tryggare i sina gensvar till patienterna och de blev inte så frustrerade av patienternas motstånd och attityder när de lärde känna dem bättre. Upplevelsen av jämbördighet nämndes och några uppgav att de kände sig mer delaktiga, i något fall också som ett team tillsammans med patienten. 


\section{Resultat av kvantifiering av kvalitativa koder}

I underkategorierna fanns det betydligt fler koder med positivt innehåll än med neutralt eller negativt (tabell 1). Till exempel uppfattade fysioterapeuterna att $\mathrm{i}$ $81 \%$ av kontakterna var patienternas "Omedelbara reaktioner" positiva till nyckelfrågorna (underkategori A1) och i 83 \% att deras "Förståelse av patienten" ökade (underkategori B1). För $64 \%$ av kontakterna angav fysioterapeuterna att "Frågornas inverkan på relationen" var positiv (kategori C).

\begin{tabular}{lcccc} 
Kategorier och underkategorier & Positiv & $\begin{array}{c}\text { Neutral// } \\
\text { negativ }\end{array}$ & Nollkod & $\begin{array}{c}\text { p- } \\
\text { värde* }\end{array}$ \\
\hline A Patienternas gensvar på nyckelfrågorna & & & & \\
A1 Omedelbar reaktion & $73(81 \%)$ & $16(18 \%)$ & $1(1 \%)$ & $<0.001$ \\
A2 Emotionell reaktion & $34(38 \%)$ & $9(10 \%)$ & $47(52 \%)$ & 0,015 \\
A3 Reflektion & $59(66 \%)$ & $30(33 \%)$ & $1(1 \%)$ & 0,018 \\
A4 Upplevelsen av förändring under samtalet & $12(13 \%)$ & $1(1 \%)$ & $77(86 \%)$ & 0,002 \\
& & & & \\
B Upplevd nytta och användbarhet av nyckelfrågor och typologier & & & \\
B1 Förstålse & $75(83 \%)$ & $12(13 \%)$ & $3(3 \%)$ & $<0.001$ \\
B2 Nyttan för bedömning och behandling & $68(76 \%)$ & $18(20 \%)$ & $4(4 \%)$ & $<0.001$ \\
B3 Typologiernas speciella bidrag & $61(68 \%)$ & $26(29 \%)$ & $3(3 \%)$ & 0,001 \\
& & & & \\
C Nyckelfrågornas betydelse för relationen (Positiv; & $58(64 \%)$ & $20(22 \%)$ & $12(13 \%)$ & $<0.001$ \\
gav djup, sinnesstämning, ömsesidighet, ospecificerad & & & & \\
förändring. & & & & \\
$\begin{array}{l}\text { Neutral/negativ (Påverkades inte, relationen var redan } \\
\text { bra) }\end{array}$ & & & \\
\hline (Skillnader mellan positiva och neutrala/negativ analyserades med hjälp av parade t-test (se analys - kvantitativt)). &
\end{tabular}

Tabell 1. Koderna från den kvalitativa analysen fördelade inom de olika kategorierna. Nollkod står för de patientmöten som inte hade svar inom berörd kategori. $(\mathrm{n}=90)$ 


\section{DISKUSSION}

\section{Resultatdiskussion}

\section{Fyra sammanlänkade arbeten}

Avhandlingsprojektet har genomförts i fyra sammanlänkande arbeten och med ett kroppsligt existentiellt perspektiv på långvarig och därmed svårbehandlad smärta. I detta perspektiv är kroppen både ett fysiskt faktum som ställer villkoren för livet och upplevelsen av ett kroppsligt jag i interaktion med omvärlden. Mitt antagande är att fysioterapeuten i gemen med detta perspektiv lättare kan leva sig in den smärtdrabbades upplevelser och tankar och därifrån finna vägar för samarbete, behandling och rehabilitering. Med avsiktliga kopplingar mellan de fyra arbetena har kunskaperna stegvis prövats och utvecklats. I korthet har avhandlingen gett insikt i hur det är att leva med smärta, kunskap som är en grund i mötet med patienter med smärta. Nyckelfrågorna har visat att det är möjligt för fysioterapeuter att föra kroppsligt existentiella samtal och att patienter förefaller uppleva dessa samtal positivt. Det reflekterande samtalet över hur det är att leva med smärta kan hjälpa till att finna rimliga och framkomliga vägar för behandlingen. Samtalen som nyckelfrågorna lett till har gett fysioterapeuterna förståelse för den enskilda patienten. Typologierna har möjliggjort för fysioterapeuter att se patienternas problematik ur ett vidare perspektiv.

I arbete I undersöktes upplevelsen av och sätten att förhålla sig till den värkande kroppen. Fyra aspekter av kroppsupplevelsen beskrevs och ur dessa urskildes fyra klart åtskilda typologier av förhållningssätt. I arbete II utvecklade och prövade en grupp fysioterapeuter nyckelfrågor som utforskar hur det är att leva med en kropp som värker. Frågorna togs fram ur intervjuguiden i det första arbetet. I arbete III undersöktes patienters svar på nyckelfrågorna, ställda av fysioterapeuter under kliniskt arbete, och de fyra aspekterna av kroppsupplevelse från första arbetet utgjorde begrepp för en deduktiv analys. Här fanns ingen anledning att gå tillbaka till en föregiven förutsättningslöshet utan i stället att bygga vidare på de tidigare kunskaperna. I arbete IV slutligen, prövades nyckelfrågor och typologier av en större grupp fysioterapeuter $\mathrm{i}$ primärvården och deras erfarenheter och den möjliga användbarheten av denna metod studerades. Den stora mängden skriftliga svar gav samtidigt 
ytterligare detaljering och konkretion åt kunskaperna om fysioterapeutens möte med patienter med långvarig smärta och om patientens upplevelser. Cirkulariteten i projektet där kunskaper och begrepp samtidigt utvecklades och prövades gav gradvis stadigare mark under fötterna. I det följande diskuterar jag resultatet av det samlade projektet; både de genomgående resultaten och de som härrör ur de enskilda studierna med betoning på sådant som har betydelse för den praktiska tillämpningen och för den teoretiska utvecklingen inom fysioterapin.

Sammanfattningsvis tydde resultaten på att kroppsmedvetenhet och kroppstillit var möjliga områden för fysioterapeuter att arbeta med för att stödja patienternas accepterandeprocess, vilken handlar om att integrera den värkande kroppen i identiteten. Det brott i livsloppet som smärtan gett upphov till kan bara överbryggas om kroppens faktum blir erkänt.

De sju nyckelfrågorna gav fysioterapeuter och patienter möjlighet att föra kliniska samtal om den värkande kroppen och dess roll i livet. Patienterna var villiga att delta i samtalen och gav ord för upplevelser på ett sätt som fysioterapeuterna inte hade förväntat sig. Samtalen ökade fysioterapeuternas förståelse för patienterna och deras bakgrund och ofta förbättrades relationen, samtidigt som det invanda och avgränsade behandlingsmandatet ibland ifrågasattes. Hos några patienter satte en process igång som föreföll vara mer genomgripande än enbart reflektionen. Nyckelfrågorna och typologierna, de senare en referensram för tolkning av förhållningssätt till en kropp som värker, kunde också vara till hjälp vid ställningstagande till behandling.

\section{Typologierna - Det biografiska perspektivet}

\section{Accepterandets väg - en process}

Typologierna i arbete I beskrev de intervjuades förhållningssätt till sin värkande kropp. Typologierna ger en bild av en möjlig eller teoretisk accepterandeprocess, från förnekande till den stoiska positionen att finna sig i sitt öde. Inledningsvis undersökte vi inte specifikt det biografiska perspektivet men det visade sig vara centralt i de följande studierna. I arbete II beskrev fysioterapeuterna att nyckelfrågorna $i$ sig själva föreföll starta en förändringsprocess. I arbete III reflekterade patienterna över sin kropp som 
barn, livet innan värk, och nu med värk, och ibland över hur framtiden skulle kunna gestalta sig. Patienternas svar på nyckelfrågorna beskrev hur den kroppsliga begränsningen och förändringen undan för undan kom att prägla deras liv och identitet. Detta benämner Corbin och Strauss (75) "Den biografiska tiden"; den levda kroppen som i ständig förändring - även utan sjukdom omdefinierar självuppfattningen för att personen ändå ska förbli densamma. I analysen framträdde kampen för att återfå det forna livet men också för att anpassa sig till de nya förutsättningarna. Patienterna reflekterade också över orsaken till sin smärta och om de skulle ha gjort samma val om de fått chans att leva om sitt liv. De beskrev det "biografiska brottet" (71) det vill säga händelser och tidpunkter när informanterna upplevde sin identitet som hotad och smärtan inte längre gick att tränga undan eller bedöva och förändring för de flesta blev ett måste.

Sedda i ljuset av biografin gav typologierna en ögonblicksbild genom att sammanfatta hur individen förhöll sig till sin värkande kropp vid ett specifikt tillfälle. Medan det i arbete I fanns de som föreföll ha fastnat i ett förnekande eller avståndstagande såg vi i arbete III i svaren vid det andra samtalet att hos sju av åtta patienter fanns en rörelse mot en högre grad av accepterande.

Typologierna beskriver teoretiskt en accepterandeprocess mot A (accepterat och anpassat sig) eller B (accepterat med aktiva copingstrategier), vilket inte alltid är fallet i verkliga livet. Vi tänker oss att startpunkten kan vara var som helst och även slutpunkten. Ambivalens (typologi C) eller konsekvent avståndstagande (typologi D) kan bli långvariga och kanske till och med bli bestående eller återkommande i perioder av ökad belastning eller skörhet.

Andra forskare beskriver processen som mer lagbunden. Bullington et al. (138) kallar den en väg från "kaos till ordning". Gullacksen (74) kallar stadierna "skeenden" och de innehåller alla ett då, ett nu och ett sedan. Den smärtdrabbade går från en önskan om att återställa livet som det en gång var via erkännande och insikt fram till inlärning/anpassning, för att slutligen leva med smärta med det underhållsarbete som livet fortsättningsvis kräver. Gullacksen undviker begreppet "accepterande" eftersom hon menar att kvinnorna i hennes studie inte accepterar sin situation utan tvingas leva med den. Till skillnad från Gullacksen menar vi att det finns ett möjligt accepterande, men inte nödvändigtvis av smärtan, utan framför allt av nödvändigheten att anpassa sig till sina förutsättningar. Det är den nivån av accepterande som typologierna av förhållningssätt till den värkande kroppen ytterst utgår ifrån. Mannerkorpi \& Kroksmark (17) beskrev hur kvinnor med fibromyalgi upplevde sina symtom. Dessa bildade mönster som liknar olika förhållningssätt till att leva med smärta; "att ge upp", "förtvivlan", "kämpa" eller "anpassa" (s. 
113). Om dessa mönster är föränderliga eller statiska kan enligt författarna av studien inte avgöras.

Vårt första arbete har en hel del likheter med Råheim \& Hålands (62) studie som gjordes ur ett livsvärldsperspektiv av kvinnor med långvarig smärta och fibromyalgi. De hade sin vetenskapliga uppmärksamhet på "den levda kroppen" och fann att kvinnorna förhöll sig på tre olika sätt; "i händerna på sin förrädiska kropp", "kämpa för att fly den förrädiska kroppen/ambivalens" och slutligen "måna om sin förrädiska kropp/coping" (s. 741). I vårt arbete kännetecknas typologierna av att de har en betoning på "den levda kroppen", och de har dessutom genom arbete IV prövats med lovande erfarenheter i fysioterapeutisk praktik. Ett vanligt fysioterapeutiskt mål är att patienten ska återerövra tilliten till kroppen, exempelvis efter ett benbrott, en hjärtinfarkt eller som här att våga röra sig trots smärta. Kroppsmedvetenhet är likaså ett fysioterapeutiskt fält där patienter får lära sig den svåra konsten att lyssna på kroppens signaler och bedöma hur aktiviteter kan anpassas för att tjäna hälsa och livskvalitet $(42,50,57,61,85,86,139-141)$. Att som fysioterapeut ha kunskap om hur patienten upplever och tänker om hur det är att leva med en kropp som värker är avgörande för att kunna möta patienten och planera behandling, men lika väsentlig är kunskapen om att detta är en process som går i olika tempo och med olika motstånd för olika individer. Endast så går det att urskilja den specifika patientens individuella väg och därmed undvika att stereotypt se henne som enbart en "smärtpatient".

Fysioterapeuterna i arbete IV beskrev att typologierna hjälpte till att få ett helhetsperspektiv på patientens problematik och att förstå var patienten befann sig i rehabiliteringsprocessen och vilket förhållningssätt de hade till sin värkande kropp.

\section{Kroppstillit och kroppsmedvetenhet gör det lättare att integrera den värkande kroppen i jaget}

Våra resultat talar för att accepterande är relaterat till personens kroppsmedvetenhet och kroppstillit. Typologi A innebär att man har accepterat och inte bråkar med sig själv om smärtan utan anpassar livet. I typologi B är kroppsmedvetenheten en förutsättning för accepterandet. Här beskrev informanterna sin utveckling från att tidigare varit mer eller mindre oförmögna att lyssna till kroppen, till att uppleva den som ett bollplank och en lärare. Ett 
sådant samspel är i sig ett framsteg och när samspelet väl upprättats ger det nya möjligheter att växa som människa och anledning att se framtiden an med optimism. Att vara lyhörd för kroppens röst och därmed komma förbi främlingskapet till kroppen stärker jaget (142). Man blir hel, trots smärta och funktionsnedsättning (138). Många med långvarig smärta har också beskrivit hur de upplevt sig försummade eller misstrodda av vårdpersonal $(36,143)$ vilket också kan leda till att de i sin tur misstror sina egna sinnen och sin förmåga att bedöma kroppens signaler och vad han eller hon tål. Johnsen \& Råheim beskriver dessa aspekter som avgörande för individens självrespekt (144).

I typologi $\mathrm{D}$, där blotta tanken på att acceptera sin värkande kropp avvisas, är kroppen avskild och omöjlig att förstå. Några av informanterna sa att de såg på sig själva utifrån, som om de var konstiga. De försökte rädda ansiktet genom att bära en mask av förnekelse (145). Toombs (69) har beskrivit hur den sjukes intuitiva uppfattning av att "jag kan" är skadad och därmed ändrad till "jag kan inte". Kroppen blir alienerad från jaget som försvagas. Själva varat, den "jag är" i grund och botten, innebär då en misstro mot de egna resurserna. Studier har visat att det finns ett samband mellan långvariga smärttillstånd/fysiska handikapp och minskad självkänsla (146). Detta anknyter till teorin om "kroppsjag" (147). Att inte lyssna till kroppens signaler är att överge sig själv. Merleau-Ponty säger att kroppens erfarenhet grundar jag-erfarenheten (66). Roxendal (148) säger: " ... med hjälp av begreppet 'kroppsjag' vill vi behålla den odelbara enheten människa med kropp-själ, 'body-mind' ... Särskilt i samband med långvariga sjukdomstillstånd kan symtom och funktionsbrister beskrivas som störningar i 'kroppsjaget'".

Att i fysioterapeutiskt arbete med individer med långvarig smärta ha möjlighet att benämna och arbeta med kroppstillit och kroppsmedvetenhet kan vara en väg för individen att förlikas med det han/hon drabbats av.

\section{Nyckelfrågorna}

\section{Nyckelfrågorna i det kliniska samtalet öppnar för att möta det svåra}

Om patienten får möjlighet att ingående berätta om de problem som fått honom/henne att söka fysioterapeut bereder detta vägen för dialog och samarbete, vilket i sin tur är förutsättning för att fysioterapeutens bedömning 
ska bli välgrundad och den eventuella behandlingen ändamålsenlig. Fysioterapeuten har huvudansvaret för att ett meningsfullt samtal uppstår (149, 150) och kan då skapa det som Daniel Stern (151) kallar "det intersubjektiva fältet". Enligt hans uppfattning kan ingen fullt ut förstå en annan människa men man kan anstränga sig för att förstå. I denna strävan och oundvikliga ofullkomlighet uppstår mötet. Den norska allmänläkaren Eli Berg (152) använde en snarlik term, "det kreativa mellanrummet" när hon i sin avhandling mer specifikt undersökte mötet mellan patient och läkare. Hennes utgångspunkt är den franske filosofen Emmanuel Levinas filosofi om "den andre"(152). Det kreativa mellanrummet är moraliskt och skapas i ett erkännande av, och i respekt för den andre, i detta sammanhang patienten, som person.

Fysioterapeuterna i både arbete II och IV erfor att nyckelfrågorna inspirerade till samtal som gav en både djup och bred bild av patienternas upplevelse och att patienterna var intresserade av att samtala med hjälp av nyckelfrågorna. Nyckelfrågorna är dock inte ett verktyg som bara genom att användas öppnar dörrarna till patienten. Vi bedömer att det krävs en vilja att skapa en förtroendefull relation, det vill säga "ett kreativt mellanrum" mellan terapeut och patient, för att frågorna ska uppnå sin fulla potential av engagemang och ömsesidighet. Vi tror också att det är nödvändigt att varje terapeut finner sitt personliga sätt att ställa frågorna. Det är frågornas specifika intentioner, inte de exakta formuleringarna, som är det väsentliga. Liknande överväganden gjorde Malterud (116) när hon diskuterade generaliserbarheten av sina nyckelfrågor ämnade för kvinnor med diffusa besvär.

När fysioterapeuterna genom svaren på nyckelfrågorna började reflektera över smärtans djupare innebörd, väcktes samtidigt frågor om hur man som behandlingsinriktad yrkesperson överhuvudtaget kan klara av att möta och bemöta ett lidande som går utöver det symptom man hoppas kunna behandla. Även om fysioterapeuterna allra mest uttryckte uppskattning över att nyckelfrågorna fick patienterna att öppna sig blev de ibland också frustrerade. De kunde känna sig maktlösa när de konfronterades med alltför mycket sorg och lidande. Några saknade därför frågor som specifikt utforskade positiva erfarenheter (Arbete II). När patienter ger uttryck för sina känslor underlättar detta fysioterapeutens förståelse av patientens problem och kan påverka resultatet av behandlingen positivt (153), men det väcker också försvar. Viktigt är att terapeuten inte känner sig trängd av det faktum att viktiga aspekter av patientens smärta ligger utanför fysioterapins räckvidd att behandla. 
Martin et al. (95) konstaterade att när fysioterapeuter ställdes inför patienters känslor, svarade de på en intellektuell nivå. Gard och Gyllensten (154) fann att fysioterapeuter i primärvården var medvetna om sina egna känslor såsom intresse och lust, medan nyfikenhet, sorg och ilska sällan erkändes, och avsky och avsmak aldrig nämndes. Att inte erkänna sina egna och/eller patientens känslor innebär ett avståndstagande vilket kan erbjuda terapeuter ett sätt att skydda sig själva, men det kan göra att patienten känner sig avvisad och bryter kontakten i mötet (155). Att erkänna för sig själv att en patient är krävande för mig som fysioterapeut gör det möjligt att planera arbetsdagen för att ha kraft nog till mötet. Rosbergs (61) informanter beskrev strategin att reglera antalet patienter med krävande problematik. Eftersom kliniska samtal inte sällan är utmanande är det mer ändamålsenligt att som Öien et al. (156) tala om svåra situationer, där terapeuten ser sig själv som en del av problemet $(48,150)$ än om svåra patienter. Några fysioterapeuter (arbete IV) beskrev att vissa samtal inte gav så mycket. Vad detta berodde på är svårt att säga men det kan vara tecken på just en "svår" situation. Att frågorna inte språkligt kommunicerar med alla patienter är en annan rimlig förklaring. De flesta av de fysioterapeuter som hade fler än ett samtal beskrev både givande och mindre givande konversationer.

Patienter bedömer fysioterapeuters förmåga att samtala med, relatera till och förstå människor som mycket värdefull (103). Både terapeuter och patienter tycker att det är viktigt att patientens egen kunskap kommer fram (105). Det finns redan en insikt bland fysioterapeuter att en bra relation till patienten och respekt för patientens egna resurser är förutsättningar för att behandlingen ska bli framgångsrik, ibland ännu viktigare än den specifika behandlingen (100). Den relationella aspekten, patientcentreringen (157), har en lång tradition inom allmänmedicinen men har inte fått samma tyngd i forskning och utbildning inom fysioterapin.

Vi uppfattar att nyckelfrågorna som utvecklats inom detta avhandlingsprojekt kan göra skillnad för det terapeutiska samtalet, och på längre sikt, för utvecklingen av fysioterapeuters kommunikativa och kroppsligt empatiska förmåga (54).

\section{Frågorna som behandling}

Genom att några av frågorna även tar upp smärtans möjliga symboliska betydelse - främst frågan; "Om smärtan kunde tala, vad skulle den säga?" - bjuds 
det in till ett tankeutbyte på metanivå mellan patient och fysioterapeut som kan få smärtupplevelsen att stå fram i nytt perspektiv. Denna möjlighet har använts av fysioterapeuter när de t.ex. använt målning, musik eller dans som alternativa vägar för patienter att uttrycka sin smärta (79). Nyckelfrågornas möjliga kreativa roll beskrivs inte explicit i Malteruds dialogmetod (114). Här är läkaren och patient inte på samma nivå. Patienten skulle, enligt Malterud, känna sig övergiven om läkaren i alltför stor utsträckning håller inne med sin kunskap under mötet. Det är möjligt att fysioterapeutyrket ger större frihet. Det rymmer mer tid och mer av kroppskontakt i en samarbetsanda som främjar jämställdhet i mötet. Det är mer naturligt för fysioterapeuten att ha kroppen som helhet $\mathrm{i}$ fokus. Patientens psykologiska försvar ses i muskler och andning och i förhållande till tyngdkraften och i kroppsspråket. I mötet hos fysioterapeuten blir Merleau-Pontys (66) begrepp "den levda kroppen" verkligt och synligt och den existentiella dimensionen av smärtan kan därmed också bli uppenbar för båda parter.

Nyckelfrågorna fick patienterna att öppna sina inre stängda dörrar och de känslor som väcktes var ibland smärtsamma. Intuitivt upplevde fysioterapeuterna att frågorna bidrog till förändring. Exempel gavs där fysioterapeuten efter patientmöten där nyckelfrågorna ställts, fått feedback från den remitterande läkaren som bekräftade den positiva utvecklingen. I sådana fall uppfattades nyckelfrågorna aktivt bidra till behandlingen. I $66 \%$ av samtalen i arbete IV uppfattade fysioterapeuterna att patienterna blev mer reflekterande. Nyckelfrågorna är öppna och utforskande och fysioterapeuten ställde dem utan att veta svaren. Bullington et al. (55) betonar att terapeutens förhållningssätt är en viktig faktor inom rehabiliteringen. Terapeuten ska låta patienten vara just så som han/hon är. Denna hållning kommer att hjälpa patienten att lära känna sig själv och relatera till andra och det stödjer läkningen. Enligt Charmaz (158) för individen en dialektisk dialog med sin kropp för att förstå situationen och anpassa sig till sjukdomen. Genom att använda nyckelfrågorna kan en sådan inre dialog externaliseras till det terapeutiska samtalet.

Förmodligen önskar alla som lider av långvarig smärta att den ska försvinna. I den smärtande upplevelsen beskrev en del av våra patienter (Arbetena I \& III) att smärtan även lett till viss positiv utveckling av livet. Man kan t.ex. ha fått andra värderingar, tagit sig själv mer på allvar, satt tydligare egna gränser och/eller kommit närmare sina vänner. Åsbring beskriver i sin kvalitativa studie (159) att individen då "överskrider sjukdomserfarenheten". I kliniskt arbete möter fysioterapeuter patienter inom ett brett spektrum av individuella sätt att 
rekonstruera sina liv efter att ha drabbats av smärta. Det är viktigt att låta patienterna berätta om sina erfarenheter, och detta kan vara avgörande för att terapeuten ska kunna planera lämplig behandling. När patientens tankar och erfarenheter utvecklas, kan man ibland inse att andra yrkesgrupper som psykologer, eller ett multiprofessionellt team (14) bättre skulle kunna möta patientens behov.

\section{Nyckelfrågorna - något för helhetsinriktade terapier?}

På olika sätt syftar helhetsinriktade fysioterapimodeller som Basal kroppskännedom (B-BAT), psykomotorisk fysioterapi (NPMP) och Feldenkraisbehandling till förbättrad kroppskännedom (160) och med olika betoningar är de inriktade på de kroppsligt-psykologiska och kroppsligtexistentiella sammanhangen. Det skulle vara av intresse att undersöka om nyckelfrågorna kan ha en positiv roll inom dessa behandlingsmodeller. Inom BBAT (144) betonas individens upplevelse av kroppen och målet är att uppnå större frihet och bättre balans i rörelse. Övningarna är inte bara övningar för den fysiska kroppen, utan även för den levda kroppen med sin bas både i nutid och i patientens personliga historia. I NPMP $(56,140)$ använder fysioterapeuten sina händer metodiskt för att få patienten medveten om möjlig hämning av andning och andra psykologiskt betingade lokala blockeringar och spänningar i kroppen. Feldenkrais är en pedagogisk metod som syftar till att förbättra den övergripande rörligheten i kroppen och som kan, förutom att ha en positiv inverkan på individers smärtlindring (161) också påverka kroppsmedvetenhet, livskvalitet och självkänsla $(162,163)$. En parallell och aktiv reflektion och dialog i ett biografiskt perspektiv vägledd av nyckelfrågorna skulle kunna tänkas stödja behandlingsprocessen.

I arbete I fann vi att kroppen som en aspekt av identiteten, kroppstillit, kroppskännedom, samt förståelse av smärtan var inblandade i upplevelsen av långvarig smärta. Arbete III gav indikationer på att nyckelfrågorna kan fånga upp förändringar som under ett behandlingsförlopp sker i dessa fyra aspekter av kroppsupplevelsen. Våra resultat ger därför anledning att undersöka om nyckelfrågorna kan vara till hjälp när eventuella effekter av helhetsinriktad fysioterapi ska utvärderas. 


\section{En professionell utmaning - det fysioterapeutiska mandatet}

Genom sina många år av arbete med patienter med långvarig smärta visste fysioterapeuterna i arbete II att individens hela liv har betydelse för upplevelsen av långvarig smärta och för förmågan att leva med den. Ändå behövde några påminna sig om och om igen om att det förhåller sig på det viset. Biomedicinska teorier har så länge dominerat att fysioterapeuterna tvivlade på sin moraliska rätt att fråga om livets påkänningar. När de prövade nyckelfrågorna sattes deras professionella mandat $i$ fråga. En sådan tvekan kan övergå i ett behandlingsbeslut när fysioterapeutens egen önskan och förväntan att hjälpa möter patientens begäran om snabb smärtlindring. Tillsammans kan de då söka förenklade lösningar som i realiteten inte är annat än sidospår $(5,164)$. Ambivalens och tvekan inför det sammansatta gäller inte bara fysioterapeuter utan den finns inom sjukvården som helhet. När det gäller långvarig smärta styr fortfarande akutmedicinska teorier ofta både valet av behandling och hur behandlingen organiseras (52). Genom att visa på ambivalensen hos de deltagande fysioterapeuterna, fångar studien sannolikt en viktig orsak till varför det är svårt att vidga det professionella mandatet från den fysiska kroppen till att också omfatta den levda kroppen. Första steget är ändå att inse att det traditionella fysioterapeutiska förhållningssättet är för smalt, med risk att patienten blir övergiven i sin upplevelse och får inadekvat behandling. Det finns grund att förmoda att detta är något som ganska ofta händer. För att sammanfatta frågan om professionella mandat hänvisar vi till den svenska fenomenologen Fredrik Svenaeus (165) och hans argumentation för att vårdpersonalen måste våga möta patientens tankar och känslor om sin sjukdom. Svenaeus skriver: "Att prata om hur det känns att lida av diabetes är inget psykologiskt eller etisk utanverk. Det är en integrerad del av diagnos och behandling. Att möta den sjuke är att möta hans värld och det sätt han bebor den på. Personens känslor, tankar och handlingar är här olika aspekter av ivärlden-varon som vårdens företrädare möter och måste arbeta med för att hela och bota - för att göra den sjukes i-världen-varo hemlik igen, eller i fallet av kronisk sjukdom mer hemlik". 


\section{Metoddiskussion}

\section{Kvalitativ metod}

Vi har använt kvalitativ metod i alla fyra arbetena, i det fjärde i kombination med kvantitativa beräkningar. Som framgått i redogörelsen för avhandlingens teoretiska perspektiv går det kroppsligt existentiella perspektivet hand $\mathrm{i}$ hand med ett fenomenologiskt perspektiv på kroppen. Även om endast det första arbetet har fenomenologi som uttalad metod, gäller det filosofiskt fenomenologiska perspektivet för alla.

De mer specifika metoderna har växlat med syftet för respektive arbete. I första arbetet var syftet att studera hur det är att leva med långvarig smärta. Upplevandet stod i centrum och det blev med denna fenomenologiska utgångspunkt självklart att också tillämpa en fenomenologisk metod (117).

Materialet var mycket omfattande och i detta fanns en risk att analysen inte skulle gå tillräckligt djupt och att viktiga enskildheter inte skulle uppmärksammas. Vi var tre forskare som gjorde analysen och vi hade under hela arbetets gång en ingående diskussion, utifrån materialet, om vad det innebär att leva med en kropp som värker. En viktig tillgång i EPP-metoden (117) är de synopser som utgör en kondensering av meningsinnehållet i varje informants svar. I dessa korta texter kunde vi få överblick av materialet.

I arbete II valdes fenomenografisk metod, en metod som studerar uppfattningar om erfarna fenomen. Vi undersökte fysioterapeuters uppfattningar om vad som hände när de använde nyckelfrågorna i samtal med sina patienter. Fysioterapeuterna samlades till fokusgrupper för att tillsammans reflektera över sina gjorda erfarenheter. När vi i arbete II undersökte hur de deltagande fysioterapeuterna uppfattade att deras patientmöten förändrades när de använde nyckelfrågorna, hade vi mycket få idéer om vad som skulle komma ut av gruppsamtalen. Vi hade planerat att göra en kvalitativ innehållsanalys men när vi bekantat oss med materialet anade vi de tre perspektiven; kunskapen om patienten, patienten i behandlingsprocessen och fysioterapeuten i relationen och valde fenomenografin, då vi bedömde att det skulle göra materialet mest rättvisa. Fokusgruppintervjuer är inte vanliga i fenomenografiska studier men har använts i några $(123,166)$. Ofta rekommenderas liksom i flertalet kvalitativa ansatser den semistrukturerade öppna intervjun $(110,127)$. De uppfattningar som formuleras i individuella intervjuer är dessutom, som alla uppfattningar, mer eller mindre kollektivt formade. I det avseendet råder bara en gradskillnad mellan grupp- och individintervju (167). 
I arbete III valdes en deduktiv kvalitativ metod, där begrepp från arbete I användes i analysen. Vi ville dels undersöka som patienternas svar på nyckelfrågorna och dels om begreppen kunde rekontextualiseras i detta material från ett kliniskt sammanhang. Teoretiskt hade en öppen kvalitativ analys av materialet varit ett alternativ men vi bedömde att vi redan var så färgade av arbete I att en sådan öppenhet inte var möjlig. Det var intressantare att undersöka om de redan utvecklade begreppen var gångbara. Begreppen visade sig genomsyra patienternas svar på nyckelfrågorna och dessutom bidra till att frilägga det biografiska perspektivet på patienternas långvariga smärta.

\section{Kvalitativ innehållsanalys med kvantifiering av koder}

I arbete IV använde vi Hickey \& Kipping:s metod (136) för kvalitativ innehållsanalys. Metoden modifierades något för att anpassas till att vi var två forskare som gjorde den kvalitativa analysen där Hickey \& Kipping föreslår tre. Metoden gav möjligheten att inkludera förhållandevis många fysioterapeuter och patientmöten och sedan möjligheten att kvantifiera koder. Vi bedömde oss därmed komma närmare ett svar på frågan om nyckelfrågorna och typologierna kunde vara till nytta för primärvårdens fysioterapeuter än om vi arbetat enbart kvalitativt. Resultatet visade ett brett spektrum av uppfattningar om vilket utbyte nyckelfrågor och typologier gav. Den kvantitativa delen av metoden gav oss möjlighet att beräkna i vilken omfattning de olika uppfattningarna förekom.

Som övergång från det kvalitativa resultatet till den kvantitativa analysen gjordes dikotomisering av det kvalitativa resultatet. Vi valde att låta de klart positiva koderna vara i en grupp och de neutrala och negativa i en gemensam grupp. Materialet hade stor övervikt av positiva koder, genom att föra samman neutrala och negativa koder ville vi visa att det även fanns patientmöten som inte var så givande. De neutrala och negativa svaren var mer kortfattade och inte så innehållsrika. Här kan man tänka sig att intervjuer av fysioterapeuterna skulle kunna ha gett bättre kunskap om när och varför arbetssättet inte fungerade. Det är troligt att en fysioterapeut som haft ett positivt möte vill dela med sig av detta och därför skrev ett mer innehållsrikt svar än den fysioterapeut som inte upplevde någon nytta av metoden.

En statistisk analys gjordes av det kvantifierade materialet. Viktigt var att veta om fysioterapeuternas svar hade några tydliga mönster, exempelvis att någon fysioterapeut alltid var positiv eller alltid negativ. Någon sådan tendens fanns 
inte. Inte heller skilde sig den fysioterapeut med två ID-nummer som provat metoden på tolv patienter från det övriga materialet. Vi fann att materialet var tillräckligt homogent för att påvisade resultat inte skulle bero på snedfördelning.

Ett alternativ för att få fram fysioterapeuternas uppfattningar av nyttan av nyckelfrågorna och typologierna vore en enkät. Enkäten är lättare att administrera både för forskarna och för informanterna. Kanske hade vi kunnat få in ytterligare patientmöten och på så sätt bygga våra beräkningar på en större grupp. Att göra en enkät innebär fasta svarsalternativ, vilket låser den som svarar till de på förhand tänkta möjligheterna. Forskaren har heller inte någon chans att förstå hur i detta fall fysioterapeuterna uppfattar frågan de svarar på. När de gäller de neutrala eller negativa svaren hade möjligtvis en enkät varit mer givande om vi differentierat även de negativa och neutrala alternativen. Vi bedömer dock som helhet att den valda metoden var den bästa utifrån våra forskningsfrågor och de givna förutsättningarna. Tydligheten $\mathrm{i}$ fysioterapeuternas beskrivningar talar för att resultatet bestämdes huvudsakligen av fysioterapeuternas användning av nyckelfrågorna och typologierna. Men vi anser att det är en intressant möjlighet för framtiden att göra en större, kvantitativ enkätstudie baserad på erfarenheter och resultat av den nuvarande. Genom detta skulle metoden bli en "mixed" (137) och slutsatser om den kliniska metodens tillämpbarhet skulle kunna dras med större säkerhet.

Ur ett genusperspektiv speglar vår första studie bäst den reella könsfördelningen bland dem som har långvarig smärta, en dryg tredjedel var män. I arbete II var alla sex fysioterapeuter kvinnor. I arbete III var alla fysioterapeuter och patienter kvinnor. I arbete IV var sju av 90 patienter män. I den svenska befolkningen beräknas 30,9\% av männen och 38,3\% av kvinnorna ha kronisk smärta (168). Männen i studien var underrepresenterade och svarade för endast $8 \%$, vilket är lågt även om man räknar in det faktum att män söker behandling för kronisk smärta i mindre omfattning än kvinnor gör. Finns det ett motstånd mot att erbjuda män samma möjlighet att tala om smärtans betydelse och kontakten med den egna kroppen? Ahlsén et al. (169) fann att mäns beskrivningar av sina symtom på långvarig smärta bestod huvudsakligen av objektiva fakta. I den studien drog författarna slutsatsen att vårdpersonal bör vara medvetna om att könsidentitet kan ha betydelse för beskrivningarna, men också för vad vi förväntar oss av män. Beskrivningarna av de sju samtal som fysioterapeuterna i arbete IV hade med manliga patienter skiljde sig dock inte, efter en ytlig jämförelse, från samtalen med kvinnliga patienter. 
Våra inklusionskriterier för alla arbeten förutsatte god förmåga att förstå och uttrycka sig på svenska. Det kreativa och symboliska inslagen i nyckelfrågorna gör dem sannolikt svårare att besvara för patienter från annan kulturell och språklig bakgrund, vilket uttrycktes av några fysioterapeuter i arbete II. Vidareutveckling av nyckelfrågorna för andra grupper i det svenska samhället och att pröva nyckelfrågorna med tolk vore möjliga och intressanta fortsättningar på projektet.

\section{Arbetets begränsningar}

En tydlig brist under forskningsprojektet har varit att nyckelfrågorna krävt goda kunskaper i svenska, samtidigt som en stor del av patienterna som söker fysioterapeut för långvarig smärta inte har tillräckliga kunskaper i svenska. Önskvärt hade också varit ett större antal manliga patienter i arbete II-IV.

\section{Implikationer för fortsatt forskning och utbildning}

Att genom studier undersöka möjligheterna att föra kroppsligt existentiella samtal, liknande de med nyckelfrågorna även med patienter som har annan språklig bakgrund än svenska vore intressant. Ett alternativ vore att använda tolk.

Genusfrågan har aktualiserats när det gäller användandet av nyckelfrågorna. Inga manliga patienter var delaktiga i arbete III. I arbete IV var endast sju av 90 patienter män. Det hade varit intressant att undersöka ytterligare på vilka grunder fysioterapeuterna i arbete IV valde ut patienterna. Fanns det ett motstånd mot att ställa frågorna till manliga patienter?

Typologierna utvecklades i en fenomenologisk analys och som sådana begreppsligt giltiga. Arbete IV ger en vink om överförbarheten och med de resultat och kunskaper vi nu har med oss förefaller det helt möjligt att omsätta de kvalitativa typologierna i ett frågeinstrument som skulle kunna prövas vad gäller intern konsistens och sedan bringas ned till ett antal generaliserbara 
kriterier för var och en av typologierna. Dessa validerade typologier skulle som resultat av en "mixed method" kunna användas vidare både i kliniskt arbete tillsammans med nyckelfrågorna och även i behandlingsforskning.

En jämförande studie av alternativa frågor skulle vara intressant och om möjligt också studera betydelsen av fysioterapeutens förmåga till närvaro och intresse i mötet.

De resultat som detta projekt givit talar för att fysioterapeuter skulle ha nytta av utbildning i att föra kroppsligt existentiella samtal med patienter med långvarig smärta. 


\section{KONKLUSION}

Fysioterapeuter har, genom forskning och praktiskt patientarbete, anammat uppfattningen att långvarig smärta är ett multidimensionellt tillstånd som påverkar en persons hela liv. Fysioterapeuter har efterfrågat anpassade behandlingsformer för patientgruppen $(55,170)$. Vi hoppas att resultaten som presenteras här kan bidra till att fysioterapeuter kan utveckla sin relation till patienten genom att de tillsammans undersöker innebörden och konsekvenserna av att leva med smärta. Detta kan också öka stringensen i arbetet. Metoden, sju nyckelfrågor tillsammans med referensramen för tolkning av förhållningssätten till smärta (de fyra typologierna), förefaller lätt att ta till sig för intresserade fysioterapeuter i icke specialiserad verksamhet.

Nyckelfrågorna gör patienten beredd att tillsammans med sin fysioterapeut reflektera över hur det är att leva med en kropp som värker. Frågorna har visat sig ge fysioterapeuterna ökad förståelse för sina patienter och i många fall en fördjupad relation.

Eftersom långvarig smärta utmanar och ibland drabbar kroppstilliten måste terapeutiska ansträngningar riktas, inte bara mot den objektiva kroppen med dess ben och muskler, utan också mot den kropp som ofta primärt utan ord förmedlar lidandet (55). Nyckelfrågorna kan då vara ett första steg.

Adekvat behandling i rätt tid skulle minska risken för att patienten fastnar i passiva copingstrategier $(145,171)$ och undvikandebeteende $(172,173)$. Förstärkning eller återupprättande av kroppsmedvetenhet och kroppstillit kan vara en möjlig väg framåt. Man kanske inte är perfekt, och livet kanske inte har motsvarat förhoppningarna, men med god kroppsmedvetenhet kan man anpassa sitt sätt att leva till sina fysiska förutsättningar. Integreringen av den värkande kroppen i identiteten innebär att bli hel igen, precis som den man är. Typologierna, vilka är anpassade efter den fysioterapeutiska praktiken, ger kunskap om hur patienten förhåller sig till sin värkande kropp, var i anpassningsprocessen som patienten befinner sig och vilket tempo eller motstånd som kan finnas i processen. Vi menar att ett accepterande är möjligt, kanske inte till smärtan, men till nödvändigheten att anpassa sig efter sina förutsättningar. Det är den nivån av accepterande som typologierna av förhållningssätt till den värkande kroppen ytterst utgår ifrån.

Tillsammans med sina patienter kan fysioterapeuter tidigare identifiera och besluta om vilka insatser som kan vara nödvändiga. Detta kombinerat med samarbete med andra professioner, inte minst allmänläkarna, skulle minska risken för upprepade behandlingar och rundvandring mellan terapeuter. Vi ser 
alltså potentiella fördelar inte bara för patienterna utan också för hälso- och sjukvården (174).

Arbetet med metoden belyser vikten av en utvidgning av fysioterapeutrollen. Utmaningen är att möta hela människan, som är sin levda kropp såväl som sin identitetskris buren av känslor som sorg och ilska. Detta kan kräva utbildning och professionell handledning, men sporrar också till att fullt ut utnyttja de möjligheter i mötet med patienten som den fysioterapeutiska yrkesrollen omfattar. 


\section{SAMMANFATTNING}

Bakgrund och syfte: Fysioterapeuter i primärvården möter, bedömer och behandlar patienter med långvarig benign muskuloskeletal smärta. Tillståndet är vanligt och men likafullt komplext. Syftet med detta avhandlingsarbete har varit att i ett kroppsligt existentiellt perspektiv utforska och begreppsliggöra upplevelsen av att leva med långvarig benign muskuloskeletal smärta samt att utifrån detta utveckla en metod för samtal och bedömning inom icke specialiserad fysioterapi.

Metoder: Arbete I var en intervjustudie med fenomenologisk ansats där vi undersökte hur individer med långvarig smärta upplevde sin kropp och sina besvär. Fyra aspekter av kroppsupplevelsen beskrevs och ur dessa urskildes fyra klart åtskilda typologier av förhållningssätt. I arbete II gjorde vi två gruppintervjuer med sex fysioterapeuter om deras erfarenheter av att i kliniskt arbete använda frågor - nyckelfrågor - ur frågeguiden i arbete I som givit särskilt rika svar. Utskrifterna av gruppintervjuerna analyserades med fenomenografisk ansats. I arbete III undersöktes patienters svar på nyckelfrågorna, ställda av fysioterapeuter under kliniskt arbete, och de fyra aspekterna av kroppsupplevelse från arbete I utgjorde begrepp för en deduktiv analys. I arbete IV slutligen prövades nyckelfrågorna och typologierna av en större grupp (31) fysioterapeuter i primärvården och deras erfarenheter och den möjliga användbarheten av metoden studerades. En kvalitativ innehållsanalys med beräkning av koder användes.

Resultat: Vi skapade fyra typologier av förhållningssätt till långvarig smärta: Acceptera sitt öde, acceptera genom aktiv förändring, befinna sig mellan acceptans och avståndstagande eller ta avstånd från sin värkande kropp. Dessa typologier byggdes upp av fyra aspekter av kroppsupplevelse: Kroppen som en aspekt av identiteten, kroppstillit, kroppsmedvetenhet samt förståelse av sin smärta. I arbete II visade det sig möjligt att tillsamman patient och fysioterapeut, med hjälp av nyckelfrågorna, föra ett kroppsligt existentiellt samtal. I samtalen lärde fysioterapeuten känna patienten som person, det föreföll som att en process inom patienten satte igång, samt att deras relation förändrades. Patienten var villig att samtala om sin värkande kropp och hade ord för detta. I studie III banade nyckelfrågorna väg för reflektioner om kropp, existens och biografi. De fyra aspekterna av kroppsupplevelse hade en central plats i patienternas beskrivningar. I arbete IV beskrev de deltagande sjukgymnasterna överlag positiva erfarenheter av att använda nyckelfrågor och typologier. Patienterna reflekterade, känslor väcktes och relationen och kommunikationen 
förbättrades ofta. Typologierna hjälpte till att få ett helhetsperspektiv på patientens problematik och att förstå var patienten befann sig i rehabiliteringsprocessen, vilket kunde vara värdefull vid bedömning och val av behandling.

Konklusion: Metoden, sju nyckelfrågor tillsammans med den erbjudna möjliga referensramen för tolkning av svaren (de fyra typologierna), förefaller lätt att ta till sig för intresserade fysioterapeuter $\mathrm{i}$ icke specialiserad verksamhet. Användandet av metoden belyser vikten av en utvidgning av fysioterapeutrollen. Utmaningen är att möta hela människan, som är sin levda kropp såväl som sin identitetskris buren av känslor som sorg och ilska. Detta kan sporra till att fullt ut utnyttja de möjligheter i mötet med patienten som den fysioterapeutiska yrkesrollen omfattar. 


\section{TACK}

Avhandlingen är ett resultat av frågan "hur är det att leva med en kropp som värker?" I utforskandet av svaret på frågan och dess följdfrågor har många varit vid min sida som jag vill tacka:

Först och främst vill jag tacka professor Carl Edvard Rudebeck som varit min följeslagare och vägledare i forskningens och filosofins värld under dessa år. Tack för all den tid du så generöst ägnat arbetet med avhandlingen, från början som huvudhandledare, men efter egen akademisk flytt till Tromsö universitet som bihandledare.

Jag vill också rikta ett varmt tack till docent Mats Foldevi som tog över som huvudhandledare och som med stort tålamod och klarsyn påpekat vikten av den logiska strukturen i mina arbeten. Tack också till bihandledare professor Madeleine Abrandt Dahlgren som med sitt skarpsinne sett styrkor och svagheter i mina metoder och resultatpresentationer. Tack också till docent Kajsa Johansson som under en period var god bihandledare och samtalspartner. Vännen, fysioterapeuten, läraren och medförfattaren Gabriele Biguet fick mig att inse den psykosomatiska sjukgymnastikens möjligheter och tillika forskningsområde.

Lars Brudin medförfattare, klinisk fysiolog och statistiker som med stor entusiasm och nyfikenhet har tagit del av projekten ända från start och deltagit aktivt $i$ arbete IV.

Ett stort varmt tack till alla mer än 160 patienter som villigt delat med sig av sina erfarenheter och vågat testat nytt.

Institutionen för medicin och hälsa, avdelningen för samhällsmedicin med allmänmedicin har varit min goda tillhörighet. Här vill jag tacka alla inom allmänmedicin för ert intresse för det kroppsligt existentiellas betydelse i mötet med patienten och den kunskap ni delat med er från ett vitt spektrum av forskningsområden.

Avhandlingsprojektet har ekonomiskt stöttats dels landstinget i Kalmar län som har givit mig möjlighet att inneha $25 \%$ doktorandbidrag och dels FORSS, Forskningsrådsnämnden i sydöstra Sverige som bidragit med forskningspengar. Ett stort tack också till min basenhet Samrehab med verksamhetschef Stefan Bragsjö och min närmaste arbetsplats Rehab där alla med Ulrika Blomé i spetsen, alltid mött mig med uppmuntran och intresse för avhandlingsprojektet, trots att jag ofta själv känt mig splittrad och besvärlig. Tack Marita Johansson för att du bl.a. höll reda på de 90 svaren. 
Eva Barath och Ulla Pettersson är kollegor som alltid funnits för mig. De har även tillsammans med fysioterapeut Kerstin Samuelsson och etnolog Johanna Övling korrekturläst och förbättrat avhandlingens manus.

Tack alla kollegor som hjälpt mig med arbetena: Eva Barath, Anelen Dahl, Annelie Winström-Christersson, Marlen Södergård Thorén, Margareta Roupe Wester, Gun Tranéus Köhler, Margareta Jacobsson, Birgit Junblad och alla de 31 fysioterapeuterna $\mathrm{i}$ arbete fyra. Forskarkollegan Irène Josephson, tack för gemensamt analysarbete, kloka synpunkter och hejarop. Tack mina vänner och förebilder, professor Ann Öhman och professor Maria Emmelin.

Utan Västerviks sjukhusbibliotek med Ulla Andersson och hennes medarbetare hade mitt liv som doktorand långt från universitetet varit betydligt svårare, så ett stort tack.

Socialt har mycket fått stå tillbaka, men inte "bokakademin" Monika Linder, Mai-Gret Fredriksson och Ulla Pettersson tillsammans med er har jag haft kontakt med god litteratur, innerliga diskussioner och god mat. "Badflickorna" Ylva Berg och Ingrid Arwedson har knutit upp prestationsångestens knutar med mycket skratt och ett och annat glas vin. Eva Mogard, tack för att du tagit med mig på äventyr.

Mest av allt vill jag tacka min familj, Lasse min kloka, varma livskamrat och våra tre härliga vuxna barn; Lisa med sin Nils, Johanna och Anton. Nu får jag mer tid till Arvid 4 år och Gustav, snart 3 år. 


\section{REFERENSER}

1. Bandura A. Self-efficacy; Toward a Unifying Theory of Behavioral Change. Psychological Review. 1977;84(2):191-213.

2. International Association for the Study of Pain. Classification of Chronic Pain. 2nd ed. Seattle: IASP Press; 1994.

3. Turk D, Melzack, R., editor. Handbook of Pain Assessment. 3 ed. New York: The Guilford Press; 2011.

4. Merskey H. BH, editor. Classification of chronic pain: descriptions of chronic pain syndromes and definitions of pain terms. . 2nd ed. Seattle: IASP Press; 1994.

5. Statens beredning för medicinsk utveckling, (The Swedish committee for medical development), SBU. Metoder för behandling av långvarig smärta (Methods for treatment of longstanding pain). 2006.

6. Gerdle B, Bjork J, Henriksson C, Bengtsson A. Prevalence of current and chronic pain and their influences upon work and healthcare-seeking: a population study. J Rheumatol. 2004;31(7):1399-406. Epub 2004/07/02.

7. Delgado P. Common pathways of depression and pain. . J Clin Psychiatry, Suppl 2004;65 (12):16-9.

8. Socialstyrelsen S, Svensk Läkarförening, Sveriges Kommuner och Landsting. National medical indications. [Indications for multimodal rehabilitation for long-lasting pain.] (in Swedish). Stockholm: 2011 2011:02. .

9. Andersson H. I. The course of non-malignant chronic pain: a 12-year followup of a cohort from the general population. Eur J Pain

2004 8:1.

10. Engel GL. The Need for a New Medical Model: A Challenge for Biomedicine. Science. 1977;196:129-36.

11. Gatchel R, Peng Y, Peters M, Fuchs P, Turk D. The biopsychosocial approach to chronic pain: scientific advances and future directions. Psychol Bull. 2007;133(4):581-624.

12. Turk DC., editor. Psychological approaches to pain management. A practitioner's handbook. . 2nd ed. New York: The Guilford Press.; 2002.

13. White P. Beyond the biomedical to the biopsychosocial: integrated medicine. In: White P, editor. Biopsychosocial medicine, an integrated approach to understand illness. Oxford: Oxford University press; 2005. p. 225-34. 
14. Statens beredning för medicinsk utveckling, (The Swedish committee for medical development), SBU. Rehabilitering vid långvarig smärta., En systematisk litteraturöversikt. Stockholm2010.

15. Kross E, Berman MG, Mischel W, Smith EE, Wager TD. Social rejection shares somatosensory representations with physical pain. Proc Natl Acad Sci U S A. 2011;108(15):6270-5. Epub 2011/03/30.

16. Becker N, Bondegaard Thomsen A, Olsen AK, Sjogren P, Bech P, Eriksen J. Pain epidemiology and health related quality of life in chronic non-malignant pain patients referred to a Danish multidisciplinary pain center. Pain. 1997;73(3):393-400. Epub 1998/02/20.

17. Mannerkorpi K, Kroksmark T, Ekdahl C. How patients with fibromyalgia experience their symptoms in everyday life. Physiother Res Int. 1999;4(2):11022. Epub 1999/08/13.

18. Turk DC, Dworkin RH, Revicki D, Harding G, Burke LB, Cella D, et al. Identifying important outcome domains for chronic pain clinical trials: an IMMPACT survey of people with pain. Pain. 2008;137(2):276-85. Epub 2007/10/17.

19. Dworkin RH, Turk DC, Farrar JT, Haythornthwaite JA, Jensen MP, Katz NP, et al. Core outcome measures for chronic pain clinical trials: IMMPACT recommendations. Pain. 2005;113(1-2):9-19. Epub 2004/12/29.

20. Turk DC, Dworkin RH, Allen RR, Bellamy N, Brandenburg N, Carr DB, et al. Core outcome domains for chronic pain clinical trials: IMMPACT recommendations. Pain. 2003;106(3):337-45. Epub 2003/12/09.

21. PainAustralia. Pain in Australia, working to prevent and manage pain. National Pain Strategy. 2011; Available from: http://www.painaustralia.org.au

22. Lundberg M, Larsson, M., Ostlund, H., Styf, J. Kinesiophobia among patients with musculoskeletal pain in primary healthcare. J Rehabil Med 2006;38(1):37-43.

23. Denison E, Asenlof P, Lindberg P. Self-efficacy, fear avoidance, and pain intensity as predictors of disability in subacute and chronic musculoskeletal pain patients in primary health care. Pain. 2004;111(3):245-52. Epub 2004/09/15. 24. Elton D, Stanley GV, Burrows GD. Self-esteem and chronic pain. J Psychosom Res. 1978;22(1):25-30.

25. Keefe FJ, Rumble ME, Scipio CD, Giordano LA, Perri LM. Psychological aspects of persistent pain: current state of the science. J Pain. 2004;5(4):195-211. 26. Sullivan MJl, Stanish, W. Waite, H., Sullivan, M. Tripp, D.A. Catastrophizing, pain, and disability in patients with soft- tissue injuries. Pain. 1998(77):253-60. 
27. Börsbo B, Gerdle, B., Peolsson, M. Impact of the interaction between selfefficacy, symptoms and catastrophising on disability, quality of life and health in with chronic pain patients. Disabil Rehabil. 2010;32(17):1387-96.

28. Gustafsson M, Ekholm J, Ohman A. From shame to respect: musculoskeletal pain patients' experience of a rehabilitation programme, a qualitative study. J Rehabil Med. 2004;36(3):97-103. Epub 2004/06/24.

29. Walker J, Sofaer B, Holloway I. The experience of chronic back pain: accounts of loss in those seeking help from pain clinics. Eur J Pain. 2006;10(3):199-207. Epub 2006/02/24.

30. Steihaug S, Ahlsen B, Malterud K. "I am allowed to be myself": women with chronic muscular pain being recognized. Scand J Public Health. 2002;30(4):2817. Epub 2003/04/12.

31. Sim J, Madden S. Illness experience in fibromyalgia syndrome: a metasynthesis of qualitative studies. Soc Sci Med. 2008;67(1):57-67. Epub 2008/04/22.

32. Toye F, Seers K, Allcock N, Briggs M, Carr E, Andrews J, et al. Patients' experiences of chronic non-malignant musculoskeletal pain: a qualitative systematic review. Br J Gen Pract. 2013;63(617):e829-41. Epub 2013/12/20.

33. Clarke K, Iphofen, R. Believing the patient with chronic pain: a review of literature. British Journal of Nursing. 2005;14(9):490-3.

34. Clarke K, Iphofen, R. A phenomenological hermeneutic study into unseen chronic pain. British Journal of Nursing. 2008;17(10):658-63.

35. Hellström O, Bullington J, Karlsson G, Lindqvist P, Mattsson B. A phenomenological study of fibromyalgia. Patient perspectives. Scandinavian Journal of Primary Health Care. 1999;17(1):11-6.

36. Johansson. EE., Hamberg K, Lindgren G, Westman G. "I've been crying my way"--qualitative analysis of a group of female patients' consultation experiences. Fam Pract 1996;13(6):498-503.

37. Werner A, Malterud K. It is hard work behaving as a credible patient: encounters between women with chronic pain and their doctors. Soc Sci Med 2003;57(8):1409-19.

38. Asbring P, Narvanen AL. Patient power and control: a study of women with uncertain illness trajectories. Qual Health Res. 2004;14(2):226-40. Epub 2004/02/11.

39. Undeland $M$, Malterud $K$. The fibromyalgia diagnosis: hardly helpful for the patients? A qualitative focus group study. Scand J Prim Health Care. 2007;25(4):250-5. Epub 2007/11/29.

40. Svensk beteendemedicinsk förening. www.svenskbeteendemedicin.se 2013. 
41. Denison E, Asenlof P. Beteendemedicinska tillämpningar i sjukgymnastik. Lund: STudentlitteratur AB; 2012.

42. Roxendal G. Body awareness therapy and the body awareness scale. Göteborg (Gothenburg): Göteborgs universitet (University of Gothenburg); 1985.

43. Gard G. Body awareness therapy for patients with fibromyalgia and chronic pain. Disabil Rehabil. 2005;27(12):725-8.

44. Thornquist E, Bunkan, B. Vad är psykomotorisk behandling? (What is psychomotor treatment?). Värnamo: Natur och Kultur; 1990.

45. Bunkan B. Psykomotrisk behandling (Psychomotor therapy). In: MeurleHallberg K., Gunnérius Å., editors. Kroppen som fysik - Kroppen som jag (The body as physics - the body as self). Falun: Dalarnas foskningsråd (The research committy in Dalakarlia, Sweden); 1990.

46. Bishop A, Foster NE. Do physical therapists in the United kingdom recognize psychosocial factors in patients with acute low back pain? Spine (Phila Pa 1976). 2005;30(11):1316-22. Epub 2005/06/02.

47. Demmelmaier I, Denison E, Lindberg P, Asenlof P. Physiotherapists' telephone consultations regarding back pain: a method to analyze screening of risk factors. Physiother Theory Pract. 2010;26(7):468-75. Epub 2010/07/24.

48. Nijs J, Roussel N, Paul van Wilgen C, Koke A, Smeets R. Thinking beyond muscles and joints: Therapists' and patients' attitudes and beliefs regarding chronic musculoskeletal pain are key to applying effective treatment. Man Ther. 2012. Epub 2013/01/01.

49. Turk DC, Wilson HD, Cahana A. Treatment of chronic non-cancer pain. Lancet. 2011;377(9784):2226-35. Epub 2011/06/28.

50. Bullington J. Embodiment and chronic pain: implications for rehabilitation practice. Health Care Anal. 2009;17(2):100-9. Epub 2009/02/03.

51. Nicholls DA, Gibson, B. E. The body and physiotherapy. Physiother Theory Pract. 2010 26(8):497-509. Epub 2010 Aug 26

52. Thunberg KA., Carlsson SG, Hallberg LR. Health care professionals' understanding of chronic pain: a grounded theory study. Scand J Caring Sci. 2001(15):99-105.

53. Sivik T, Theorell, T, editor. Psykosomatisk medicin. Lund: Studentlitteratur; 1995.

54. Rudebeck CE. The doctor, the patient and the body. Scand J Prim Health Care. 2000;18(1):4-8. Epub 2000/05/16.

55. Bullington J, Nordemar R, Nordemar K, Sjostrom-Flanagan C. Meaning out of chaos: a way to understand chronic pain. Scand J Caring Sci. 2003;17(4):32531. Epub 2003/11/25. 
56. Dragesund T, Raheim M. Norwegian psychomotor physiotherapy and patients with chronic pain: patients' perspective on body awareness. Physiother Theory Pract. 2008;24(4):243-54. Epub 2008/06/25.

57. Gyllensten AL, Skar L, Miller M, Gard G. Embodied identity -a deeper understanding of body awareness. Physiother Theory Pract. 2010;26(7):439-46. Epub 2010/07/24.

58. Lundberg M, Styf J, Bullington J. Experiences of moving with persistent pain--a qualitative study from a patient perspective. Physiother Theory Pract. 2007;23(4):199-209. Epub 2007/08/10.

59. Löfgren M., Ekholm J., Öhman A. 'A constant struggle': successful strategies of women in work despite fibromyalgia. Disabil Rehabil 2006;15(28):447-55.

60. Oien AM, Iversen S, Stensland P. Narratives of embodied experiences therapy processes in Norwegian psychomotor physiotherapy. Advances in Physiotherapy. 2007;9(1):31-9.

61. Rosberg S. Kropp, varande och mening i ett sjukgymnastiskt perspektiv (Body, being and meaning in a physiotherapeutic perspective). Gothenburg: Gothenburg University; 2000.

62. Råheim M., Håland W. Lived Experience of Chronic Pain and Fibromyalgia: Women's Stories From Daily Life. Qualitative Health Research 2006;16(6):74161.

63. Steihaug S, Malterud K. Stories about bodies: a narrative study on selfunderstanding and chronic pain. Scand J Prim Health Care. 2008;26(3):188-92. Epub 2008/07/09.

64. Thornquist E. Three voices in a Norwegian living room: an encounter from physiotherapy practice. Med Anthropol Q. 1997;11(3):324-51. Epub 1997/09/18. 65. Husserl E. The Crisis of European Scinces and Transcendental Phenomenology. Evanston: Northwestern University Press 1970.

66. Merleau Ponty M. Kroppens fenomenologi (Phenomenolgi of perception). Gothenburg: Daidalos; 1999.

67. Rudebeck C. General practice and dialogue of clinical practice. Umeå: Umeå University; 1992.

68. Gretland A. Den relasjonelle kroppen. Fysioterapi i psykisk helsearbeid. Bergen: Fagbokforlaget; 2007.

69. Toombs S. The meaning of illness. A phenomenological account of different perspectives of physicians and patient. London: Kluwer Academic Publishers; 1992.

70. Richt B. Mot en förändrad sjukdomsuppfattning (Towards a change of perception of illness). In: Liss P-E., Nordenfelt L., editors. Hälsa, sjukdom, 
Livskvalitet (Health, Disease and Quality of life). Linköping: Linköpings universitet; 1991.

71. Bury M. Chronic illness as biographical disruption. Sociology of Health \& Illness. 1982;4(2):167-82.

72. Winance M. Pain, disability and rehabilitation practices. A phenomenological perspective. Disabil Rehabil 2006;30(28):1109-18.

73. Charmaz K. The body identity and self: Adapting to impairment. The Sociological Quarterly. 1995;36(4):857-80.

74. Gullacksen AC, Lidbeck J. The life adjustment process in chronic pain: psychosocial assessment and clinical implications. Pain Res Manag. 2004;9(3):145-53.

75. Corbin J, Strauss A. Accompaniments of chronic illness: Change in body, self and biography and biographical time Research in the Sociology of Health Care. 1987;6:249-81.

76. Clarkson P., Mackewn J. Fritz Perls Dryden W., editor. London: Sage publications; 1993.

77. McCracken LM, Eccleston C, Bell L. Clinical assessment of behavioral coping responses: preliminary results from a brief inventory. Eur J Pain. 2005;9(1):69-78. Epub 2005/01/05.

78. Viane I, Crombez G, Eccleston C, Poppe C, Devulder J, Van Houdenhove B, et al. Acceptance of pain is an independent predictor of mental well-being in patients with chronic pain: empirical evidence and reappraisal. Pain. 2003;106(1-2):65-72. Epub 2003/10/29.

79. Bullington J, Sjöström-Flanagan C, Nordemar K, Nordemar R. From pain through chaos towards new meaning:Two case studies

The Arts in Psychotherapy 2005;32:261-74

80. Lundberg M. Kinesiophobia. Various aspects of moving with musculoskeletal pain. Göteborg: The Sahlgrenska Academy at Göteborg university; 2006.

81. Lundberg M, Hagberg K, Bullington J. My prosthesis as a part of me: a qualitative analysis of living with an osseointegrated prosthetic limb. Prosthet Orthot Int. 2011;35(2):207-14. Epub 2011/06/24.

82. Gyllensten A, Hansson L, Ekdahl C. Outcome of Basic Body Awareness Therapy. A randomised controlled study in psychiatric outpatient care. . Adv Physiother. 2003;5(4):179-90.

83. Gyllensten A, Ekdahl C, Hansson L. Long-term effectiveness of Basic Body Awareness Therapy in psychiatric outpatient care. A randomized controlled study Advances in Physiotherapy 2009; 11: 212. 2009;11(1):2-12. 
84. Gyllensten A, Hansson L, Ekdahl C. Patients experiences of Basic Body Awareness Therapy and the relationship with the physiotherapist. J Bodyw Mov Ther. 2003;3:173-83.

85. Klingberg-Olsson K, Lundgren, M., Lindström, I. Våga välja vad jag vill, Basal kroppskännedom och samtal i grupp. (Dare to choose what I want. Basic Awereness Therapy andpsychotherapy in a group.). Nordisk fysioterapi (Nordic Physiotherapy). 2000(4):133-44.

86. Mattsson M. Body Awareness applications in physiotherapy. Umeå, Sweden: Umeå University; 1998.

87. Johnsen-Wikene R, M. R. Feeling more in balance and grounded in one ' $s$ own body and life. Focus group interviews on experiences with Basic Body Awareness Therapy in psychiatric healthcare. Advances in Physiotherapy. 2010;12:166-74.

88. Klaber-Moffett J.A., Richardson PH. The influence of the physiotherapistpatient relationship on pain and disability. Physiotherapy Theory and Practice. 1997;13:89-96.

89. Abrand M. Learning physiotherapy: The impact of formal education and professional experience. Linköping: Linköpings universitet; 1997.

90. Linköpings, universitet. Programbeskrivning för sjukgymnastik vid Linköpings universitet [curriculum for physiotherapy education]. [webb page] Linköping: www.liu.se 2013 [updated 2013-03-22 ].

91. Gyllensten AL, Gard G, Salford E, Ekdahl C. Interaction between patient and physiotherapist: a qualitative study reflecting the physiotherapist's perspective. Physiotherapy Research International. 1999;4(2):89-109.

92. Tyni-Lenné R. Sjukgymnastik - fysioterapiprocess Sjukgymnasten (The physiotherapist). 1983(14):17-20.

93. Gyllensten AL. Basic Body Awareness. Lund: Lunds universitet (University of Lund); 2001.

94. Smith M, Ajjawi R, Johns M. Clinical reasoning in physiotherapy. In: HIggs J, Smith M, WEbb G, Skinner M, Croker A, editors. Contexts of physiotherapy practice. Sydney: Elsevier; 2009. p. 103-14.

95. Martin C, Sjösten A, Shephard K. The professional development of expert physical therapists in four areas of clinical practice. . Sjukgymnasten [Physiotherapist]. 1995;1(Spec. issue WCPT suppl.):4-11.

96. Thornquist E. Kommunikation i kliniken. Lund: Studentlitteratur; 2011.

97. Balint M. Läkaren, patienten och sjukdomen [The doctor, the patient and the illness). Lund: Studentlitteratur AB; 1978. 
98. Salinsky J. The Balint Movement world wide. Present state and future outlook, a brief history of Balint around the world. The American Journal of Psychoanalysis. 2002;62(4):327-35.

99. Holmström I. Gaining Professional Competence for Patient Encounters by Means of a New Understanding. Uppsala: Uppsala University; 2002.

100. Stenmar L, Nordholm LA. Swedish physical therapists' beliefs on what makes therapy work. Phys Ther. 1994;74(11):1034-9. Epub 1994/11/01.

101. Szybek k, Gard G, Linden J. The physiotherapist - patient relationship: applying a psychotherapy model. Physiotherapy Theory and Practice 2000;16(181-193).

102. Hall AM, Ferreira PH, Maher CG, Latimer J, Ferreira ML. The Influence of the Therapist-Patient Relationship on Treatment Outcome in Physical Rehabilitation: A Systematic Review. Physical Therapy. 2010;90(8):1099-110. 103. Kidd MO, Bond CH, Bell ML. Patients' perspectives of patient-centredness as important in musculoskeletal physiotherapy interactions: a qualitative study. Physiotherapy. 2011;97(2):154-62. Epub 2011/04/19.

104. Westman-Kumlin I., Kroksmark T. The first encounter. Physiotherapists' conceptions of establishing therapeutic relationships. Scandinavian Journal of Caring Science. 1992;1:37-44.

105. Wohlin Wottrich A, Stenstrom CH, Engardt M, Tham K, von Koch L. Characteristics of physiotherapy sessions from the patient's and therapist's perspective. Disabil Rehabil. 2004;26(20):1198-205. Epub 2004/09/17.

106. Thornquist E. Communication: what happens during the first encounter between patient and physiotherapist? Scand J Prim Health Care. 1990;8(3):1338. Epub 1990/09/01.

107. Biguet G. Psykomotorisk fysioterapi [Psychomotor physiotherapy]. In: Biguet G, Keskinen-Rosenqvist R, Levy-Berg A, editors. Att förstå kroppens budskap [To understand your body's messages]. Lund: Studentlitteratur; 2012. p. 232.

108. Josephson I. Utrymme för deltagande. Beslutsprocesser i möten mellan patienter med ospecifika ländryggsbesvär och sjukgymnaster inom primärvård [Space for participation. Decision-making processes in encounters between patients with non-specific low back pain and physiotherapists inprimary care ]. Jönköping: School of health sciences Jönköping; 2013.

109. Ekerholt K, Bergland, A. The first encounter with Norwegian psychomotor physiotherapy: Patients' experience, a basis for knowledge. Scandinavian Journal of Public Health. 2004;32(6):403-10.

110. Kvale S. Interviews. New York: Sage Publications Inc.; 1996. 
111. Roxendal G, Nordwall V. Tre BAS-skalor. [Three Body Awareness Scales]. Lund: Studentlitteratur 1997.

112. Clarkson P, Mackewn, J. Fritz Perls. Thousand Oaks: Sage Publications; 1993.

113. Andersen T. Reflekterande processer. Samtal och samtal om samtalen [Reflective processes. Talks and talk about talks]. Smedjebacken: Mareld; 2007. 114. Malterud K. Allmenpraktikerens möte med kvinnlige pasienter (The general practioner's encounter with female patients). Bergen Bergens universitet; 1990.

115. Malterud K. Strategies for empowering women's voices in the medical culture. Health Care Women Int. 1993;14(4):365-73. Epub 1993/07/01.

116. Malterud K. Key questions--a strategy for modifying clinical communication. Transforming tacit skills into a clinical method. Scand J Prim Health Care. 1994;12(2):121-7. Epub 1994/06/01.

117. Karlsson G. Psychological Qualitative Research from Phenomenological Perspective Stockholm: Almqvist \& Wiksell international; 1995.

118. Dahlgren L, Fallsberg, M. . Phenomenography as a qualitative approach in social pharmacy research. . J Soc Adm Pharm. 1991;8:150-6.

119. Marton F. Phenomenography: a research approach to investigating different understandings of reality. . J Thought. 1986;21::28-49.

120. Marton F. SL. Att Studera Omvärldsuppfattning: Två Bidrag Till Metodologin [A Study in Perception of Reality: Two Contributions to Methodology]. Göteborg: Institutionen för pedagogik, 1978.

121. Barnard A, McCosker, H., Gerber, R.,. Phenomenography: a qualitative research approach for exploring understanding in health care. . Qual Health Res. 1999;9:212-26.

122. Pang M, F. Two Faces of Variation: on continuity in the phenomenographic movement [1]. Scandinavian Journal of Educational Research. 2003;47(2):145. 123. Andén A, Andersson, SO., Rudebeck, CE. . Satisfaction is not all - patients' perceptions of outcome of general practice consultations, a qualitative study. ; 6: 43. BMC Fam Pract 2005;6:43.

124. Uljens M. Fenomenografi - forskning om uppfattningar. Lund: Studentlitteratur; 1989.

125. Stålsby L, C., Wahlström, R., Dall'Alba, G. Ways of experiencing asthma management. Scand J Prim Health Care. 1999;17:226-31.

126. Fridlund B, Lindgren EC, Ivarsson A, Jinhage BM, Bolse K, Flemme I, et al. Patients with implantable cardioverter-defibrillators and their conceptions of the life situation: a qualitative analysis. J Clin Nurs. 2000;9(1):37-45. Epub 2000/10/07. 
127. Karner A, Tingstrom P, Abrandt-Dahlgren M, Bergdahl B. Incentives for lifestyle changes in patients with coronary heart disease. J Adv Nurs. 2005;51(3):261-75. Epub 2005/07/22.

128. Wibeck V. Fokusgrupper [Focus-groups]. Lund Studentlitteratur; 2000.

129. Kreuger R. A CMA. Focus Groups a Practical Guide for Applied Research CA. 3rd ed. ed. Thousand Oaks: Sage; 2000.

130. Sjöström B, Dahlgren L. Applying phenomenography in nursing research. J Adv Nurs 2002;40(339-45).

131. Bowden J. Phenomenographic research, some methodological issues. . Nordisk Pedagogik (Nord Pedagogic). 1995;15:144-55.

132. Barnard A, McCosker, H., Gerber, R. . Phenomenography: a qualitative research approach for exploring understanding in health care. .Qual Health Res 1999;9:212-26.

133. Elo S, Kyngas H. The qualitative content analysis process. J Adv Nurs. 2008;62(1):107-15. Epub 2008/03/21.

134. Marshall C, Rossman, G. B. Designing Qualitative Research. Fourth ed. Thousand Oaks: Sage Publications 2006.

135. Crabtree BF, Miller, W.L, editor. Doing Qualitative Research. Newbury Park: SAGE Publications 1992.

136. Hickey G, Kipping, CJ. A multi-stage approach to the coding of data from open-ended questions. Nurse Researcher. 1996 4(1):81-91.

137. Tashakkori A, Teddlie, K. Handbook of mixed method in social and behavioural research. London: Sage Publications Inc.; 2003.

138. Bullington J, Nordemar R, Nordemar K, Sjostrom-Flanagan C. Meaning out of chaos: a way to understand chronic pain 2003.

139. Biguet G, Keskinen-Rosenqvist R, Levy-Berg A, editors. Att förstå kroppens buskap [To understand your body's messages]. Lund: Studentlitteratur; 2012.

140. Oien AM, Råheim M, Iversen S, Steihaug S. Self-perception as embodied knowledge -- changing processes for patients with chronic pain. Advances in Physiotherapy. 2009;11(3):121-9.

141. Steihaug S, Ahlsen B, Malterud K. From exercise and education to movement and interaction. Treatment groups in primary care for women with chronic muscular pain. Scandinavian Journal of Primary Health Care. 2001;19(4):249-54.

142. Roxendal G. Ett helhetsperspektiv- sjukgymnastik i framtiden (A holistic perspective-Physiotherapy in the future). Lund: Studentlitteratur; 1987.

143. Conrad P, Barker KK. The social construction of illness: key insights and policy implications. J Health Soc Behav. 2010;51 Suppl:S67-79. Epub 2010/12/22. 
144. Johnsen RW, Råheim, M. Feeling more in balance and grounded in one ' s own body and life. Focus group interviews on experiences with Basic Body Awareness Therapy in psychiatric healthcare. Advances in Physiotherapy. 2010(12):166-74.

145. Lazarus RS. Coping theory and research: past, present, and future. Psychosom Med. 1993;55(3):234-47.

146. Nosek MA, Hughes RB, Swedlund N, Taylor HB, Swank P. Self-esteem and women with disabilities. Soc Sci Med. 2003;56(8):1737-47.

147. Winberg A. Kroppsjag hos en grupp sjukhuspersonal mätt med BAS-hälsa och frågeformulär. (The body ego in a group of healthcare staff measured by the BAS-health and questionnaire.). Nordisk fysioterapi (Nordic Physiotherapy). 1999;3(4):174-86.

148. Roxendal G. Psykosomatiskt inriktad sjukgymnastik. (Psychosomatic Physiotherapy). In: Sivik T, Theorell, T, editor. Psykosomatisk Medicin In Psychosomatic Medicine. Lund: Studentlitteratur; 1995. p. 302-3.

149. Thornquist E. Examination and communication: a study of first encounters between patients and physiotherapists. Fam Pract. 1992;9(2):195-202. Epub 1992/06/01.

150. Trede F. Emancipatory physiotherapy practice. Physiother Theory Pract. 2012;28(6):466-73. Epub 2012/07/07.

151. Stern DN. Ögonblickets psykologi (The Present Moment of Psychotherapy and Everyday Life). Falkenberg: Natur och Kultur; 2005.

152. Berg E. Det skapende mellomrommet i mötet mellom pasient og lege (The creative intervening space in the meeting between patient and doctor) [Monography]. Tromsö: Universitetet i Tromsö; 2004.

153. Gard G., Lundvik G, A. Are emotions important for good interaction in treatment situations? . Physiother Theory Pract. 2004;20:107-19.

154. Gard G, Gyllensten Lundvik A. The importance of emotions in physiotherapeutic practice. . Phys Ther Rev. 2000;5:155-60.

155. Malterud K, Hollnagel H. Avoiding humiliation in the clinical encounter. Scand J Prim Health Care. 2007;25:69 -74.

156. Oien AM, Steihaug S, Iversen S, Raheim M. Communication as negotiation processes in long-term physiotherapy: a qualitative study. Scand J Caring Sci. 2011;25(1):53-61. Epub 2010/04/14.

157. Stewart M, Brown JB, Weston WW, McWhinney IR, McWilliam C, Freeman TR. Patient centred medicine - transforming the clinical method. London: Sage Publications; 1998.

158. Charmaz K. God days, bad days. The self in chronic illness and time. New Brunswick: Rutger University Press; 1991. 
159. Asbring P. Chronic illness - a disruption in life: identity-transformation among women with chronic fatigue syndrome and fibromyalgia. J Adv Nurs. 2001;34(3):312-9.

160. Mehling WE, Wrubel J, Daubenmier JJ, Price CJ, Kerr CE, Silow T, et al. Body Awareness: a phenomenological inquiry into the common ground of mind-body therapies. Philos Ethics Humanit Med. 2011;6:6. Epub 2011/04/09. 161. Connors KA, Pile C, Nichols ME. Does the Feldenkrais Method make a difference? An investigation into the use of outcome measurement tools for evaluating changes in clients. J Bodyw Mov Ther. 2011;15(4):446-52. Epub 2011/09/29.

162. Malmgren-Olsson EB, Branholm, I.B.,. A comparison between three physiotherapy approaches with regard to healthrelated factors in patients with non-specific musculoskeletal disorders. Disability and Rehabilitation 2002;24(6):308-17.

163. Ohman A, Astrom L, Malmgren-Olsson EB. Feldenkrais(R) therapy as group treatment for chronic pain--a qualitative evaluation. J Bodyw Mov Ther. 2011;15(2):153-61. Epub 2011/03/23.

164. Daykin A, Richardson B. Physiotherapists' pain beliefs and their influence on the management of patients with chronic low back pain. . Spine (Phila Pa 1976). 2004;29:783-95.

165. Svenaeus F. Sjukdomens Mening (The Meaning of Illness). Stockholm: Natur och Kultur 2003.

166. Anden A, Andersson SO, Rudebeck CE. To make a difference--how GPs conceive consultation outcomes. A phenomenographic study. BMC Fam Pract. 2009;10:4. Epub 2009/01/17.

167. Mishler EG. Research Interviewing, contest and narrative. First paperback ed. Cambridge, Massachusetts, USA: Harvard University Press; 1991.

168. Bergstrom G, Jensen IB, Bodin L, Linton SJ, Nygren AL, Carlsson SG. Reliability and factor structure of the Multidimensional Pain Inventory-Swedish Language Version (MPI-S). Pain. 1998;75(1):101-10.

169. Ahlsen B, Mengshoel AM, Solbraekke KN. Shelter from the storm; men with chronic pain and narratives from the rehabilitation clinic. Patient Educ Couns. 2012;89(2):316-20. Epub 2012/08/04.

170. Steen E, Haugli L. From pain to self-awareness--a qualitative analysis of the significance of group participation for persons with chronic musculoskeletal pain. Patient Educ Couns. 2001;42(1):35-46.

171. Covic T, Adamson B, Hough M. The impact of passive coping on rheumatoid arthritis pain. Rheumatology (Oxford). 2000;39(9):1027-30. 
172. Steen E, Haugli L. Generalised chronic musculoskeletal pain as a rational reaction to a life situation? Theor Med Bioeth. 2000;21(6):581-99. Epub 2001/02/24.

173. Vlaeyen JW, Linton SJ. Fear-avoidance and its consequences in chronic musculoskeletal pain: a state of the art. Pain. 2000;85(3):317-32. Epub 2000/04/27. 174. Bertakis K, Azari R. Patient-centered care is associated with decreased health care utilization. J Am Board Fam Med. 2011;24(3):229-39. 



\section{Intervjuguide till arbete I Öppningsfråga}

Bilaga 1.

Kan Du beskriva Dina besvär, jag tänker på de besvär som fick Dig att uppsöka sjukgymnast.

\section{Subjektiv förklaringsmodell}

Vad tror du att dina besvär kommer sig av?

\section{Besvärens betydelse för livet}

Hur var Ditt liv när Dina besvär uppkom?

Hur förändrade Dina besvär Ditt liv? Före/efter. Berätta.

Beskriv situationer/områden i Ditt liv där besvären inte har någon betydelse eller mycket liten betydelse.

Beskriv situationer/områden i Ditt liv där Dina besvär har stor betydelse.

Hur uppfattar Du att viktiga närstående tänker om dina problem?

Hur upplever du att du blivit bemött nu när du har dina besvär, jag tänker på vänner, försäkringskassa, vården, ja, jag tänker på dem du möter?

\section{Kroppsmedvetenhet/ kroppskontakt}

Försök just nu när du sitter här att tänka dig, dig själv utan kropp - vad blir kvar?

Beskriv hur du känner/upplever kroppen just nu och hur du brukar vara.(Pigg/trött, energifull/tom)

Beskriv hur det känns i din kropp när Du är glad/ledsen/arg o.s.v.

I vilken situationer kan du känna njutning utifrån någon fysisk aktivitet?

Litar Du på Din kropp? Kan Du beskriva det så konkret som möjligt.

Upplever du att din kropp är med dig eller emot dig?

Om smärtan kunde tala, vad skulle den säga?

Kan du minnas någon gång när kroppen förvånat dig?

\section{Förhållningssätt}

Vad har du kommit på är det bästa du själv kan göra för dina besvär?

Hur upplever Du att Du kan/inte kan påverka kroppen?

När Du tänker på Din kropp, hur upplever Du den i grunden? Den allmänna känslan som Din kropp ger Dig?

Är Du nöjd med Din kropp? Beskriv hur Du tänker.

Hur upplever Du hur Din kropp fungerar?

Berätta hur Du minns att Din kropp kändes/ upplevde din kropp när Du var barn. Fanns det aktiviteter som Du njöt av eller undvek?

Är du nöjd med din kropp?

\section{Allmän del}

Hur upplever Du Din hälsa?

Nu med facit i hand och du vet hur du mår idag, skulle du ha handla annorlunda om du fick chansen att göra om/leva om?

Har Dina besvär påverkat Din personlighet?

Är det något du vill tillägga? 



\section{Papers}

The articles associated with this thesis have been removed for copyright reasons. For more details about these see:

http://urn.kb.se/resolve?urn=urn:nbn:se:liu:diva-106748 